Meriellen Dias

ESTUDO DA DEGRADAÇÃO DA ENROFLOXACINA EM SOLUÇÃO AQUOSA POR MEIO DE PROCESSOS FOTO-OXIDATIVOS

São Paulo

2013 
Meriellen Dias

\section{ESTUDO DA DEGRADAÇÃO DA ENROFLOXACINA EM SOLUÇÃO AQUOSA POR MEIO DE PROCESSOS FOTO-OXIDATIVOS}

Dissertação apresentada à Escola Politécnica da Universidade de São Paulo para obtenção do título de Mestre em Engenharia

Área de concentração: Engenharia Química Orientador: Prof. Dr. Antonio Carlos Silva Costa Teixeira

São Paulo

2013 
Este exemplar foi revisado e alterado em relação à versão original, sob responsabilidade única do autor e com a anuência de seu orientador.

São Paulo, de junho de 2013.

Assinatura do autor

Assinatura do orientador

Dias, Meriellen

Estudo da degradação da enrofloxacina em solução aquosa por meio de processos foto-oxidativos / M. Dias. -- São Paulo, 2013.

89 p.

Dissertação (Mestrado) - Escola Politécnica da Universidade de São Paulo. Departamento de Engenharia Química.

1. Fármacos 2. Antibióticos 3. Foto-oxidação (Processos) 4. Compostos bio-orgânicos 5.Poluentes emergentes I. Universidade de São Paulo. Escola Politécnica. Departamento de Engenharia Química II. t. 
DEDICATÓRIA

A minha família. 


\section{AGRADECIMENTOS}

À minha família pelo apoio.

Ao meu orientador Prof. Dr. Antonio Carlos S. C. Teixeira, pelas discussões e contribuições e amizade.

À Profa. Dra. Carolina V. T. Giongo pelas contribuições ao trabalho.

À Profa. Dra. Maria Anita Mendes pelas contribuições ao trabalho.

Aos meus amigos do laboratório pelas conversas, o grande apoio e as risadas.

À Capes e ao CNPq pelo suporte financeiro. 


\section{RESUMO}

As tecnologias utilizadas em estações de tratamento de água e efluentes não são eficientes para a remoção total de resíduos farmacêuticos e os efeitos dessas substâncias sobre o meio ambiente e a saúde humana ainda não são bem conhecidos. No presente trabalho, estudou-se a degradação do antibiótico enrofloxacina (ENRO) por fotólise e pelo processo $\mathrm{H}_{2} \mathrm{O}_{2} / \mathrm{UV}$ na presença de compostos bio-orgânicos (BOS), que têm se apresentado como interessantes promotores da oxidação de poluentes. Os experimentos foram realizados em um reator fotoquímico tubular de imersão com fonte radiante (lâmpada de xenônio) concêntrica, operado em batelada com recirculação. Utilizaram-se concentrações iniciais de ENRO e de BOS iguais a $50 \mathrm{mg} \mathrm{L}^{-1}$ e $20 \mathrm{mg} \mathrm{L}^{-1}$, respectivamente. Para todos os pH mantidos constantes (3, 5,7 ou 9), a solução foi irradiada por 240 minutos. Os resultados indicam que o antibiótico não sofreu hidrólise em qualquer dos $\mathrm{pH}$ estudados em um período de 24 horas. Por sua vez, a fotólise da enrofloxacina mostrou-se eficiente somente na presença do composto bioorgânico CVT 230 (BOS C), com remoção de ENRO de quase 90\% em meio neutro ( $\mathrm{pH}$ 7). Resultados da literatura, associados a experimento realizado em meio anóxico, sugerem a participação de oxigênio singlete como principal espécie oxidante da enrofloxacina. Por outro lado, a degradação da ENRO pelo processo $\mathrm{H}_{2} \mathrm{O}_{2} / \mathrm{UV}$ apresentou remoção máxima do fármaco de $48 \% \mathrm{em} \mathrm{pH} 7$, o que sugere que a ação de oxigênio singlete e/ou radicais hidroxila não foi eficaz na presença de peróxido de hidrogênio. Portanto, O BOS C pode ser empregado como promotor no tratamento de águas e efluentes aquosos contaminados com enrofloxacina sob baixas potências radiantes ou em sistemas irradiados por luz solar. 


\begin{abstract}
The technologies used in water and wastewater treatment plants are not efficient for the total removal of pharmaceutical compounds whose effect to the environment and to human health are still not well known. In this work, the degradation of the antibiotic enrofloxacin (ENRO) was studied by photolysis and by the $\mathrm{H}_{2} \mathrm{O}_{2} / \mathrm{UV}$ process in the presence of bio-organic substances (BOS), which have been identified as interesting promoters of pollutant oxidation.The experiments were carried out in a tubular immersion photochemical reactor equipped with a concentric radiant source (xenon lamp), and operated in batch mode with recirulation. Initial ENRO and BOS concentrations of $50 \mathrm{mg} \mathrm{L}^{-1}$ and 20 $\mathrm{mg} \mathrm{L}^{-1}$ were used, respectively. The solution was irradiated for 240 minutes for all $\mathrm{pH}$ studied at constant values $(3,5,7$, and 9$)$. The results show that the antibiotic did not undergo hydrolysis at any $\mathrm{pH}$ after 24 hours. The photolysis of enrofloxacin showed to be efficient only in the presence of the bio-organic substance CVT 230 (BOS C), with almost 90\% ENRO removal in neutral solution $(\mathrm{pH} \mathrm{7).} \mathrm{Results} \mathrm{from}$ the literature, associated with an experiment carried out in anoxic conditions, suggest singlet oxygen as the main species responsible for enrofloxacin oxidation. On the other hand, ENRO degradation by the $\mathrm{H}_{2} \mathrm{O}_{2} / \mathrm{UV}$ process showed a maximum removal of $48 \%$ at $\mathrm{pH} 7$, suggesting that the action of singlet oxygen and/or hydroxyl radicals was not effective in the presence of hydrogen peroxide. BOS $C$ can therefore be used as an efficient promoter for the treatment of enrofloxacin-containing water and wastewater under low irradiant power or in solar-irradiated systems.
\end{abstract}




\section{LISTA DE FIGURAS}

Figura 1 : Rota de fármacos no meio ambiente (adaptado de HALLINGSORENSEN et al., 1998; HIRSCH et al., 1999; HEBERER, 2002).....................23

Figura 2 : Estrutura do ácido nalidíxico (LESHER et al., 1962)...........................25

Figura 3 : Estrutura do ácido pipemídico (WANG et al., 2010)...........................25

Figura 4 : Fórmula estrutural da enrofloxacina (MITCHELL, 2006)....................27

Figura 5 : Fragmento hipotético de uma molécula presente na fração solúvel orgânica extraída a partir do composto (QUALGLIOTTO et al., 2008)..................37

Figura 6 : Reator fotoquímico e equipamentos associados.................................45

Figura 7 : Esquema do equipamento experimental. ........................................45

Figura 8 : Espectro de emissão da lâmpada de xenônio (Xenon H27, modelo

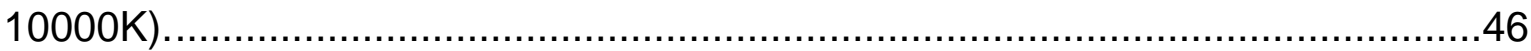

Figura 9 : Resultados do ensaio de hidrólise da enrofloxacina (ENRO) nos diferentes $\mathrm{pH}\left(3,5,7\right.$ e 9) com valores médios das duplicatas para $[E N R O]_{0}=25$ $\mathrm{mg} \mathrm{L}^{-1}$

Figura 10 : Resultados do ensaio de hidrólise da enrofloxacina (ENRO) nos diferentes $\mathrm{pH}\left(3,5,7\right.$ e 9) com valores médios das duplicatas para $[E N R O]_{0}=50$ $\mathrm{mg} \mathrm{L}^{-1}$

Figura 11 : Espectros de absorção UV-visível da enrofloxacina (ENRO) em solução aquosa à concentração de $5 \mathrm{mg} \mathrm{L}^{-1} \mathrm{em}$ diferentes $\mathrm{pH}(35,7$ e 9). Varredura de 190 a $450 \mathrm{~nm}$, com resolução de $1 \mathrm{~nm}$ e caminho ótico de $1 \mathrm{~cm} . . .53$

Figura 12 : Absorbância de enrofloxacina em solução aquosa em diferentes concentrações. Espectros de absorção medidos com resolução de $1 \mathrm{~nm}$.

Figura 13 : Distribuição espectral do coeficiente de absorção molar da enrofloxacina em solução aquosa em diferentes pH. Espectros de absorção medidos com resolução de $1 \mathrm{~nm}$ 
Figura 14 : Comportamento ácido-base da enrofloxacina (CHEMICALIZE, 2013).

Figura 15 : Obtenção experimental do pKa da enrofloxacina em solução aquosa.

Figura 16 : Estimativa de $\mathrm{pK}_{\mathrm{a}}$ para a enrofloxacina em solução aquosa. .58

Figura 17 : Tensão superficial dos compostos bio-orgânicos (BOS) a $25^{\circ} \mathrm{C} \mathrm{em} \mathrm{pH}$ 5.

Figura 18 : Resultados dos experimentos de fotólise da ENRO em pH 3 na ausência de BOS (experimento I), 5 (experimento II), 7 (experimento III) e 9 (experimento IV). Condições: [ENRO $]_{0}=50 \mathrm{mg} \mathrm{L}^{-1}$; lâmpada de xenônio de $35 \mathrm{~W}$; $25 \stackrel{\circ}{\circ} \mathrm{C}$. 62

Figura 19 : Resultados dos experimentos de fotólise da ENRO em pH 3, 5, 7 e 9, com indicação do erro experimental em cada tempo. Condições: [ENRO $]_{0}=50 \mathrm{mg}$ $\mathrm{L}^{-1}$; lâmpada de xenônio de $35 \mathrm{~W}$; $25 \stackrel{\circ}{\mathrm{C}}$

Figura 20 : Resultados dos experimentos de fotólise da ENRO em pH 3, 5, 7 e 9 na presença de BOS A (FORSUD). Condições: [ENRO $]_{0}=50 \mathrm{mg} \mathrm{L}^{-1} ;[\mathrm{BOS} \mathrm{A}]_{0}=20$ $\mathrm{mg} \mathrm{L}^{-1}$; lâmpada de xenônio de $35 \mathrm{~W} ; 25^{\circ} \mathrm{C}$.

Figura 21 : Resultados dos experimentos de fotólise da ENRO em pH 3, 5, 7 e 9 na presença de BOS B (CVDTFT110). Condições: [ENRO] $]_{0}=50 \mathrm{mg} \mathrm{L}^{-1}$; [BOS $\mathrm{B}]_{0}=20 \mathrm{mg} \mathrm{L}^{-1}$; lâmpada de xenônio de $35 \mathrm{~W} ; 25^{\circ} \mathrm{C}$.

Figura 22 : Resultados dos experimentos de fotólise da ENRO em pH 3, 5, 7 e 9 na presença de BOS C (CVT230). Condições: $[E N R O]_{0}=50 \mathrm{mg} \mathrm{L}^{-1}$; [BOS C $]_{0}=20$ $\mathrm{mg} \mathrm{L}^{-1}$; lâmpada de xenônio de $35 \mathrm{~W} ; 25^{\circ} \mathrm{C}$

Figura 23 : Resultados dos experimentos de fotólise da ENRO em pH 3, 5, 7 e 9 na presença de BOS C (CVT230) com, com indicação do erro experimental em cada tempo. Condições: $[E N R O]_{0}=50 \mathrm{mg} \mathrm{L}^{-1}$; $[\mathrm{BOS} \mathrm{C}]_{0}=20 \mathrm{mg} \mathrm{L}^{-1}$; lâmpada de xenônio de $35 \mathrm{~W} ; 25^{\circ} \mathrm{C}$ .66 
Figura 24 : Absorbância do composto bio-orgânico (BOS C, $20 \mathrm{mg} \mathrm{L}^{-1}$ ) em solução aquosa em diferentes $\mathrm{pH}(3,5,7$ e 9). Espectros de absorção medidos com resolução de $1 \mathrm{~nm}$.

Figura 25 : Absorbância da solução contendo enrofloxacina $\left(5 \mathrm{mg} \mathrm{L}^{-1}\right)$ e BOS C (20 $\left.\mathrm{mg} \mathrm{L}^{-1}\right)$ em solução aquosa em diferentes $\mathrm{pH}$ (3, 5, 7 e 9). Espectros de absorção medidos com resolução de $1 \mathrm{~nm}$.

Figura 26 : Experimento realizado em meio anóxico em pH 7 a $25^{\circ} \mathrm{C}$. Condições: $[E N R O]_{0}=50 \mathrm{mg} \mathrm{L}^{-1}$, [BOS $]_{0}=20 \mathrm{mg} \mathrm{L}^{-1}$; lâmpada de xenônio de $35 \mathrm{~W}$.

Figura 27 : Comparação entre o tratamento da solução aquosa contendo ENRO em pH 3 identificados com 1 e $1 \mathrm{~A}$ a $25^{\circ} \mathrm{C}$. Condições: [ENRO] $]_{0}=50 \mathrm{mg} \mathrm{L}$ ${ }^{1},\left[\mathrm{H}_{2} \mathrm{O}_{2}\right]_{0}=4,2 \mathrm{mg} \mathrm{L}^{-1}$, lâmpada de xenônio de $35 \mathrm{~W}$.

Figura 28 : Comparação entre o tratamento da solução aquosa contendo ENRO em pH 7 identificados com 2 e $2 \mathrm{~A}$ a $25^{\circ} \mathrm{C}$. Condições: [ENRO] $]_{0}=50 \mathrm{mg} \mathrm{L}-$ ${ }^{1},\left[\mathrm{H}_{2} \mathrm{O}_{2}\right]_{0}=4,2 \mathrm{mg} \mathrm{L}^{-1}$, lâmpada de xenônio de $35 \mathrm{~W}$.

Figura 29 : Comparação entre o tratamento da solução aquosa contendo ENRO em pH 3 identificados 3 e $3 \mathrm{~A}$ a $25^{\circ} \mathrm{C}$. Condições: $[E N R O]_{0}=50 \mathrm{mg} \mathrm{L}^{-1},\left[\mathrm{H}_{2} \mathrm{O}_{2}\right]_{0}=4,2$ $\mathrm{mg} \mathrm{L}^{-1}$, [BOS $]_{0}=20 \mathrm{mg} \mathrm{L}^{-1}$; lâmpada de xenônio de $35 \mathrm{~W}$

Figura 30 : Comparação entre o tratamento da solução aquosa contendo ENRO em pH 7 identificados 4 e $4 \mathrm{~A}$ a $25^{\circ} \mathrm{C}$. Condições: $[E N R O]_{0}=50 \mathrm{mg} \mathrm{L}^{-1},\left[\mathrm{H}_{2} \mathrm{O}_{2}\right]_{0}=4,2$ $\mathrm{mg} \mathrm{L}^{-1}$, [BOS $]_{0}=20 \mathrm{mg} \mathrm{L}^{-1}$; lâmpada de xenônio de $35 \mathrm{~W}$ .73

Figura 31 : Comparação entre os resultados dos experimentos $1 \mathrm{~A}$ e 3 (valores médios) realizados em $\mathrm{pH} 3$ a $25^{\circ} \mathrm{C}$. Condições: $[\mathrm{ENRO}]_{0}=50 \mathrm{mg} \mathrm{L}^{-1},\left[\mathrm{H}_{2} \mathrm{O}_{2}\right]_{0}=4,2$ $\mathrm{mg} \mathrm{L}^{-1}$, [BOS $]_{0}=20 \mathrm{mg} \mathrm{L}^{-1}$; lâmpada de xenônio de $35 \mathrm{~W}$.

Figura 32 : Comparação entre os resultados dos experimentos 2 e 4 (valores médios) realizados em pH 7 a $25^{\circ} \mathrm{C}$. Condições: $[\mathrm{ENRO}]_{0}=50 \mathrm{mg} \mathrm{L}^{-1},\left[\mathrm{H}_{2} \mathrm{O}_{2}\right]_{0}=4,2$ $\mathrm{mg} \mathrm{L}^{-1}$, [BOS $]_{0}=20 \mathrm{mg} \mathrm{L}^{-1}$; lâmpada de xenônio de $35 \mathrm{~W}$ .75

Figura 33 : Experimento realizado na presença de $\mathrm{H}_{2} \mathrm{O}_{2}$ sem radiação da solução aquosa contendo ENRO em $\mathrm{pH} 3$ a $25^{\circ} \mathrm{C}$. Condições: [ENRO] $]_{0}=50 \mathrm{mg} \mathrm{L}^{-1}$, $\left[\mathrm{H}_{2} \mathrm{O}_{2}\right]_{0}=4,2 \mathrm{mg} \mathrm{L}^{-1}$, $[\mathrm{BOS}]_{0}=20 \mathrm{mg} \mathrm{L}^{-1}$ 
Figura 34 : Experimento realizado na presença de $\mathrm{H}_{2} \mathrm{O}_{2}$ sem radiação da solução aquosa contendo ENRO em $\mathrm{pH} 7$ a $25^{\circ} \mathrm{C}$. Condições: [ENRO] $]_{0}=50 \mathrm{mg} \mathrm{L}^{-1}$, $\left[\mathrm{H}_{2} \mathrm{O}_{2}\right]_{0}=4,2 \mathrm{mg} \mathrm{L}^{-1},[\mathrm{BOS}]_{0}=20 \mathrm{mg} \mathrm{L}^{-1}$

Figura 35 : Comparação entre os diferentes processos de tratamento da solução aquosa contendo ENRO em pH 3 a $25^{\circ} \mathrm{C}$. Condições: $[E N R O]_{0}=50 \mathrm{mg} \mathrm{L}^{-1}$, $\left[\mathrm{H}_{2} \mathrm{O}_{2}\right]_{0}=4,2 \mathrm{mg} \mathrm{L}^{-1}$, [BOS $]_{0}=20 \mathrm{mg} \mathrm{L}^{-1}$; lâmpada de xenônio de $35 \mathrm{~W}$.

Figura 36 : Comparação entre os diferentes processos de tratamento da solução aquosa contendo ENRO em pH 7 a $25^{\circ} \mathrm{C}$. Condições: [ENRO] $]_{0}=50 \mathrm{mg} \mathrm{L}^{-1}$, $\left[\mathrm{H}_{2} \mathrm{O}_{2}\right]_{0}=4,2 \mathrm{mg} \mathrm{L}^{-1}$, [BOS $]_{0}=20 \mathrm{mg} \mathrm{L}^{-1}$; lâmpada de xenônio de $35 \mathrm{~W}$.

Figura 37 : Comparação entre as remoções de enrofloxacina obtidas ao final de 240 minutos para os diferentes processos de tratamento em $\mathrm{pH} 3$ a $25^{\circ} \mathrm{C}$. Condições: $[\mathrm{ENRO}]_{0}=50 \mathrm{mg} \mathrm{L}^{-1},\left[\mathrm{H}_{2} \mathrm{O}_{2}\right]_{0}=4,2 \mathrm{mg} \mathrm{L}^{-1}$, $[\mathrm{BOS}]_{0}=20 \mathrm{mg} \mathrm{L}^{-1}$; lâmpada de xenônio de $35 \mathrm{~W}$.

Figura 38 : Comparação entre as remoções de enrofloxacina obtidas ao final de 240 minutos para os diferentes processos de tratamento em $\mathrm{pH} 7$ a $25^{\circ} \mathrm{C}$. Condições: $[\mathrm{ENRO}]_{0}=50 \mathrm{mg} \mathrm{L}^{-1},\left[\mathrm{H}_{2} \mathrm{O}_{2}\right]_{0}=4,2 \mathrm{mg} \mathrm{L}^{-1}$, $[\mathrm{BOS}]_{0}=20 \mathrm{mg} \mathrm{L}^{-1}$; lâmpada de xenônio de $35 \mathrm{~W}$. 


\section{LISTA DE TABELAS}

Tabela 1 : Classificação dos processos oxidativos avançados (HUANG et al., 1993) 29

Tabela 2 : Potencial padrão de redução $(\mathrm{EPH})$ para vários oxidantes .30

Tabela 3 : Tipos e distribuição de grupos funcionais presentes nos BOS (PREVOT et al., 2008).

Tabela 4 : Características dos biosurfactantes (BOS) empregados neste trabalho. Adaptado de PREVOT et al. (2012) e de DITEXPA (2013).

Tabela 5 : Análise dos metais contidos no BOS C por ICP. Valores expressos em $\%$ mássica (SENESI, 2001)

Tabela 6 : Resultados dos ensaios de hidrólise da enrofloxacina (ENRO) nos diferentes valores de $\mathrm{pH}$.

Tabela 7 : Equações dos ajustes lineares de absorbância (abs) em $275 \mathrm{~nm}$ em função da concentração de ENRO a diferentes valores de $\mathrm{pH}$ e valores de $R^{2}$ correspondentes.

Tabela 8 : Resultados dos experimentos de fotólise de ENRO solução aquosa. .61

Tabela 9 : Resultados dos experimentos de degradação da enrofloxacina pelo processo $\mathrm{UV} / \mathrm{H}_{2} \mathrm{O}_{2}$ 


\section{LISTA DE SIGLAS}
Af
Alifáticos
$\operatorname{Ar}$
Aromáticos
BOS
Bio-organic substances (compostos bio-orgânicos)
$\mathrm{CMC}$
Concentação micelar critica
COT
Carbono orgânico total
$\mathrm{EPH}$
Eletrodo padrão de hidrogênio
ETE
Estação de tratamento de efluentes
ENRO
Enrofloxacina
EPR
Electron paramagnetic resonance
(ressonância paramagnética eletrônica)
FQ
Fluoroquinolonas
HPLC
High performance liquid chromatography
(cromatografia líquida de alta eficiência)
HS
Humic substances (substâncias húmicas)
$\mathrm{LH}$
Lipofílico-hidrofílico
MON
Matéria orgânica natural
POA
Processos oxidativos avançados
RMN
Espectrometria de ressonância magnética nuclear
RSU
Resíduos sólidos urbanos
UV
Ultravioleta 


\section{LISTA DE SÍMBOLOS}

$K_{a} \quad$ Constante de equilíbrio ácido-base

$\varepsilon \quad$ Coeficiente de absorção molar

$\mathrm{L} \mathrm{mol}^{-1} \mathrm{~cm}^{-1}$ 
SUMÁRIO

1. INTRODUÇÃO E JUSTIFICATIVA ........................................ 17

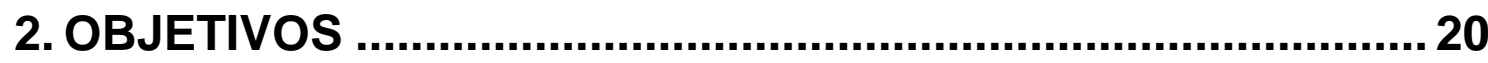

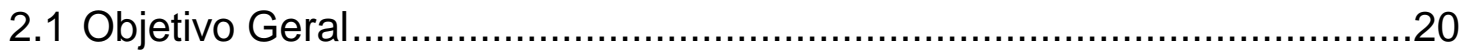

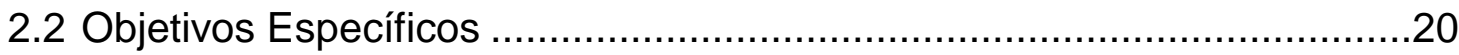

3. REVISÃO BIBLIOGRÁFICA............................................... 21

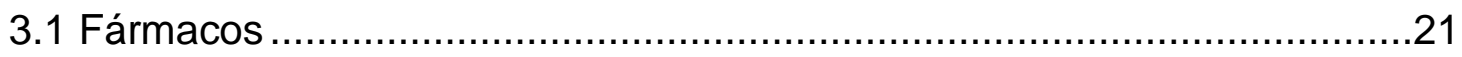

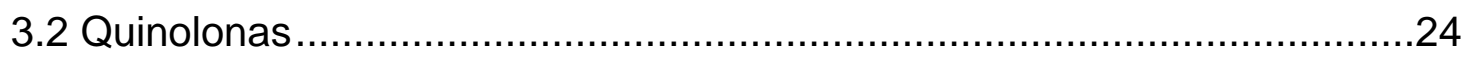

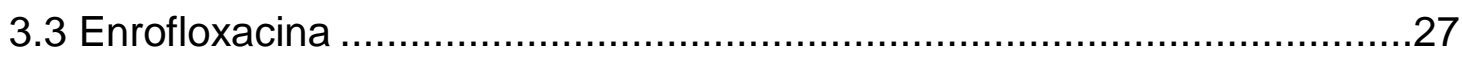

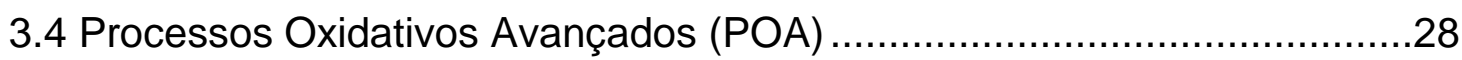

3.4.1 Fotólise com radiação ultravioleta (UV).......................................31

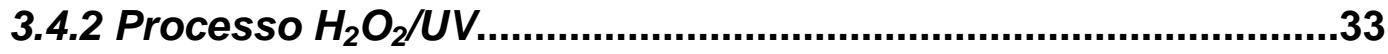

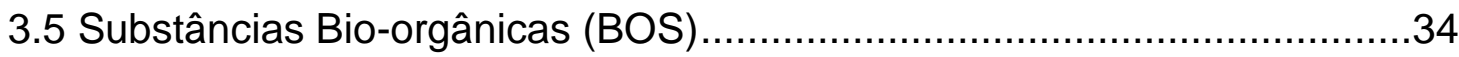

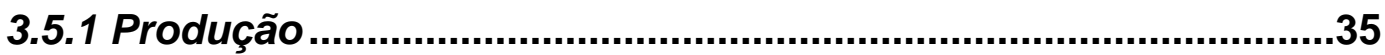

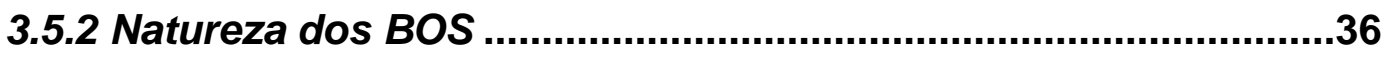

3.5.3 Propriedades dos BOS como surfactantes..................................37

3.5.4 Mecanismo de fotodegradação .....................................................38

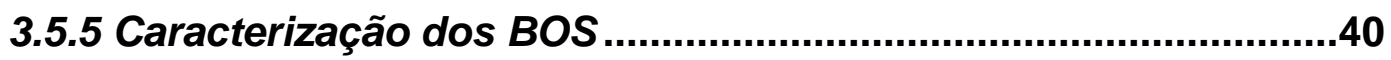

3.5.6 Vantagens e perspectivas do uso dos BOS ................................42

4. MATERIAIS E MÉTODOS ..................................................... 44

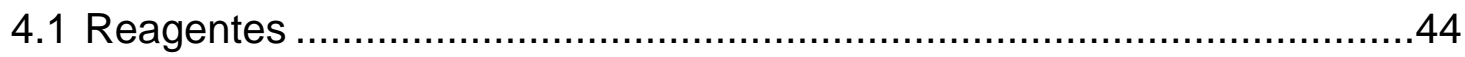

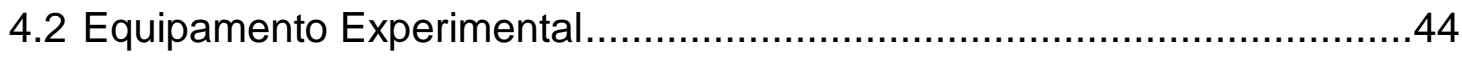

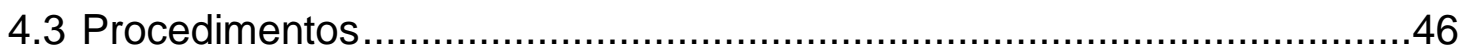


4.3.1 Ensaio de Hidrólise da Enrofloxacina em Solução Aquosa.......46

4.3.2 Estudo da Fotodegradação da Enrofloxacina

4.4 Medidas e Análises

4.4.1 pH e temperatura .......................................................................48

4.4.2 Espectrofotometria UV-visível .................................................48

4.4.3 Tensão superficial ....................................................................49

4.4.4 Cromatografia líquida de alta eficiência ...................................49

5. RESULTADOS E DISCUSSÃO ............................................ 51

5.1 Ensaio de Hidrólise da Enrofloxacina .................................................51

5.2 Avaliação Espectrofotométrica da Enrofloxacina em Solução Aquosa.....53

5.3 Obtenção do pKa de Soluções Aquosas de Enrofloxacina......................56

5.4 Medida de Tensão Superficial de Soluções de BOS ..............................59

5.5 Estudo da Degradação da Enrofloxacina por Fotólise em Solução Aquosa .60

5.6 Estudo da Degradação da Enrofloxacina pelo Processo $\mathrm{H}_{2} \mathrm{O}_{2} / \mathrm{UV}$...........70

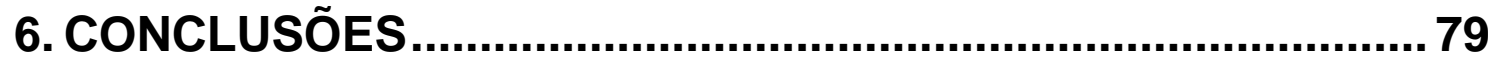

7. REFERÊNCIAS BIBLIOGRÁFICAS .......................................... 81 


\section{INTRODUÇÃO E JUSTIFICATIVA}

A crescente expansão demográfica e industrial observada nas últimas décadas trouxe como consequência o comprometimento da atmosfera, do solo e dos recursos hídricos. Neste sentido, um dos principais impactos ao meio ambiente é a poluição da água (MELO, 2009). A causa da poluição dos recursos hídricos é a disposição inadequada de esgotos domésticos e industriais nos mananciais, provocando diferentes impactos, em função dos variados compostos presentes no efluente tais como metais pesados e compostos orgânicos. Além destes, deve-se mencionar o descarte inadequado de medicamentos advindos das atividades humanas (doméstica e industrial), como também de resíduos provenientes da medicina veterinária. Essa contaminação resulta da excreção de metabólitos de fármacos, tanto por seres humanos quanto por animais e do descarte indevido destes compostos diretamente na rede de esgoto (ZUCCATO et al., 2005; ZUCCATO et al., 2006 apud EICKHOFF, HEINECK e SEIXAS, 2009). Este quadro é agravado uma vez que os fármacos são desenvolvidos para serem resistentes, mantendo suas propriedades químicas a fim de servir a um fim terapêutico específico. De modo geral, tais compostos, não são ou são apenas parcialmente removidos pelos processos convencionais de tratamento de esgoto em estações públicas e industriais de tratamento.

De acordo com PONEZl et al. (2007), o consumo mundial de fármacos é bastante significativo. Um exemplo disso pode ser visto na União Européia (EU), onde aproximadamente 3000 diferentes substâncias são usadas em medicamento para consumo humano como analgésicos e antiinflamatórios, anticoncepcionais, antibióticos, $\beta$-bloqueadores, reguladores de lipídios, e muitos outros, sendo que grande parte dessas substâncias é utilizada em medicamentos de uso veterinário. Independente da fonte geradora dos resíduos de fármacos, medicina humana, medicina veterinária ou indústrias, estes resíduos acabarão, em algum momento, se depositando no solo e nas águas, podendo influenciar a qualidade destas matrizes e a saúde ambiental como um todo (BILA e DEZOTTI, 2003). 
Em 2004 CARBALLA descreveu os processos oxidativos avançados (POA) como alternativa para remediação de efluentes contendo compostos não eliminados pelos processos biológicos, sendo os POA caracterizados por reações de oxidação intermediadas por radicais livres, tendo o radical hidroxila $(\cdot \mathrm{OH})$ como o principal entre eles, que são espécies altamente reativas e pouco seletiva.

Segundo GLAZE (1987), o radical hidroxila é formado a partir de oxidantes como $\mathrm{H}_{2} \mathrm{O}_{2}$ ou $\mathrm{O}_{3}$, sendo que a eficiência pode ser aumentada pela combinação com radiação ultravioleta (UV)/visível ou catalisadores (íons metálicos, semicondutores). Os POA têm apresentado grande potencial para tratamento de efluentes e muitas vantagens em relação a métodos convencionais de tratamento. É o caso do sistema $\mathrm{Fe}^{2+} / \mathrm{Fe}^{3+}-\mathrm{H}_{2} \mathrm{O}_{2}-\mathrm{UV}$-vis, comumente denominado foto-Fenton (BOSSMANN, 1998; LEGRINI, 1993; NASCIMENTO, 2004; NEYENS, 2003; PIGNATELLO, 2006).

A matéria orgânica natural (MON) tem propriedades que afetam de muitas maneiras o destino dos poluentes orgânicos e da matéria inorgânica presente no meio ambiente. A MON é constituída por substâncias poliméricas que contêm carbonos em cadeias alifáticas e anéis aromáticos, com substituintes diversos como grupos fenol, éter, aminas e amidas (MONTONERI, 2009). Com o isolamento desta matéria orgânica foram obtidas substâncias classificadas como compostos bio-orgânicos (BOS), cuja produção é realizada a partir do isolamento da matéria orgânica do lixo submetida a compostagem.

Estes compostos bio-orgânicos compreendem compostos de origem biológica, com composição química muito complexa e distribuição de massas molares cuja caracterização é matéria de grande controvérsia (BAALOUSHA et al., 2006). Os BOS apresentam-se como alternativa interessante quando utilizados como promotores do tratamento de efluentes contendo poluentes tais como compostos farmacêuticos (MONTONERI et al., 2009).

Neste trabalho é estudada a degradação do antibiótico enrofloxacina (ENRO), intensamente utilizado a partir da década de 1970 e que tem sido detectado em ambientes aquáticos, como mostram vários estudos (CUNHA et al., 2009; GUINEA et al., 2010; STURINI et al., 2010; YANG LI et al., 2011 ). A degradação da ENRO é realizada por meio de processos foto-oxidativos, em 
particular o processo de fotólise e o processo $\mathrm{H}_{2} \mathrm{O}_{2} / \mathrm{UV}$, buscando-se avaliar o efeito do composto bio-orgânico (BOS) na degradação do fármaco nos processos estudados. 


\section{OBJETIVOS}

\subsection{Objetivo Geral}

O objetivo geral deste trabalho é avaliar a degradação do composto farmacêutico enrofloxacina em solução aquosa, por meio de processos fotoquímicos, buscando-se avaliar o comportamento desses processos na presença de compostos bio-orgânico (BOS) provenientes de resíduos sólidos urbanos.

2.2 Objetivos Específicos

- Caracterizar soluções aquosas de enrofloxacina quanto à estabilidade e propriedades ópticas em diferentes $\mathrm{pH}$;

- Avaliar a degradação do antibiótico enrofloxacina em solução aquosa por fotólise e pelo processo $\mathrm{H}_{2} \mathrm{O}_{2} / \mathrm{UV}$, avaliando o efeito do $\mathrm{pH}$ e da presença de compostos bio-orgânicos (BOS), sob radiação UV-visível obtida por lâmpada de xenônio;

- Caracterizar soluções aquosas de enrofloxacina antes e após o tratamento quanto à degradação do antibiótico, procurando explicar o papel dos BOS na degradação da enrofloxacina em diferentes condições. 


\section{REVISÃO BIBLIOGRÁFICA}

\subsection{Fármacos}

Nas últimas décadas, tem sido detectado um elevado número de produtos farmacêuticos em águas subterrâneas, águas superficiais e mesmo na água para consumo humano. Essa contaminação é proveniente do esgoto doméstico, bem como da atividade da indústria químico-farmacêutica, da agropecuária e da piscicultura (MELLO et al., 2009).

O termo fármaco é a denominação genérica para compostos utilizados tanto na medicina humana como veterinária (ALMEIDA, 2005). Estas substâncias apresentam moderada solubilidade em água, sendo biologicamente ativas e lipofílicas e hidofílicas (ALMEIDA, 2005). As moléculas são absorvidas e metabolizadas parcialmente e então excretadas pelo organismo. Medicamentos modernos apresentam maior eficiência quando metabolizados por órgãos como fígado ou rins, só assim promovendo seus efeitos farmacológicos (REGITANO, 2010).

$\mathrm{Na}$ década de 1970, a presença de fármacos em ambientes aquáticos começou a ser observada e, desde então, diversos estudos têm sido realizados e revelam a presença de resíduos de fármacos em corpos d'água em várias partes do mundo (MELLO et al., 2009).

Antibióticos constituem um grupo de fármacos destinado ao tratamento humano e veterinário, baseado em infecções causadas por fungos e bactérias. Diversos antibióticos são derivados completamente ou parcialmente de certos microorganismos, outros são sintéticos (IKEHATA et al., 2006). Os antibióticos são amplamente utilizados em todo o mundo e seu consumo anual é estimado entre 100.000 e 200.000 toneladas (KÜMMERER, 2003). O Brasil é um dos maiores consumidores de medicamentos, assim como os EUA, onde são produzidas mais de 20.000 toneladas de antibióticos por ano, sendo $60 \%$ destinadas ao uso humano e $40 \%$ para uso veterinário (BROWN et al., 2006). 
$\mathrm{Na}$ Alemanha, o consumo anual de antibióticos na medicina humana foi estimado em aproximadamente 400 toneladas, dois terços dos quais são excretados no sistema de esgotos como via de emissão (GARTISER et al., 2007). Cerca de 50.000 drogas foram registradas na Alemanha para uso humano, compreendendo aproximadamente 900 substâncias ativas diferentes (KÜMMERER, 2001). Na China, levantamentos indicam que mais de $70 \%$ das drogas prescritas são antibióticos, quando comparadas aos 30\% nos países ocidentais (GULKOWSKA et al., 2007). Em 2011, o consumo anual de antibióticos no Brasil foi de 94,7 milhões de unidades (ANVISA, 2011). Estes são os compostos farmacêuticos mais encontrados em ambientes aquáticos, pois são desenvolvidos para adquirir resistência, mantendo suas propriedades químicas, sendo assim apenas parcialmente degradados em estações de tratamento biológico, devido a sua natureza.

Devido ao alto consumo de fármacos, um número cada vez maior de estudos abrangendo a entrada destes compostos no meio ambiente tem sido observado, como dados sobre a ocorrência, destino e os efeitos por eles causados. O comportamento dos fármacos e de seus metabólitos no ambiente aquático ainda não é bem conhecido. A baixa volatilidade desses compostos indica que sua distribuição no meio ambiente ocorrerá principalmente por via aquática, mas também através da cadeia alimentar e disposição no solo (BILA e DEZOTTI, 2003).

A principal rota de entrada de resíduos de fármacos no ambiente é o lançamento de esgotos domésticos, tratados ou não, em cursos de água. No entanto, também devem ser considerados os efluentes de indústrias farmacêuticas, efluentes rurais, a presença de fármacos no esterco animal utilizado para adubação de solos e a disposição inadequada de fármacos após expiração do prazo de validade (BILA e DEZOTTI, 2003; HEBERER, 2002). A Figura 1 mostra esquematicamente a introdução de produtos farmacêuticos no ambiente aquático (HALLING-SORENSEN et al., 1998; HIRSCH et al., 1999; HEBERER, 2002).

Os antibióticos são um dos grupos mais importantes de produtos farmacêuticos (KÜMMERER, 2009a). A presença destes poluentes no ambiente aquático pressupõe um risco potencial para a saúde dos seres vivos, 
uma vez que se verificou que algumas drogas podem favorecer 0 desenvolvimento de cepas multi-resistentes de bactérias patogênicas (GUINEA et al., 2010), afetando, entre muitos outros aspectos, o sistema endócrino dos peixes e, até mesmo, exercendo efeitos tóxicos sobre as algas e invertebrados (GUINEA et al., 2010).

A rota dos fármacos no meio ambiente é pouco conhecida, mas sua ocorrência pode apresentar efeitos adversos em organismos terrestres e aquáticos. Tais efeitos ocorrem em qualquer nível da hierarquia biológica, como célula, órgãos, organismos, população e até mesmo ecossistemas. Segundo JORGENSEN et al. (2000), alguns desses efeitos podem ser observados em concentrações na ordem de $n g \mathrm{~L}^{-1}$.

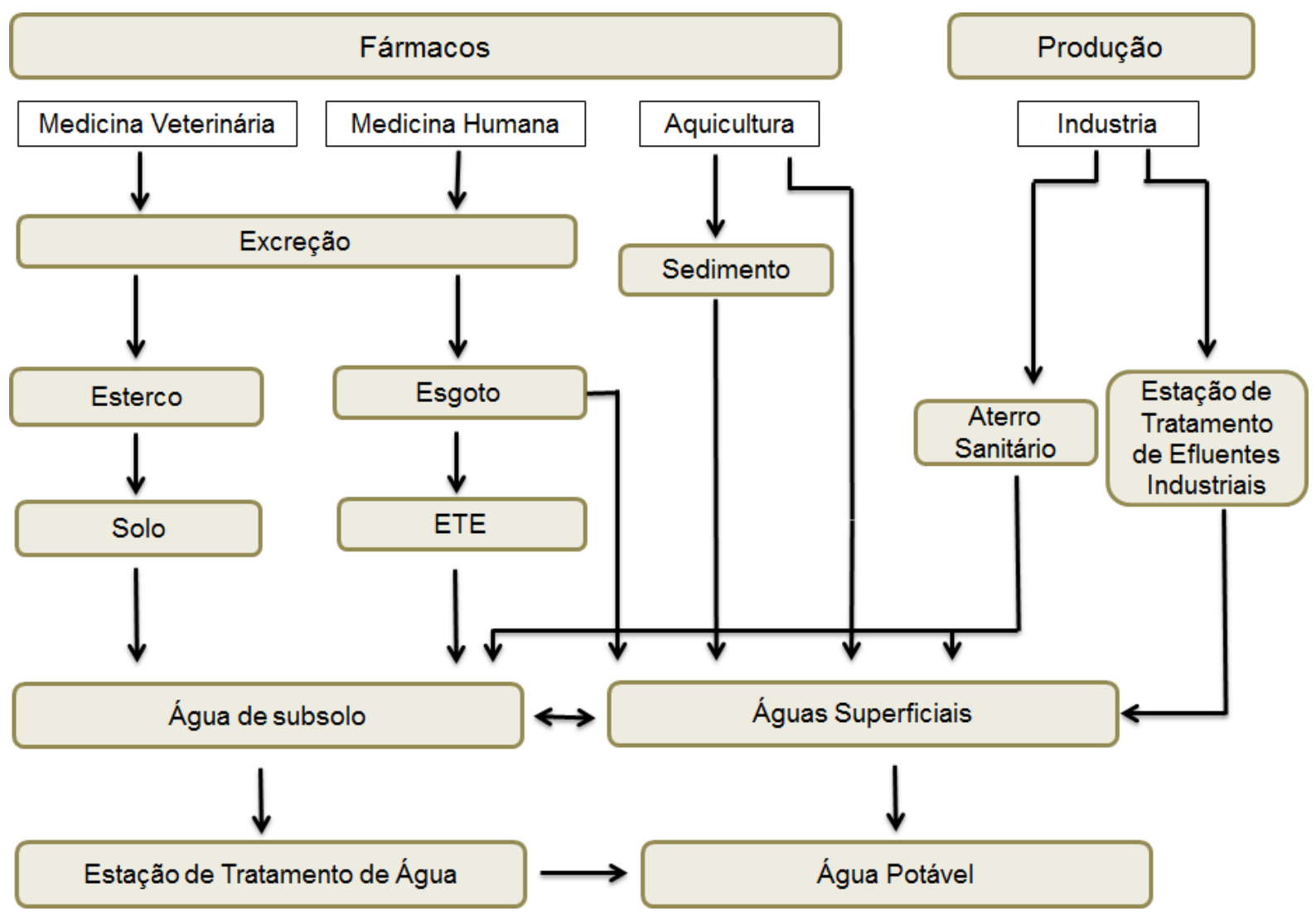

Figura 1 : Rota de fármacos no meio ambiente (adaptado de HALLING-SORENSEN et al., 1998; HIRSCH et al., 1999; HEBERER, 2002).

As estações de tratamento de esgotos (ETE) têm papel fundamental na emissão desses compostos para o ambiente aquático. Nas ETE, os fármacos 
podem ser degradados, adsorvidos no lodo ou ainda reativados, como resultado da atividade microbiana. Estudos de degradação em ETE de analgésicos, antibióticos, oncolíticos, hormônios, entre outros, variaram quanto à biodegradação desses compostos (HALLING-SORENSEN et al., 1998). As concentrações de fármacos encontradas em ambientes aquáticos estão relacionadas com o padrão de consumo dos mesmos pela população, pela taxa de remoção das ETE, pelo tipo de efluente que aporta nas ETEs e pela sazonalidade, como têm indicado alguns estudos (MELLO et al., 2009).

\subsection{Quinolonas}

As quinolonas representam uma das classes mais importantes de agentes antimicrobianos sintéticos altamente eficazes no tratamento de diversas formas de infecção, sendo utilizadas mundialmente nas infecções de origem bacteriana; suas indicações terapêuticas foram inicialmente aplicadas às infecções urinárias além de infecções em quase todo o organismo (OTERO et al., 2001a). Esta classe de agentes antimicrobianos é extensivamente utilizada na medicina humana e veterinária, sendo muito importantes no combate a organismos gram-negativos e gram-positivos. A última geração destes agentes chega a ser ativa contra bactérias anaeróbias, incluindo aquelas resistentes aos $\beta$-lactâmicos e às sulfonamidas (SOUSA, 2007; SILVA, 2004). Em 1962, LESHER desenvolveu o primeiro composto da família das quinolonas, o ácido nalidíxico (Figura 2), composto que apresentou atividade apenas contra enterobactérias (NAVA, 2007). 
<smiles>CCn1cc(C(=O)O)c(=O)c2ccc(C)nc21</smiles>

Figura 2 : Estrutura do ácido nalidíxico (LESHER et al., 1962).

Devido ao ácido nalídixico não atingir a concentração apropriada na maior parte dos tecidos e órgãos, sua indicação se limita ao tratamento de infecções de origem urinária simples (NAVA, 2007). Como consequência, este antibiótico tem sido sintetizado e testado de forma a aumentar o espectro antimicrobiano e a utilidade destes fármacos (SILVA, 2004).

Na década de 1970, as sínteses do ácido oxolínico e da cinoxacina não representaram avanços terapêuticos significativos, apesar das atividades antimicrobianas destes compostos serem um pouco superiores à do ácido nalidíxico (NAVA, 2007). Nesse mesmo período, foi realizada a síntese do ácido pipemídico (Figura 3), com a inclusão do grupo piperazínico, representando um importante avanço das quinolonas.<smiles>CCn1cc(C(=O)O)c(=O)c2cnc(N3CCNCC3)nc21</smiles>

Figura 3 : Estrutura do ácido pipemídico (WANG et al., 2010).

Em 1978, descobriu-se a norfloxacina, ao se incluir o átomo de flúor na estrutura do ácido pipemídico, fato que proporcionou um avanço na síntese de 
inumeros antibióticos do grupo fluoroquinolonas ( $F Q)$, a exemplo da ciprofloxacina (ROCHA et al., 2011).

As fluoroquinolonas $(F Q)$ têm sido amplamente prescritas para os tratamentos humano e veterinário devido a sua ação bactericida rápida contra uma grande variedade de microrganismos comuns, com destaque para a ciprofloxacina, enrofloxacina e norfloxacina (SOUZA, 2007; NAVA, 2009). A sintese da levofloxacina, em 1997, foi primeiro composto identificado na terceira geração das $F Q$, por apresentar elevada atividade pneumocócica, sendo uma alternativa eficiente para tratamento das infecções de membros superiores e inferiores dos tratos respiratórios (LOPES, 2004).

As FQ apresentam atividade gram negativa intrínseca, pois a adição de flúor à molécula aumenta a lipofilicidade dos compostos, ou seja, aumenta sua atividade contra organismos gram negativos (SUKUL E SPITELLER, 2007).

Em geral, as fluoroquinolonas são parcialmente metabolizadas no fígado e excretadas na bile e urina, com alta concentração de drogas ativas (fármaco inalterado ou metabólito ativo). As vias metabólicas desses agentes são comuns à oxidação, sulfonação de acetilação (OTERO et al., 2001b). Devido a sua alta eficiência, esta classe de antibióticos é muito utilizada, sendo sua principal via de eliminação realizada pela urina. Aproximadamente $70 \%$ das fluoroquinolonas excretadas permanecem de forma inalterada e cerca de $30 \%$ na forma de seus metabólitos (JUNIOR, 2007).

Devido ao seu alto consumo, as FQ têm sido frequentemente detectadas no ambiente aquático. As $\mathrm{FQ}$ podem entrar no meio ambiente por várias rotas, incluindo as águas residuais municipais e efluentes industriais, lodo de esgoto, esterco de criação de animais e escoamento agrícola (ZHANG e HUANG, 2005; WANG et al., 2010). Sua ocorrência tem sido identificada em concentrações máximas em de micrograma por litro $\left(0,1 \mu \mathrm{g} \mathrm{L}^{-1}\right)$ e miligramas por kilograma $\left(0,1 \mathrm{mg} \mathrm{kg}^{-1}\right)$. Estas drogas, inicialmente presentes nos corpos aquáticos, rapidamente se depositam no solo e nos sedimentos, devido à forte adsorção em minerais e matéria orgânica (STURINI et al., 2012). Sendo assim, a preocupação com o ambiente advinda do uso das $F Q$ não é apenas com base nos seus potenciais para promover a resistência aos antibióticos, mas também em seus perfis de ecotoxicidade desfavoráveis (GOLET et al., 2002). 


\subsection{Enrofloxacina}

A enrofloxacina [ácido 1,4-diidro-1-ciclopropil-7-(4-etil-1-piperazinil)-6-fluoro4-oxo-3-quinolinacarboxílico, CAS 93106-60-6, Figura 4], que faz parte da segunda geração das fluoroquinolonas, é uma 6-fluoroquinolona sintética que atua inibindo a DNA girase bacteriana, sendo eficaz no tratamento das principais infecções que afetam os animais (aves, gados, suínos). A enrofloxacina foi sintetizada em 1980 pelos pesquisadores GROHE e PETERSON, da Bayer, sendo desenvolvida exclusivamente para o uso em medicina veterinária e introduzida no mercado em 1988 (MITCHELL, 2006). Possui estrutura molecular $\mathrm{C}_{19} \mathrm{H}_{22} \mathrm{FN}_{3} \mathrm{O}_{3}$ e massa molar igual a $359,4 \mathrm{~g} \mathrm{~mol}^{-1}$.

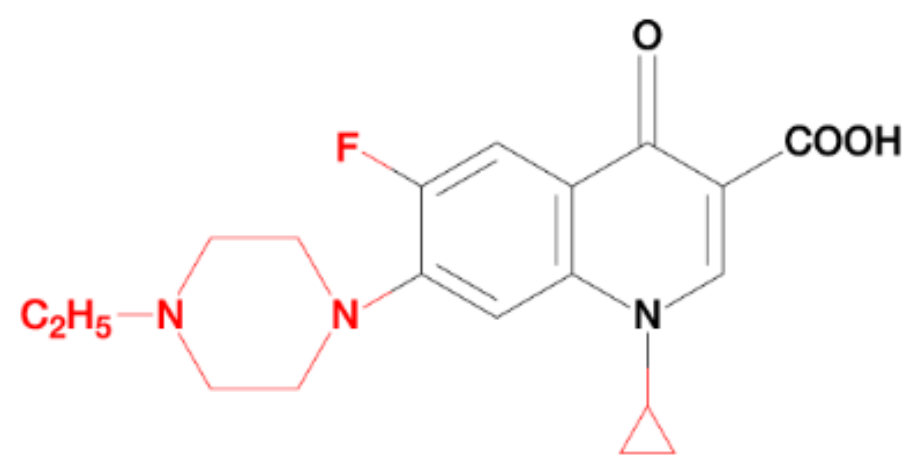

Figura 4 : Fórmula estrutural da enrofloxacina (MITCHELL, 2006).

A enrofloxacina (ENRO) é comumente utilizada em aquicultura, de forma profilática ou desinfetante, para prevenir doenças, ou como um agente quimioterápico para controlar doenças. Este antibiótico é eficaz contra infecções bacterianas comuns, sendo administrado através de ração medicada ou tratamentos de banho. Por não ser totalmente metabolizada após ter sido administrada em animais aquáticos, resíduos de enrofloxacina e também do seu metabólito, a ciprofloxacina, podem ser transferidos para as águas 
superficiais ou para sedimentos (LIN et al., 2010), sendo frequentemente detectados em ambientes aquáticos.

A enrofloxacina e a ciprofloxacina apresentam potencial de toxicidade ecológico e risco para a saúde humana, pois foram, respectivamente, classificadas como compostos de "médio" e "muito alto" risco. Uma vez que a enrofloxacina e ciprofloxacina são excretadas por animais na água ou sedimentos, elas acabam sendo submetidas à transformação ou degradação a diferentes taxas, dependendo da natureza dos fatores, bióticos, abióticos e ambientais (LIN et al., 2010). Estes compostos têm sido encontrados no meio ambiente em concentrações médias típicas de $0,02 \mu \mathrm{g} \mathrm{L}^{-1}$ a $0,12 \mu \mathrm{g} \mathrm{L}^{-1}$ nos EUA (KOLPIN et al., 2002). No Brasil a concentração média dos antibióticos giram em torno de $0,1 \mu \mathrm{g} \mathrm{L}^{-1}$ a $1,0 \mu \mathrm{g} \mathrm{L}^{-1}$ em estações de tratamento de esgoto (ETE) e em rios, as concentrações médias encontram-se entre $0,02 \mu \mathrm{g} \mathrm{L}^{-1} \mathrm{e}$ $0,04 \mu \mathrm{g} \mathrm{L}^{-1}$ (BILA e DEZOTTI, 2003). No entanto no Brasil existem poucos estudos de quantificação da ENRO nas ETE e nas águas superficiais.

\subsection{Processos Oxidativos Avançados (POA)}

Ao longo das últimas décadas, os processos oxidativos avançados têm sido alternativas tecnológicas extremamente eficientes para destruir substâncias orgânicas de difícil degradação e muitas vezes encontradas em baixas concentrações, pois, é um processo bastante efetivo na oxidação química de poluentes (NOGUEIRA e JARDIM, 1998; MELO et al., 2009). A maioria dos POA apresenta sistemas reacionais diferentes. No entanto, em todos os processos, a oxidação ocorre por meio da produção de radicais hidroxila $\left({ }^{\bullet} \mathrm{OH}\right)$, espécies altamente oxidantes e muito pouco seletivas (ANDREOZZI et al., 1999).

Um dos principais mecanismos de reação dos radicais hidroxila é a abstração de hidrogênio (Equação 1), formando radicais orgânicos que reagem com o oxigênio molecular gerando radicais peroxila (Equação 2), que iniciam 
reações de degradação produzindo compostos intermediários, podendo chegar até mesmo a $\mathrm{CO}_{2}$ e água (LEGRINI et al., 1993)

$$
\begin{aligned}
& \mathrm{HO}^{\bullet}+\mathrm{RH} \rightarrow \mathrm{R}^{\bullet}+\mathrm{H}_{2} \mathrm{O} \\
& \mathrm{R}^{\bullet}+\mathrm{O} 2 \rightarrow \mathrm{RO}_{2}^{\circ}
\end{aligned}
$$

Os POA são classificados em sistemas homogêneos e heterogêneos, em que o radical hidroxila é gerado com ou sem irradiação ultravioleta. Entre eles, podem-se citar os processos que envolvem a utilização de ozônio $\left(\mathrm{O}_{3}\right)$, radiação ultravioleta (UV), peróxido de hidrogênio $\left(\mathrm{H}_{2} \mathrm{O}_{2}\right)$, reagentes de Fenton ou foto-Fenton, que utilizam $\mathrm{Fe}(\mathrm{II})$ ou $\mathrm{Fe}(\mathrm{III})$ e $\mathrm{H}_{2} \mathrm{O}_{2}$, e fotocatálise heterogênea, que utiliza semi-condutores como dióxido de titânio $\left(\mathrm{TiO}_{2}\right)$ combinado à radiação UV (NOGUEIRA e JARDIM, 1998). A Tabela 1 apresenta uma proposta de classificação dos processos oxidativos avançados (HUANG et al., 1993).

\begin{tabular}{|c|c|}
\hline Com ou sem Radiação & Tipo de sistemas \\
\hline COM RADIAÇÃO & $\begin{array}{c}\text { Sistemas Homogêneos } \\
\mathrm{H}_{2} \mathrm{O}_{2} / \mathrm{UV} \\
\text { Feixe de elétrons } \\
\text { Ultrassom (US) } \\
\mathrm{H}_{2} \mathrm{O}_{2} / \mathrm{US} \\
\mathrm{UV} / \mathrm{US} \\
\mathrm{O}_{3} / \mathrm{UV} \\
\text { Sistemas Heterogêneos } \\
\mathrm{TiO}_{2} / \mathrm{UV} \\
\mathrm{TiO}_{2} / \mathrm{H}_{2} \mathrm{O}_{2} / \mathrm{UV}\end{array}$ \\
\hline SEM RADIAÇÃO & $\begin{array}{c}\text { Sistemas Homogêneos } \\
\mathrm{H}_{2} \mathrm{O}_{2} / \mathrm{Fe}^{2+} \\
\mathrm{O}_{3} / \mathrm{H}_{2} \mathrm{O}_{2} \\
\mathrm{O}_{3} / \mathrm{HO}^{\bullet} \\
\text { Sistemas Heterogêneos } \\
\text { Eletro-Fenton }\end{array}$ \\
\hline
\end{tabular}

Tabela 1 : Classificação dos processos oxidativos avançados (HUANG et al., 1993).

Outro exemplo de POA é a cavitação, gerada por radiação ultra-sônica ou por constrições (GOGATE e PANDIT; 2004a), as reações de Fenton (Fenton, 
1894) e foto-Fenton (LEI et al., 1998; PÉREZ et al., 2002; TEIXEIRA et al., 2004); irradiação direta do contaminante ou fotólise, irradiação com feixes de elétrons, raios $X$ ou raios gama; descargas elétricas não térmicas e oxidação com hipoclorito (SZPYRKOWICZ et al., 2001).

Nos sistemas homogêneos, a degradação pode ser feita de duas maneiras (TEIXEIRA e JARDIM, 2004):

- fotólise direta com radiação UV, onde a radiação é a responsável principal pela degradação do poluente;

- geração de radicais hidroxila.

Os sistemas heterogêneos são identificados pela presença de catalisadores. Um exemplo é a fotocatálise baseado em $\mathrm{TiO}_{2}$ (TEIXEIRA e JARDIM, 2004).

A eficiência dos POA é fortemente influenciada pela qualidade do efluente a ser tratado. Por exemplo, concentrações altas de espécies sequestradoras de radicais hidroxilas, como o carbonato, bicarbonato e $\mathrm{o}$ íon cloreto também reduzem a eficiência do tratamento (CRISTINO, 2006). A Tabela 2 apresenta o potencial padrão de redução de importantes agentes oxidantes. O radical hidroxila é capaz de oxidar quase todos os compostos orgânicos a $\mathrm{CO}_{2}$ e água, com constantes de velocidades da ordem de $10^{6}-10^{9} \mathrm{~L} \mathrm{~mol}^{-1} \mathrm{~s}^{-1}$, exceto alguns compostos orgânicos mais simples como ácido acético, ácido oxálico e derivados clorados como clorofórmio (ANDREOZZI et al., 1999; PERA-TITUS et al., 2004).

Tabela 2 : Potencial padrão de redução $(E P H)$ para vários oxidantes (Fonte: US PEROXIDE, 2008).

\begin{tabular}{lc}
\hline$\quad$ Agente Oxidante & $\mathrm{E}^{\circ}(\mathrm{V}$ EPH $)$ \\
\hline Flúor & 3,0 \\
Radical hidroxil $\left(\mathrm{HO}^{\bullet}\right)$ & 2,8 \\
Ozônio & 2,1 \\
Peróxido de hidrogênio & 1,8 \\
Permanganato de potássio & 1,7 \\
Dióxido de cloro & 1,5 \\
Cloro & 1,4 \\
\hline
\end{tabular}


A radiação UV é usada para a desinfecção de água e vem sendo muito estudada para a degradação de compostos orgânicos presentes em efluentes. O processo é baseado no fornecimento de energia na forma de radiação UV, a qual é absorvida por moléculas de compostos recalcitrantes, que passam para estados excitados e têm tempo suficiente para eventualmente sofrerem reações fotoquímicas (ESPLUGAS et al., 2002).

O aspecto econômico do POA pode ser uma desvantagem, devido ao consumo de energia elétrica pelas lâmpadas UV. Contudo, a combinação de um POA como tratamento preliminar, ou como tratamento de polimento pode constituir uma opção interessante.

\subsubsection{Fotólise com radiação ultravioleta (UV)}

A fotólise com ultravioleta utiliza a radiação como a única fonte capaz de destruir o poluente e, se comparada com processos envolvendo geração de radical hidroxila, apresenta, geralmente, baixa eficiência. Para ser fotolisado, o contaminante deve absorver a radiação incidente, resultando na sua degradação a partir do seu estado excitado (VASCONCELOS e GOMES, 2009). A taxa com que ocorre a fotocatálise depende do rendimento quântico, que corresponde à razão entre a taxa da reação fotoquímica e a taxa de absorção de fótons pelo reagente.

A degradação de compostos farmacêuticos por radiação UV tem sido descrita na literatura. NAKAJIMA et al. (2005) estudaram a fotocatálise do cetoprofeno, observando a geração de radicais livres e espécies reativas de oxigênio por foto-irradiação e identificando três produtos diferentes de degradação, a partir do que propuseram mecanismos de foto decomposição do composto, sendo a foto-transformação do cetoprofeno o seu principal processo de eliminação no meio ambiente.

A radiação UV também é muito utilizada para complementar a degradação de compostos orgânicos em POA. Alguns autores citam a fotólise direta de compostos orgânicos usando somente radiação UV. Em geral, somente 
radiação UV não é suficiente para alcançar a mineralização total de compostos orgânicos (BÉLTRAN et al., 1997; GOI e TRAPIDO, 2002).

YANG LI et al. (2011) estudaram a fotólise da enrofloxacina em água sob luz solar simulada usando uma lâmpada de xenônio (CHF-XM-500 W, 300-800 $\mathrm{nm})$. Os resultados mostraram que a fotólise da enrofloxacina ocorreu com cinética aparente de primeira ordem. Em comparação com condições ácidas e básicas, a taxa de fotólise apresentou-se mais rápida em meio neutro. O nitrato pode diminuir acentuadamente a fotólise direta da enrofloxacina, porque pode absorver fótons, competindo com a ENRO. Os resultados indicaram que o antibiótico foi submetido à fotooxidação via radical hidroxila e oxigênio singlete $\left({ }^{1} \mathrm{O}_{2}\right)$. Após a irradiação por 90 minutos, houve a remoção de apenas $13 \%$ do carbono orgânico total (COT), indicando que não houve mineralização completa do fármaco, apesar da degradação de $58,9 \%$ da enrofloxacina. A fotólise da enrofloxacina envolveu três vias principais: descarboxilação, desfluoração e piperazinil N4-desalquilação. A taxa de inibição de bioluminescência usando Vibrio fischeri indicada à geração de alguns intermediários mais tóxicos do que a enrofloxacina.

STURINI et al. (2010) estudaram a degradação de enrofloxacina e marbofloxacina, amplamente utilizadas na medicina veterinária e conhecidas por estarem presentes em águas superficiais em concentrações de $\mu \mathrm{g} \mathrm{L}^{-1}$. A degradação destes poluentes, à concentração inicial de 5,0-50,0 $\mathrm{g} \mathrm{L} \mathrm{L}^{-1}$, foi completada após uma hora de exposição à luz solar, no verão, obedecendo a uma cinética de primeira ordem. Os produtos de fotodegradação da enrofloxacina surgiram de três vias: degradação oxidativa da cadeia lateral de piperazina, desfluoração redutora e solvólise do flúor. Quanto ocorre a clivagem homolítica do composto marbofloxacina, há a formação de duas quinolonas. As taxas das reações de fotodegradação foram pouco afetadas pela presença de $\mathrm{Ca}^{+2}\left(200 \mathrm{mg} \mathrm{L}^{-1}\right), \mathrm{Mg}^{+2}\left(30 \mathrm{mg} \mathrm{L}^{-1}\right), \mathrm{Cl}^{-}\left(30 \mathrm{mg} \mathrm{L}^{-1}\right)$ e ácido húmico ( $\left.1 \mathrm{mg} \mathrm{L}^{-1}\right)$, mas aumentou na presença de fosfato $\left(20 \mathrm{mg} \mathrm{L}^{-1}\right)$. A degradação mais rápida de enrofloxacina ocorreu em $\mathrm{pH}=8$, na qual a forma iônica estava presente, enquanto que para marbofloxacina, a forma catiônica era a mais reativa. 


\subsubsection{Processo $\mathrm{H}_{2} \mathrm{O}_{2} / \mathrm{UV}$}

Um dos processos oxidativos avançados mais antigos e eficientes na remoção de contaminantes presentes nas águas e efluentes é o processo que combina peróxido de hidrogênio com radiação ultravioleta $\left(\mathrm{H}_{2} \mathrm{O}_{2} / \mathrm{UV}\right)$; nessas condições, ocorre a quebra homolítica da molécula do $\mathrm{H}_{2} \mathrm{O}_{2}$, produzindo radical hidroxila (MELLO et al., 2009) (Equação 3). Este processo tem como vantagens a não formação de lodo, importante redução da carga orgânica e a facilidade operacional. $\mathrm{O}$ emprego desse processo tem se mostrado efetivo no processo de desinfecção de efluentes secundários, na remoção de cor e de contaminantes orgânicos dissolvidos (MELLO et al., 2009).

$\mathrm{H}_{2} \mathrm{O}_{2}+h v \rightarrow 2 \mathrm{HO}^{\circ}$

$\mathrm{O}$ processo $\mathrm{H}_{2} \mathrm{O}_{2} / \mathrm{UV}$ é realizado quase sempre utilizando lâmpadas de vapor de mercúrio de baixa ou média pressão e depende do $\mathrm{pH}$ e da temperatura, uma vez que em meio alcalino a dissociação do $\mathrm{H}_{2} \mathrm{O}_{2}$ é favorecida formando o íon $\mathrm{HO}_{2}{ }^{-}$. O processo é também prejudicado devido ao sequestro de radicais hidroxila por íons carbonato e bicarbonato (Equações 4 e 5). A ação competitiva desses íons constitui a principal interferência nos processos oxidativos baseados na produção de radicais hidroxila (MELLO et al., 2009).

$\mathrm{HO}^{\circ}+\mathrm{HCO}_{3}^{-} \rightarrow \mathrm{H}_{2} \mathrm{O}+\mathrm{CO}_{3}{ }^{-}$

$\mathrm{HO}^{\circ}+\mathrm{CO}_{2}^{-} \rightarrow \mathrm{HO}^{-}+\mathrm{CO}_{3}^{-}$

Geralmente se empregam lâmpadas que emitem em 254 nm, mas como a absorção do $\mathrm{H}_{2} \mathrm{O}_{2}$ é máxima a $220 \mathrm{~nm}$, seria mais conveniente o uso de lâmpadas de $\mathrm{Xe} / \mathrm{Hg}$, mais caras, mas que emitem na faixa 210-240 nm (DOMÈNECH et al., 2001). Em excesso de peróxido de hidrogênio e com altas 
concentrações de ${ }^{\bullet} \mathrm{OH}$, podem ocorrer reações que atuam inibindo a degradação.

FINK et al. (2012) investigaram a oxidação química da enrofloxacina pelo peróxido de hidrogênio catalisado por nanopartículas de óxido de cobre (CuO), carboneto de titânio (TiC) e nitreto de silício $\left(\mathrm{Si}_{3} \mathrm{~N}_{4}\right)$. O meio de reação era constituído por uma solução aquosa de $1000 \mathrm{\mu g} \mathrm{L}^{-1}$ de enrofloxacina, $0,1 \mathrm{~g} \mathrm{~L}^{-1}$ de nanopartículas (CuO, $<50 \mathrm{~nm}$, Sigma) e $0,8 \mathrm{~mol} \mathrm{~L}^{-1}$ de peróxido de hidrogênio. $O$ processo catalisado por nanopartículas foi mais eficiente para 0 $\mathrm{CuO}$.

CUNHA et al. (2009) estudaram estratégias de degradação de medicamentos que não são "destruídos" por tratamentos convencionais, mas que em condições adequadas podem sofrer mineralização total através dos Processos Oxidativos Avançados. Os experimentos foram realizados em um reator fotoquímico utilizando uma lâmpada de vapor de mercúrio de média pressão $(125 \mathrm{~W})$. A solução de fármaco a ser tratada continha $4,4 \times 10^{-4} \mathrm{~mol} \mathrm{~L}^{-1}$ de enrofloxacina, $7,6 \times 10^{-4} \mathrm{~mol} \mathrm{~L}^{-1}$ de $\mathrm{Fe}^{2+}$ e $60 \mathrm{~mL}$ de uma solução de $\mathrm{H}_{2} \mathrm{O}_{2} 1,7$ mol L $\mathrm{L}^{-1}$ adicionada com o uso de uma bomba. $\mathrm{O} \mathrm{pH}$ foi controlado e mantido em torno de 3,0. Amostras de $10 \mathrm{~mL}$ foram coletadas em intervalos de tempo apropriados e analisadas em um equipamento para medida de COT para obter resultados em termos de carbono orgânico total dissolvido. Os resultados iniciais apresentaram remoção de carbono orgânico total de $90 \%$ nas condições experimentais utilizadas, mostrando que o método utilizado é útil para o tratamento de água contaminada pelo fármaco em estudo.

\subsection{Substâncias Bio-orgânicas (BOS)}

No quadro global de gestão de resíduos e desenvolvimento sustentável, os resíduos sólidos urbanos têm sido propostos como possível fonte de compostos com diversos tipos de aplicações (MONTONERI et al., 2009, SAVARINO et al., 2009), como os chamados compostos bio-orgânicos (BOS). Desde 2007, pesquisadores italianos da Universidade de Torino vêm 
desenvolvendo projetos financiados pela região italiana do Piemonte, dedicados à caracterização e avaliação de possibilidades de emprego de novos produtos de base biológica, obtidos através separação dos compostos orgânicos presentes nos resíduos sólidos urbanos (MONTONERI et al., 2009).

\subsubsection{Produção de BOS}

A primeira extração das substâncias húmicas (HS) do solo ocorreu no ano de 1876, na qual os microrganismos presentes do solo foram eliminados pelo processo de aquecimento e filtração da solução contendo solo e solução de $\mathrm{NaOH} 1 \mathrm{~mol} \mathrm{~L}^{-1}$. Após eliminação dos microrganismos foi adicionada ao solo solução de ácido clorídrico $(\mathrm{HCl})$ até $\mathrm{pH}$ próximo de 1 . A suspensão obtida passou por processo de centrifugação e purificação do soluto, formando assim os ácidos húmicos (KAMIYA, 1998).

Tratamentos semelhantes também foram adotados para a biomassa obtida a partir da fração orgânica dos resíduos sólidos urbanos (RSU), que são substâncias consideradas semelhantes às substâncias húmicas, chamadas substâncias bio-orgânicas (BOS) (SCHULTEN e SCHNITEZ, 1993).

O tratamento de RSU é realizado utilizando digestores onde os compostos bio-orgânicos presentes na lama que deixa o digestor encontram-se em concentrações elevadas, o que permite a extração de quantidades significativas de BOS em comparação com a extração de substâncias húmicas de ambientes naturais.

O processo de isolamento de BOS ocorre a partir da adição de uma solução aquosa contendo $0,1 \mathrm{~mol} \mathrm{~L}^{-1}$ de $\mathrm{NaOH}$ e de uma solução aquosa $0,1 \mathrm{~mol} \mathrm{~L}^{-1}$ de pirofosfato de sódio $\left(\mathrm{Na}_{4} \mathrm{P}_{2} \mathrm{O}_{7}\right)$ na proporção de 1:50 v/v durante 24 horas a $65^{\circ} \mathrm{C}$, sob atmosfera de nitrogênio. A suspensão obtida é arrefecida a temperatura ambiente e centrifugada a $6000 \mathrm{rpm}$ por 20 minutos, ocorrendo o primeiro processo de extração da fase sólida. Em seguida à fase líquida é adicionada solução de $\mathrm{H}_{2} \mathrm{SO}_{4} 50 \%$ até atingir $\mathrm{pH}=1,5$ para que ocorra a precipitação completa de BOS; nesta fase o composto é separado por 
centrifugação e lavado até atingir pH neutro. Por fim o sólido é secado a vácuo a 60ํㅡ (QUAGLIOTTO et al., 2006).

\subsubsection{Natureza dos BOS}

Os compostos bio-orgânicos são novos materiais de origem biológica, com composições químicas complexas; a massa molar destas substâncias é atualmente assunto de grande controvérsia (BAALOUSHA et al., 2006). A estrutura e as propriedades dos BOS variam de acordo com a fonte a partir da qual são extraídos dos resíduos sólidos urbanos e do tempo de compostagem.

A presença de cadeias alquil e aromáticos ligados a uma vasta variedade de grupos funcionais oxigenados tais como álcoois, fenóis, fenil-éter, amidas e grupos carboxílicos é confirmada por espectrometria de ressonância magnética nuclear (RMN) e espectroscopia de infravermelho (IR) $\mathrm{H}^{1}$ e $\mathrm{C}^{13}$ (MONTONERI et al., 2008).

O processo de compostagem forma em geral um produto com um baixo teor de proteínas e polissacarídeos e grande quantidade de substâncias com estruturas químicas similares as da matéria orgânica natural (ácidos húmicos). MONTONERI et al. (2008) estudaram duas substâncias húmicas: a primeira extraída de matéria orgânica de resíduos sólidos urbanos com 15 dias de compostagem $\left(\mathrm{HS}_{1}\right)$ e a segunda produzida a partir de matéria orgânica proveniente de lixo urbano vegetal antes do processo de compostagem $\left(\mathrm{HS}_{2}\right)$. Observaram-se diferenças significativas: no segundo caso, o material obtido apresentou uma quantidade menor de grupos carboxílicos, fenóis e fenil-éter em favor de maior concentração de cadeias alifáticas e de grupos álcoois.

Estudos focaram a determinação da massa molar dos BOS sem obter conclusões definitivas; no entanto, QUAGLIOTTO (2006) observou a presença de uma distribuição relativamente ampla de massas molares, a partir de centenas de milhares de Daltons. A Figura 5 apresenta algumas hipóteses de estruturas de fragmentos de BOS, com base na informação obtida a partir de vários testes de caracterização (QUAGLIOTTO et al., 2008). 


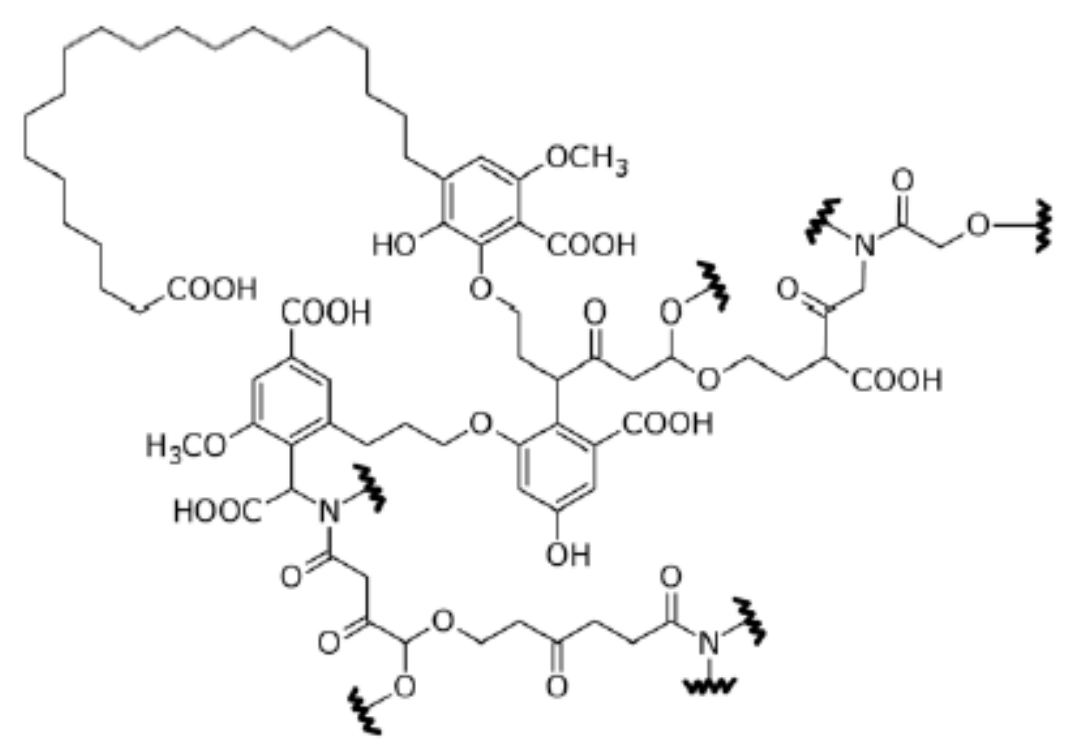

Figura 5- Fragmento hipotético de uma molécula presente na fração solúvel orgânica extraída a partir do composto (QUALGLIOTTO et al., 2008)

A complexidade dos BOS, a variedade de grupos funcionais e a distribuição da massa molar torna difícil a caracterização destas substâncias. Além disso, observam-se diferenças na estrutura e propriedades, dependendo da fonte de BOS, das condições e do tempo de compostagem (MONTONERI et al., 2008).

\subsubsection{Propriedades dos BOS como surfactantes}

Os surfactantes são moléculas caracterizadas pela presença de um grupo hidrofóbico, geralmente um hidrocarboneto de cadeia longa, e um grupo hidrofílico, podendo ser classificados como tensoativos aniônicos, catiônicos e não iônicos (MONTONERI et al., 2008).

Quando um agente tensoativo é adicionado à água, suas moléculas orientam sua parte hidrofóbica para o ar e os grupos hidrofílicos para a água. Isso resulta em decréscimo progressivo da tensão superficial. Ao atingir uma concentração em solução igual à concentração micelar crítica (CMC), formamse agregados denominados micelas e a tensão superficial mantém-se praticamente inalterada (SCHULTEN e SCHNITZER, 1993). Portanto, os BOS 
são capazes de reduzir a tensão superficial de uma solução aquosa e de dar origem à formação de micelas. No entanto, a CMC varia com o tipo de BOS considerado, o que depende das diferenças estruturais entre os diferentes produtos. Estas diferenças devem-se principalmente ao tipo de lixo orgânico (vegetal, alimento, verde urbano) e às condições do processo de biodegradação (aeróbia/anaeróbia, tempo, temperatura) a que estes resíduos foram submetido (SCHULTEN e SCHNITZER, 1993).

\subsubsection{Mecanismo de fotodegradação}

Em águas naturais, uma via fotoquímica de degradação de poluentes orgânicos é a fotólise indireta que inclui, entre outras, reações com compostos presentes na matéria orgânica natural (MON), excitados ao estado triplete. A fração MON (ácidos húmicos e fúlvicos) absorve radiação com comprimento de onda superior a $300 \mathrm{~nm}$, dando origem a espécies reativas (GE et al., 2009). Os BOS apresentam estrutura similar à da MON presente na água. Esta propriedade tem sido estudada principalmente para a compreensão dos mecanismos de autopurificação da água.

As substâncias húmicas (HS) presentes na MON podem absorver a luz solar e gerar estados excitados triplete e elétrons solvatados, de acordo com as Equações 6 e 7 :

$$
\begin{aligned}
& H S+h v \rightarrow{ }^{3} H S^{*} \\
& H S+h v \rightarrow H S^{+}+e_{a q}^{-}
\end{aligned}
$$

$\mathrm{Na}$ presença de oxigênio dissolvido, há formação de várias espécies reativas oxigenadas, tais como radicais hidroxila $\left({ }^{\bullet} \mathrm{OH}\right)$ e oxigênio singlete $\left({ }^{1} \mathrm{O}_{2}\right)$, gerando peróxido de hidrogênio (KHODJA et al., 2006).

A atividade dessas espécies em solução pode ser explicada considerando duas possíveis hipóteses como mecanismos de reação: a primeira é a 
transferência de átomos de hidrogênio; a segunda, a transferência de energia. O mecanismo de transferência de átomos de hidrogênio tem sido admitido para as reações que ocorrem na presença de ácidos húmicos. Acredita-se que o estado excitado triplete dos compostos húmicos está envolvido na extração de átomos de hidrogênio do substrato orgânico, formando radicais orgânicos (KHODJA et al., 2006):

$$
\begin{aligned}
& { }^{3} \mathrm{HS}^{*}+\mathrm{H}-\text { substrato } \rightarrow \mathrm{HSH}^{\bullet}+\text { substrato } \\
& \mathrm{HSH}^{\bullet}+\mathrm{O}_{2} \rightarrow \mathrm{HS}+\mathrm{HOO}^{\bullet} \\
& e_{a q}^{-}+\mathrm{O}_{2} \rightarrow \mathrm{O}_{2}^{\bullet-} \\
& \mathrm{O}_{2}^{\bullet-}+\mathrm{HOO}^{\bullet} \rightarrow \mathrm{H}_{2} \mathrm{O}_{2} \\
& e_{a q}^{-}+\mathrm{H}_{2} \mathrm{O}_{2} \rightarrow \mathrm{OH}^{\bullet}+\mathrm{OH}^{-}
\end{aligned}
$$

A partir das reações dadas pelas Equações 8 a 12, observa-se que o átomo de hidrogênio é transferido para moléculas de oxigênio, eventualmente presentes no sistema. A formação de espécies reativas oxigenadas desencadeia mecanismos radicalares que promovem a degradação do substrato, demonstrando que a fotodegradação mediada pela matéria orgânica dissolvida (ácidos húmicos) é favorecida pela presença de oxigênio dissolvido na solução. Há inibição deste processo caso a atmosfera seja inerte (KHODJA et al, 2006)

MONTONERI et al. (2008) desenvolveram estudos sobre possíveis aplicações de BOS nos processos oxidativos avançados. Na literatura existem trabalhos destinados à classificação do mecanismo de reação e possíveis relações estruturais, além de propriedades fotossensibilizantes dos compostos bio-orgânicos, sendo estes dados aplicados na avaliação do desempenho frente a diferentes substratos. Por exemplo, a fim de desenvolver processos industriais compatíveis com o meio ambiente, foi estudada a possibilidade de utilizar os BOS como auxiliares no processo de tingimento, bem como na 
promoção da fotodegradação do corante presente no efluente industrial (MONTONERI et al., 2008).

MONTONERI et al. (2008) estudaram a degradação de compostos aromáticos pertencentes à classe dos corantes nitrogenados (grupo funcional $\left.\mathrm{R}-\mathrm{N}=N R^{\prime}\right)$ na presença de compostos bio-orgânicos. Este estudo foi realizado utilizando alíquotas de uma solução aquosa contendo o corante e o BOS (tipo $\mathrm{HA}_{2}$ ) e irradiando a solução no período de 3 horas, utilizando, lâmpada de xenônio (1500 W), para a qual se filtrou a radiação com comprimentos de onda menores que $340 \mathrm{~nm}$. Ao final da reação observou-se que ao aumentar a concentração do $\mathrm{HA}_{2}$ ocorreu o aumento da fotodegradação do corante em aproximadamente $75 \%$ de remoção e razão corante: $\mathrm{HA}_{2}$ igual a $150 \mathrm{~m} / \mathrm{m}$.

Estudos extensivos sobre a geração de espécies reativas de oxigênio, como resultado da irradiação de BOS, foram realizados por pesquisadores do departamento de Química da Univesidade de Torino (Itália), que lembram que as espécies ${ }^{\circ} \mathrm{OH}$ e ${ }^{1} \mathrm{O}_{2}$ são de importância primária para a degradação de contaminantes orgânicos presentes na solução aquosa irradiada.

\subsubsection{Caracterização dos BOS}

Pouco se conhece na literatura sobre as propriedades dos compostos bioorgânicos (BOS), mas alguns grupos funcionais já foram identificados e estão apresentados na Tabela 3.

Tabela 3 : Tipos e distribuição de grupos funcionais presentes nos BOS (PREVOT et al., 2008).

\begin{tabular}{|c|c|c|c|c|c|c|c|}
\hline $\begin{array}{c}\text { Grupo } \\
\text { Funcional }\end{array}$ & Cal & $\mathrm{CN}$ & $C=C$ & $\mathrm{PhOH}$ & Phox & $\mathrm{COOH}$ & $C=0$ \\
\hline $\begin{array}{c}\text { Concentração } \\
\left(\text { meq g }^{-1}\right)^{(a)}\end{array}$ & 17,1 & 2,9 & 6,8 & 1,3 & 2,5 & 3,8 & 1,6 \\
\hline
\end{tabular}


Uma aplicação muito promissora dos BOS é seu emprego como auxiliares no tratamento de efluentes contendo fármacos (MONTONERI et al., 2009). A capacidade de aceleração da fotodegradação desses compostos tem sido relatada (MONTONERI et al., 2007).

PREVOT et al. (2012) identificaram alguns compostos bio-orgânicos quanto a sua composição e forma de obtenção (Tabela 4).

Tabela 4 : Características dos biosurfactantes (BOS) empregados neste trabalho. Adaptado de PREVOT et al. (2012) e de ENVIRONBOS (2013).

\begin{tabular}{|c|c|c|c|c|c|c|}
\hline BOS & $\begin{array}{l}\text { Fração Orgânica do lixo } \\
\text { Urbano processado }\end{array}$ & $\begin{array}{l}\text { Sólidos } \\
\text { Voláteis \% } \\
(\mathrm{m} / \mathrm{m})\end{array}$ & $\begin{array}{c}\text { Cinzas } \\
(\%)\end{array}$ & $\begin{array}{c}C \\
(\%)\end{array}$ & $\begin{array}{l}N \\
(\%)\end{array}$ & $\mathrm{C} / \mathrm{N}$ \\
\hline $\begin{array}{l}\text { FORSUD } \\
\text { (BOS A) }\end{array}$ & $\begin{array}{c}\text { Fração orgânica dos } \\
\text { resíduos sólidos urbanos, } \\
\text { após a digestão anaeróbia, } \\
\text { durante } 15 \text { dias. Extração } \\
\text { com NaOH. }\end{array}$ & 84,6 & 20,2 & 45,1 & 7,87 & 5,73 \\
\hline $\begin{array}{l}\text { CVDFT110 } \\
\text { (BOS B) }\end{array}$ & $\begin{array}{c}\text { Resíduos verdes e lodo de } \\
\text { compostagem do } \\
\text { FORSUD por } 110 \text { dias. } \\
\text { Extração com } \mathrm{NaOH} .\end{array}$ & 72,7 & 30,2 & 35,5 & 4,34 & 8,17 \\
\hline $\begin{array}{l}\text { CVT230 } \\
\text { (BOS C) }\end{array}$ & $\begin{array}{l}\text { Pilhas de resíduos verdes } \\
\text { aeradas por } 230 \text { dias. } \\
\text { Extração com } \mathrm{NaOH}\end{array}$ & 72,1 & 31,0 & 38,3 & 4,01 & 9,54 \\
\hline
\end{tabular}

Carbono (C); Nitrogênio (N)

Estes produtos foram caracterizados pelo grupo de pesquisa do Departamento de Química da Universidade de Torino, tendo sido o CVT 230 (BOS C) caracterizado por ALLERA (2012) quanto ao teor de água e de cinzas.

A composição elementar do BOS C é determinada relativamente através da concentração de carbono e nitrogênio identificados na Tabela 4. A relação $\mathrm{C} / \mathrm{N}$, que depende do processo de compostagem, é um parâmetro de grande importância para identificar o potencial como fertilizante dos BOS. Este parâmetro reflete a extensão da decomposição (aeróbia e/ou anaeóbia) da matéria orgânica medida através de microorganismos que utilizam carbono como fonte de energia e o nitrogênio para a formação de estruturas celulares. 
Portanto, pode-se afirmar que a relação $\mathrm{C} / \mathrm{N}$ não depende apenas do tipo de biomassa, mas também da duração e tipo de tratamento microbiológico utilizado (SENESI, 2001).

ALLERA (2012) caracterizou o CVT230 (BOS C) no estado sólido por meio de espectroscopia de $\mathrm{RMN}$ de $\mathrm{C}^{13}$, técnica muito utilizada para substâncias húmicas (MALCOM,1989).

\subsubsection{Vantagens e perspectivas do uso dos BOS}

As propriedades das substâncias bio-orgânicas extraídas apontam para aplicações comerciais e tecnológicas interessantes. A este respeito, ainda há muito a pesquisar e a aperfeiçoar quanto ao processo de extração dos BOS a partir da matéria orgânica. ALLERA (2012) discute a necessidade de reduzir a quantidade de resíduos orgânicos encaminhados para os aterros sanitários, reforçando que a produção de BOS age como tratamento e forma de eliminar resíduos orgânicos bem como seu potencial de utilização como fonte de substâncias como propriedades tensoativas.

A capacidade de fotodegradação das substâncias húmicas é de grande importância, uma vez que a utilização dessas substâncias nos POA pode substituir outros reagentes, o que confirma a vantagem de utilizar os compostos bio-orgânicos como catalisadores ou coadjuvantes nos processos oxidativos avançados (GARBIN et al., 2007)

Os compostos bio-orgânicos possuem em sua composição elementos metálicos provenientes de resíduos inorgânicos. Por exemplo, Senesi (2001) apresenta resultados obtidos por espectroscopia de ICP (Inductively Coupled Plasma) (Tabela 6). 
Tabela 5 : Análise dos metais contidos no BOS C por ICP. Valores expressos em \% mássica (SENESI, 2001).

\begin{tabular}{ccccccc}
\hline $\mathbf{S i}$ & $\mathbf{F e}$ & $\mathbf{A l}$ & $\mathbf{M g}$ & $\mathbf{C a}$ & $\mathbf{K}$ & $\mathbf{N a}$ \\
\hline 2,55 & 0,77 & 0,49 & 1,13 & 6,07 & 3,59 & 0,16 \\
\hline
\end{tabular}

A presença de metais de transição em concentrações como as reportadas por SENESI (2001) podem afetar as propriedades dos BOS como fotossensibilizadores. Por exemplo, a presença de ferro na solução permite para ativar os processos Fenton ou foto-Fenton, gerando radicais hidroxila (OU et al., 2007). Outra possibilidade interessante é o emprego de BOS na estabilização de espécies de ferro (III) em solução aquosa, o que pode permitir, por exemplo, o processo foto-Fenton $\left(\mathrm{H}_{2} \mathrm{O}_{2} / \mathrm{Fe}(\mathrm{III}) / \mathrm{UV}\right)$ em meio neutro e levemente básico.

A obtenção, caracterização e avaliação de compostos bio-orgânicos (BOS) têm sido alvo do projeto FP7-PEOPLE-2010-IRSES-Comissão Europeia, desenvolvido no âmbito do programa "Marie Curie Actions"-International Research Staff Exchange Scheme e intitulado "Isolation, Characterization and Screening of Environmental Applications of Bio-Organic Substances Obtained from Urban Biomasses (EnvironBOS)". O projeto EnvironBOS tem os seguintes objetivos: (i) Isolamento e caracterização de BOS a partir de resíduos urbanos tratados; (ii) Determinação de propriedades fotofísicas e fotoquímicas dos BOS e das espécies reativas que podem ser geradas a partir dessas substâncias; (iii) Uso de BOS para tratamento de efluentes, em particular em processos fotocatalíticos; (iv) Síntese de materiais, a exemplo de seu uso como templates para síntese de dióxido de titânio mesoporoso ou nanopartículas de Ag, Si ou Au. O projeto é coordenado no Brasil pelo Prof. Dr. Galo Antonio C. Leroux e tem a participação do Prof. Dr. Antonio Carlos S. C.Teixeira como pesquisador principal, envolvendo as seguintes Instituições: Universidade de São Paulo (USP), Universidad Politécnica de Valencia (Espanha), Università de Torino (Itália) e Universidad Nacional de La Plata (Argentina). O presente trabalho de Mestrado está inserido no esforço deste projeto. 


\section{MATERIAIS E MÉTODOS}

\subsection{Reagentes}

Utilizou-se água milli-Q (Millipore) no preparo de soluções para obtenção das curvas de calibração cromatográficas. Para a fase móvel foram utilizados: ácido acético 100\% (Merck) e metanol grau HPLC (J.T. Baker). Para os experimentos de degradação, utilizou-se água Milli-Q (MilliPore). Para ajuste do $\mathrm{pH}$ foram utilizadas soluções de ácido sulfúrico 98\% P.A. e de hidróxido de sódio P.A (Vetec). O antibiótico enrofloxacina (ENRO- Enrofloxacin CAS 93106-60-6) (98\%) foi adquirido da Sigma-Aldrich. Amostras de BOS A, B e C (cf. Tabela 4) foram cedidas pelo Grupo de Procesos de Oxidación Avanzada, do Departamento de Ingeniería Textil y Papelera (DITEXPA) da Universitat Politécnica de València (Campus de Alcoy, Espanha), participante do Projeto FP7-PEOPLE-2010-IRSES-Comissão Europeia.

\subsection{Equipamento Experimental}

Os experimentos de fotodegradação foram realizados em um reator fotoquímico tubular de imersão com volume irradiado de 0,85 L, construído em vidro borossilicato, com fonte radiante interna concêntrica ao reator (Figura 6 e Figura 7), conectado a um tanque externo de 1,5 L, cujo conteúdo é agitado por meio de um agitador mecânico (Tecnal, TE139). O equipamento foi operado em batelada com recirculação entre o reator e o tanque, realizada com uma bomba centrífuga. A temperatura do líquido foi mantida a $25^{\circ} \mathrm{C}$ por meio de um banho termostático (Julabo, modelo EC). 


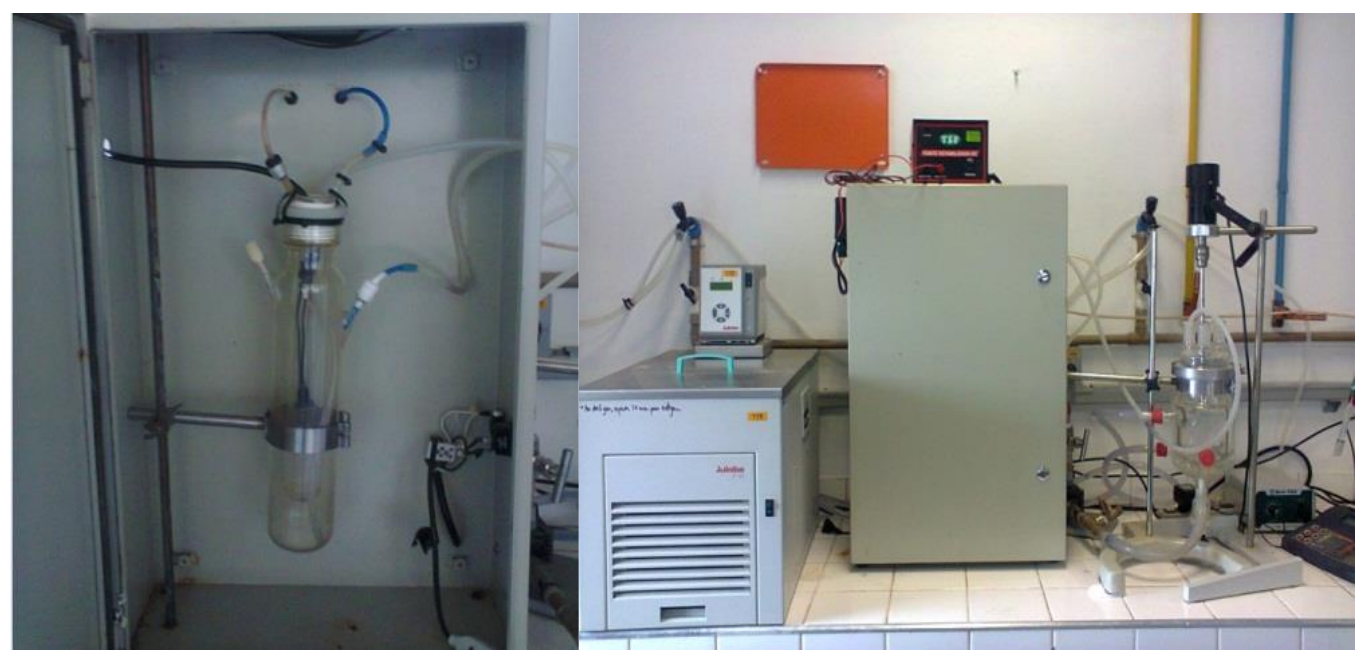

Figura 6: Reator fotoquímico e equipamentos associados.

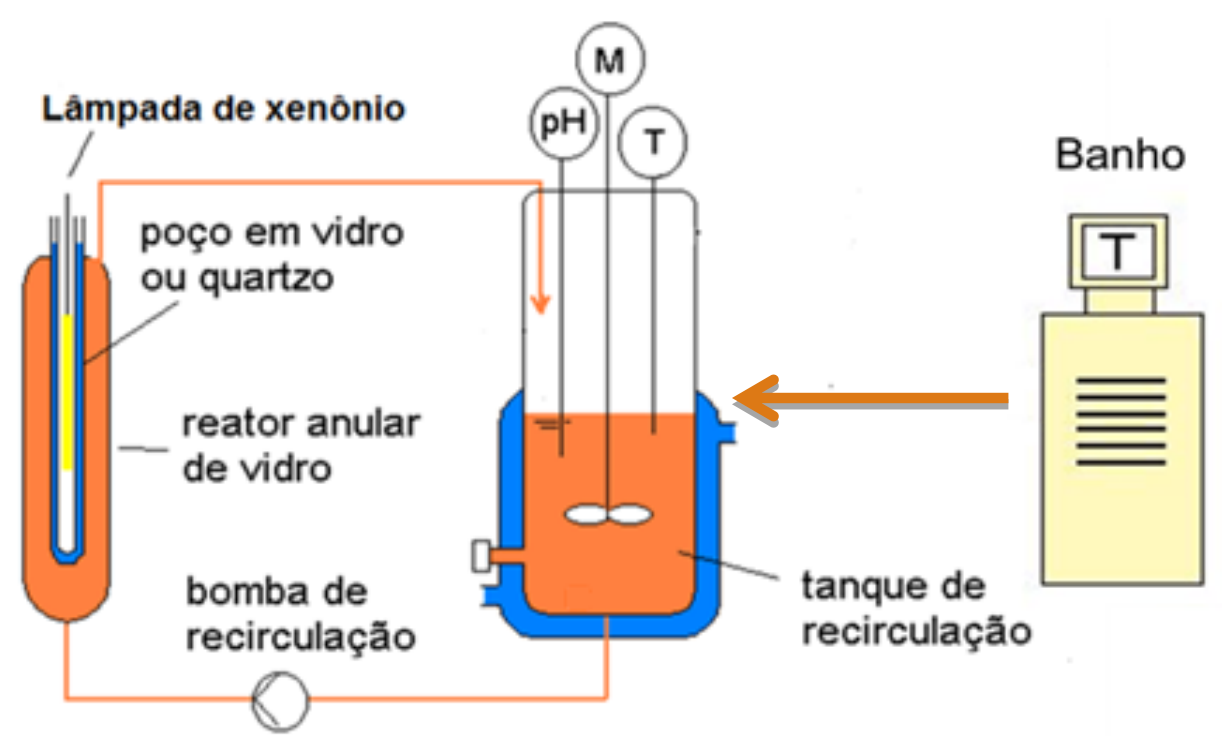

Figura 7 : Esquema do equipamento experimental.

O reator dispõe de uma lâmpada de xenônio (Xenon H27, modelo 10000K) de $35 \mathrm{~W}$, como fonte radiante, disposta no interior de um poço de quartzo. A distribuição espectral da luz emitida pela lâmpada foi medida com um espectrorradiômentro (Luzchem, modelo SPR-4002), a Figura 8 apresenta a intensidade da radiação emitida pela lâmpada de xenônio. A intensidade próxima a zero para comprimentos de onda inferiores a $300 \mathrm{~nm}$ pode ser devido ao bulbo da lâmpada ser confeccionado em vidro e não em quartzo, ou então em quartzo de menor pureza. 


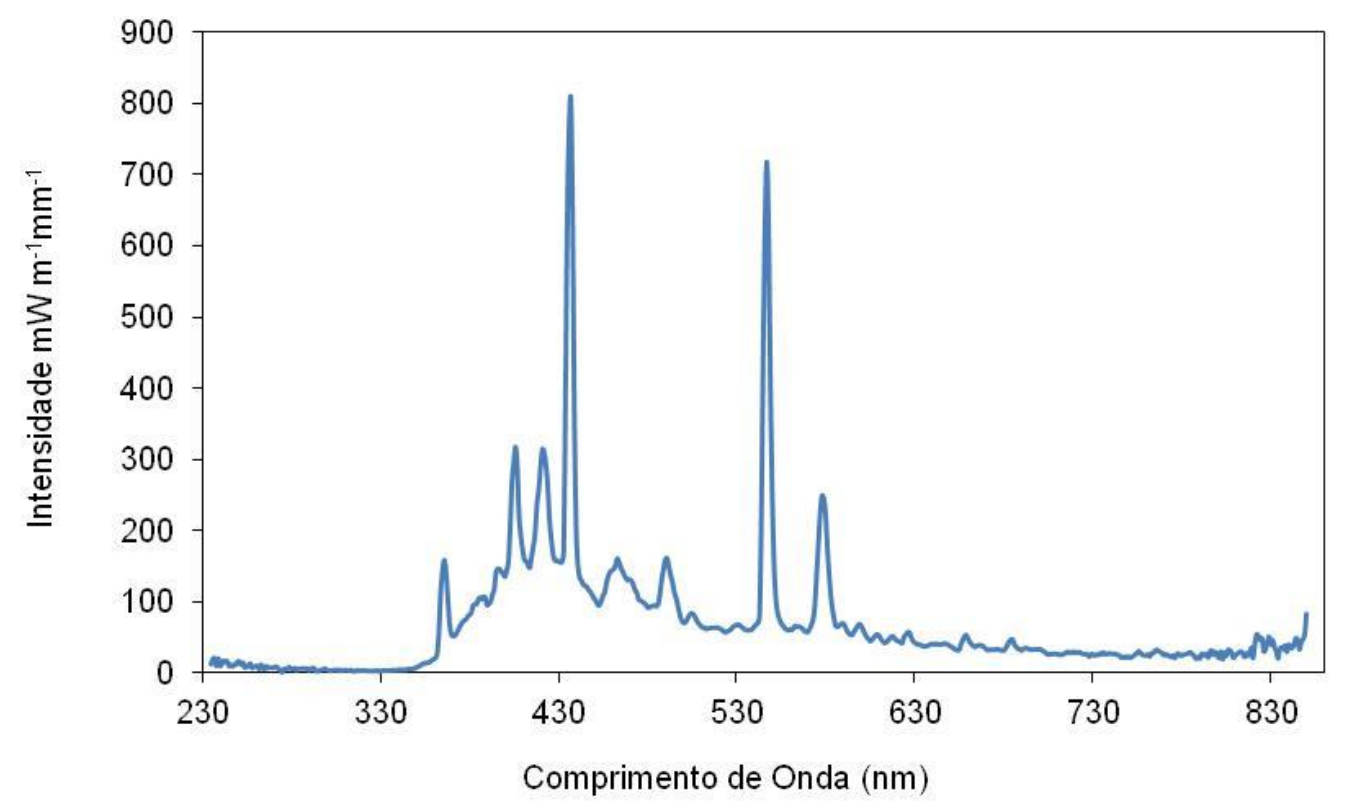

Figura 8 : Espectro de emissão da lâmpada de xenônio (Xenon H27, modelo 10000K), medido com lâmpada inserida em poço de quartzo.

\subsection{Procedimentos}

\subsubsection{Ensaio de Hidrólise da Enrofloxacina em Solução Aquosa}

O ensaio de hidrólise da enrofloxacina (ENRO) foi realizado a $25^{\circ} \mathrm{C}$ para duas concentrações do fármaco (25 e $\left.50 \mathrm{mg} \mathrm{L}^{-1}\right)$ e quatro diferentes valores de $\mathrm{pH}(3,5,7$ e 9), em erlenmeyers de $250 \mathrm{~mL}$ mantidos sob agitação constante de 100 rpm em uma incubadora termostatizada (Tecnal, modelo TE-421). Os experimentos foram realizados em triplicata e as amostras foram retiradas nos tempos $0 \mathrm{~h}, 12 \mathrm{~h}$ e $24 \mathrm{~h}$ e analisadas por cromatografia líquida de alta eficiência (HPLC), conforme descrito posteriormente. 


\subsubsection{Estudo da Fotodegradação da Enrofloxacina}

Neste estudo foram considerados dois processos: fotólise e radiação $\mathrm{H}_{2} \mathrm{O}_{2} /$ UV. Em ambos os casos, avaliou-se efeito da presença de compostos bio-orgânicos (BOS).

Os experimentos para estudo da degradação fotoquímica do antibiótico enrofloxacina (ENRO) foram realizados de acordo com as seguintes etapas:

- Limpeza do reator com água destilada;

- Utilizou-se uma balança analítica (Mettler Toledo, modelo XS205 Dual Range) para pesar a massa do antibiótico e de BOS;

- As massas pesadas de enrofloxacina e BOS foram dissolvidas em água Milli-Q (Millipore) em um balão volumétrico de $2 \mathrm{~L}$, utilizando-se um banho ultrassônico (Fischer Scientific, modelo FS110);

- Para a total solubilização da enrofloxacina, a solução foi acidificada a $\mathrm{pH}=3$ e deixada em um banho ultrassônico durante três horas, sendo em seguida encaminhada ao reator;

- Após preencher o sistema, a bomba foi ligada;

- $\mathrm{O} \mathrm{pH}$ foi ajustado ao valor inicial desejado com solução aquosa de $\mathrm{H}_{2} \mathrm{SO}_{4} 10 \%$ ou solução aquosa de $\mathrm{NaOH} 10 \mathrm{~mol} \mathrm{~L}^{-1}$, conforme o caso;

- O banho termostático foi ligado com o objetivo de manter a solução do fármaco no sistema a $25^{\circ} \mathrm{C}$;

- Com o pH, temperatura e vazão de recirculação constantes, coletouse a amostra inicial;

- Acionou-se a lâmpada e deu-se início à coleta de amostras de $10 \mathrm{~mL}$ a cada 5 minutos, até completar 20 minutos. Na sequência, amostras foram retiradas a cada 10 minutos na primeira hora e em seguida a cada 30 minutos até completar quatro horas de reação. Cada amostra foi filtrada em filtro de membrana de 0,45 $\mu \mathrm{m}$ (Millipore). 
Durante todo o experimento, a temperatura e $\mathrm{pH}$ foram mantidos constantes ao longo do tempo por meio de controle manual;

- As amostras foram caracterizadas segundo as técnicas analíticas descritas posteriormente;

- Ao final do experimento, o conteúdo do reator foi descarregado e foi feita a limpeza do equipamento.

\subsection{Medidas e Análises}

\subsection{1 $\mathrm{pH}$ e temperatura}

$\mathrm{O} \mathrm{pH}$ foi medido utilizando um medidor de $\mathrm{pH}$ (Hanna Instruments), previamente calibrado com soluções-tampão de pH 4,0 e 7,0. Os sensores de $\mathrm{pH}$ e temperatura foram dispostos no tanque de recirculação associado ao reator, para a realização das leituras.

\subsubsection{Espectrofotometria UV-visível}

Os espectros de absorção UV-visível das soluções aquosas foram obtidos em um espectrofotômetro Varian (modelo Cary 50), entre 190 e 600 nm com resolução de $1 \mathrm{~nm}$, utilizando cubetas de quartzo com caminho óptico de $1 \mathrm{~cm}$. Esses espectros foram utilizados para caracterizar o comportamento do fármaco em solução aquosa em diferentes $\mathrm{pH}(3,5,7$ e 9) e para identificar o comprimento de onda mais adequado para análises de cromatografia líquida de alta eficiência (HPLC). Também foram obtidos os espectros de absorção UVvisível do composto bio-orgânico BOS C (CVT230, cf. Tabela 4). 
Para a determinação do coeficiente molar $(\varepsilon)$ da enrofloxacina foram obtidos os espectros de absorção UV-visível para cinco diferentes concentrações do fármaco; o cálculo foi realizado a partir da Lei de Lambert-Beer.

A determinação do $\mathrm{pK}_{\mathrm{a}}$ da enrofloxacina também foi feita a partir dos espectros de absorção UV-visível das soluções de ENRO a diferentes pH (2 a 11). O tratamento dos resultados para cálculo do pKa foi realizado utilizando-se o software Origin 8.0 para cálculo do ponto central da inflexão da curva obtida .

\subsubsection{Tensão superficial}

A tensão superficial de soluções aquosas contendo BOS foi avaliada por meio de um tensiômetro digital (Lauda, modelo TD1) utilizando o método do destacamento do anel de Du Noüy. Foram realizadas pelo menos três medidas para cada concentração de BOS e calculada a média dos valores medidos.

\subsubsection{Cromatografia líquida de alta eficiência}

A oxidação do fármaco durante os processos de degradação foi avaliada por meio do decaimento da concentração de enrofloxacina, a qual foi monitorada pela técnica de Cromatografia Líquida de Alta Eficiência (HPLC) em fase reversa. A metodologia analítica para este trabalho foi desenvolvida em equipamento LCMS-2010 Shimadzu (modelo 10-AD) com detector UV. Os cromatogramas foram analisados por meio do programa computacional LCMS solution, versão 2.04. As análises foram realizadas à temperatura controlada de $40^{\circ} \mathrm{C}$ em coluna Shim-Pack XR-ODS C18 de fase reversa $(2,0 \mathrm{~mm} \times 30 \mathrm{~mm}$; tamanho da partícula de 2,2 $\mu \mathrm{m})$.

A quantificação da enrofloxacina foi realizada utilizando o método isocrático à vazão de $0,2 \mathrm{~mL} \min ^{-1}$, com fase móvel composta de $15 \%$ de metanol e $85 \%$ 
de água Milli-Q acidificada com 1\% de ácido acético grau HPLC; o detector de UV foi usado em $275 \mathrm{~nm}$. O volume injetado de amostra foi igual a $10 \mu \mathrm{L}$; o limite de quantificação obtido para a enrofloxacina foi de $50 \mu \mathrm{g} \mathrm{L}^{-1}$. 


\section{RESULTADOS E DISCUSSÃO}

5.1 Ensaio de Hidrólise da Enrofloxacina

O ensaio de hidrólise da enrofloxacina (ENRO) foi realizado durante um período de 24 horas, com retirada de amostras no tempo zero e após 12 h e 24 h. O ensaio foi realizado a partir de duas concentrações iniciais de ENRO (25 $\mathrm{mg} \mathrm{L}^{-1}$ e $\left.50 \mathrm{mg} \mathrm{L}^{-1}\right)$ em diferentes valores de $\mathrm{pH}(3,5,7$ e 9). Os resultados são apresentados nas Figura 9 e Figura 10 e na Tabela 6.

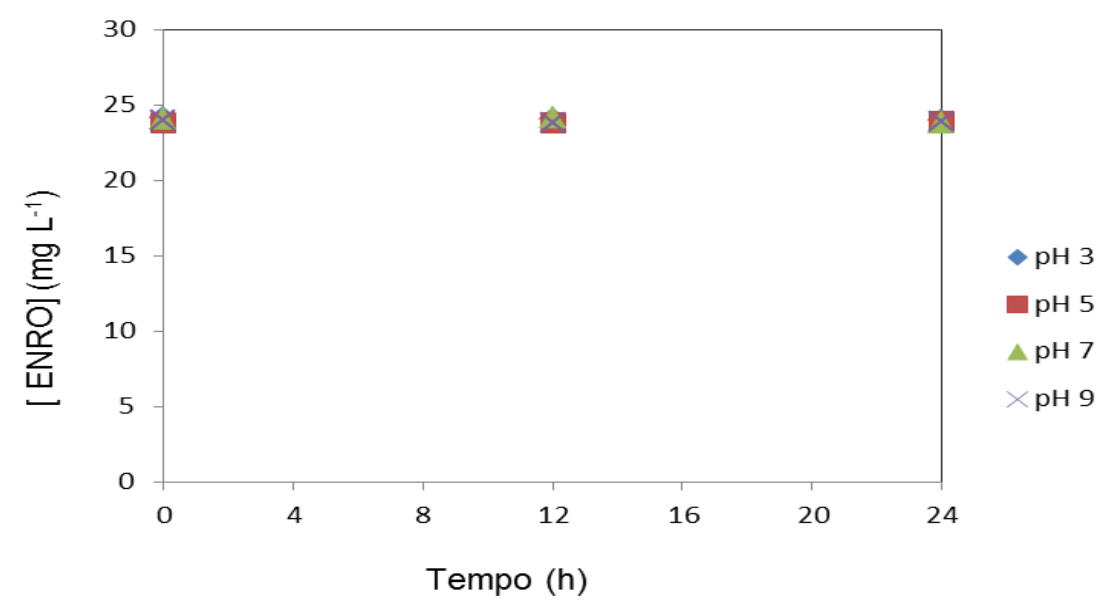

Figura 9 : Resultados do ensaio de hidrólise da enrofloxacina (ENRO) nos diferentes $\mathrm{pH}(3,5,7 \text { e 9) com valores médios das duplicatas para [ENRO }]_{0}=25 \mathrm{mg} \mathrm{L}^{-1}$.

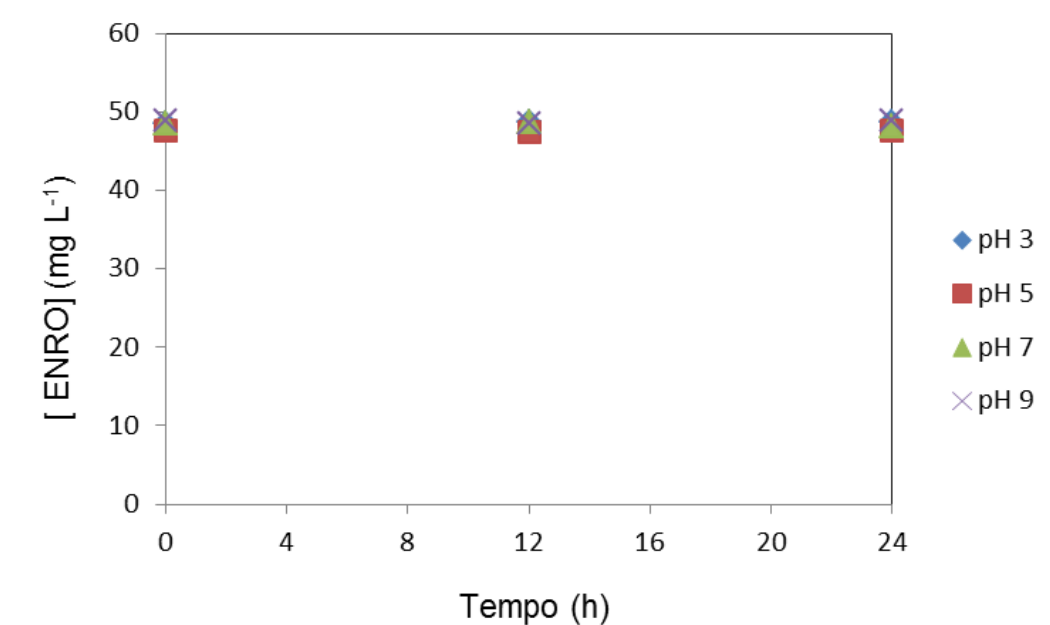

Figura 10 : Resultados do ensaio de hidrólise da enrofloxacina (ENRO) nos diferentes $\mathrm{pH}(3,5,7 \text { e 9) com valores médios das duplicatas para [ENRO }]_{0}=50 \mathrm{mg} \mathrm{L}^{-1}$. 
Tabela 6 : Resultados dos ensaios de hidrólise da enrofloxacina (ENRO) nos diferentes valores de $\mathrm{pH}$.

\begin{tabular}{ccccc}
$\begin{array}{c}\text { Concentração inicial } \\
\text { nominal de ENRO } \\
\left(\mathrm{mg} \mathrm{L}^{-1}\right)\end{array}$ & $\mathrm{pH}$ & \multicolumn{3}{c}{ Concentração real de ENRO $\left(\mathrm{mg} \mathrm{L}^{-1}\right)$} \\
\hline & & $0 \mathrm{~h}$ & $12 \mathrm{~h}$ & $24 \mathrm{~h}$ \\
\cline { 2 - 5 } & 3 & 24,1 & 24,0 & 23,9 \\
& & 24,1 & 23,8 & 23,8 \\
& 5 & 23,8 & 23,9 & 23,7 \\
& & 23,8 & 23,9 & 23,8 \\
& 7 & 24,1 & 23,8 & 24,1 \\
& & 24,1 & 24,0 & 24,2 \\
& 9 & 24,0 & 23,9 & 23,7 \\
& & 23,8 & 23,8 & 23,7 \\
\hline 50 & 3 & 48,5 & 48,7 & 48,8 \\
& & 48,7 & 48,7 & 48,5 \\
& 5 & 47,5 & 47,5 & 47,4 \\
& & 47,4 & 47,7 & 47,6 \\
& & 48,6 & 48,2 & 48,9 \\
& 7 & 48,7 & 48,0 & 49,4 \\
& & 48,8 & 48,8 & 48,9 \\
& 9 & 48,5 & 48,5 & 48,8 \\
\hline
\end{tabular}

Esses resultados permitem observar que, independentemente do valor do $\mathrm{pH}$ e da concentração inicial da enrofloxacina, tanto em meio ácido $(\mathrm{pH} 3,0)$ quanto para meios neutro $(\mathrm{pH} 7,0)$ e básico $(\mathrm{pH} 9,0)$, a solução apresenta estabilidade, não ocorrendo reação de hidrólise da ENRO no tempo total considerado.

O fato de não ocorrer hidrólise no período 24 horas permite concluir que a degradação da ENRO durante a fotólise nos experimentos realizados neste trabalho tem como único responsável a interação da radiação UV-visível com o fármaco e o composto bio-orgânico, quando empregado. Em relação à degradação no meio ambiente, o fato do antibiótico enrofloxacina não sofrer hidrólise está de acordo com o apontado por SARMAH et al. (2006) e BOXALL et al. (2002), que relatam que a meia vida da ENRO é maior que 30 dias e ressaltam sua persistência após ser lançada no ambiente aquático e no solo. 
5.2 Avaliação Espectrofotométrica da Enrofloxacina em Solução Aquosa

Os espectros de absorção UV-visível da enrofloxacina em solução aquosa, nos diferentes valores de $\mathrm{pH}$ e de concentrações, ajudam a avaliar a sobreposição com os espectros de emissão da lâmpada empregada nos experimentos de fotólise e também a influência do $\mathrm{pH}$ durante esse fenômeno.

As Figura 12 mostram que a absorção da ENRO depende do $\mathrm{pH}$, com absorção máxima próxima de $275 \mathrm{~nm}$, que corresponde ao menor comprimento de onda em que a lâmpada de xenônio empregada no trabalho emite. Dessa forma, as moléculas de ENRO absorveriam fótons mais intensamente nesse comprimento de onda, o que foi avaliado calculando-se o coeficiente de absorção molar (Tabela 7).

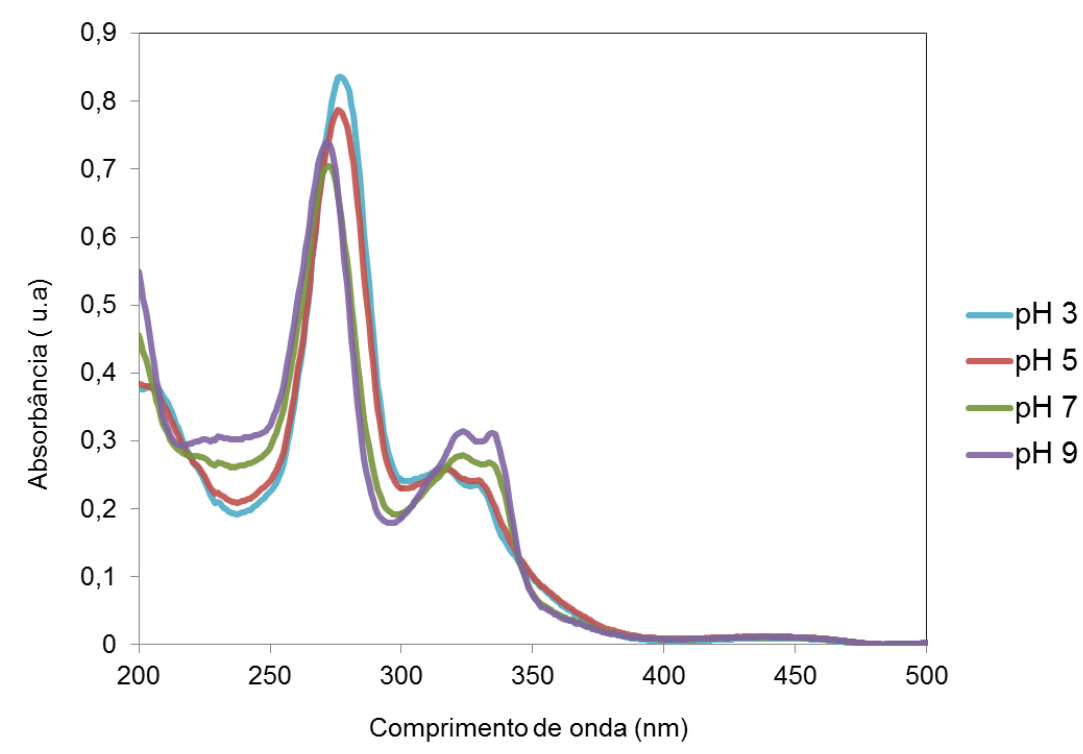

Figura 11 : Espectros de absorção UV-visível da enrofloxacina (ENRO) em solução aquosa à concentração de $5 \mathrm{mg} \mathrm{L}^{-1}$ em diferentes $\mathrm{pH}(35,7$ e 9). Varredura de 190 a $450 \mathrm{~nm}$, com resolução de $1 \mathrm{~nm}$ e caminho ótico de $1 \mathrm{~cm}$. 


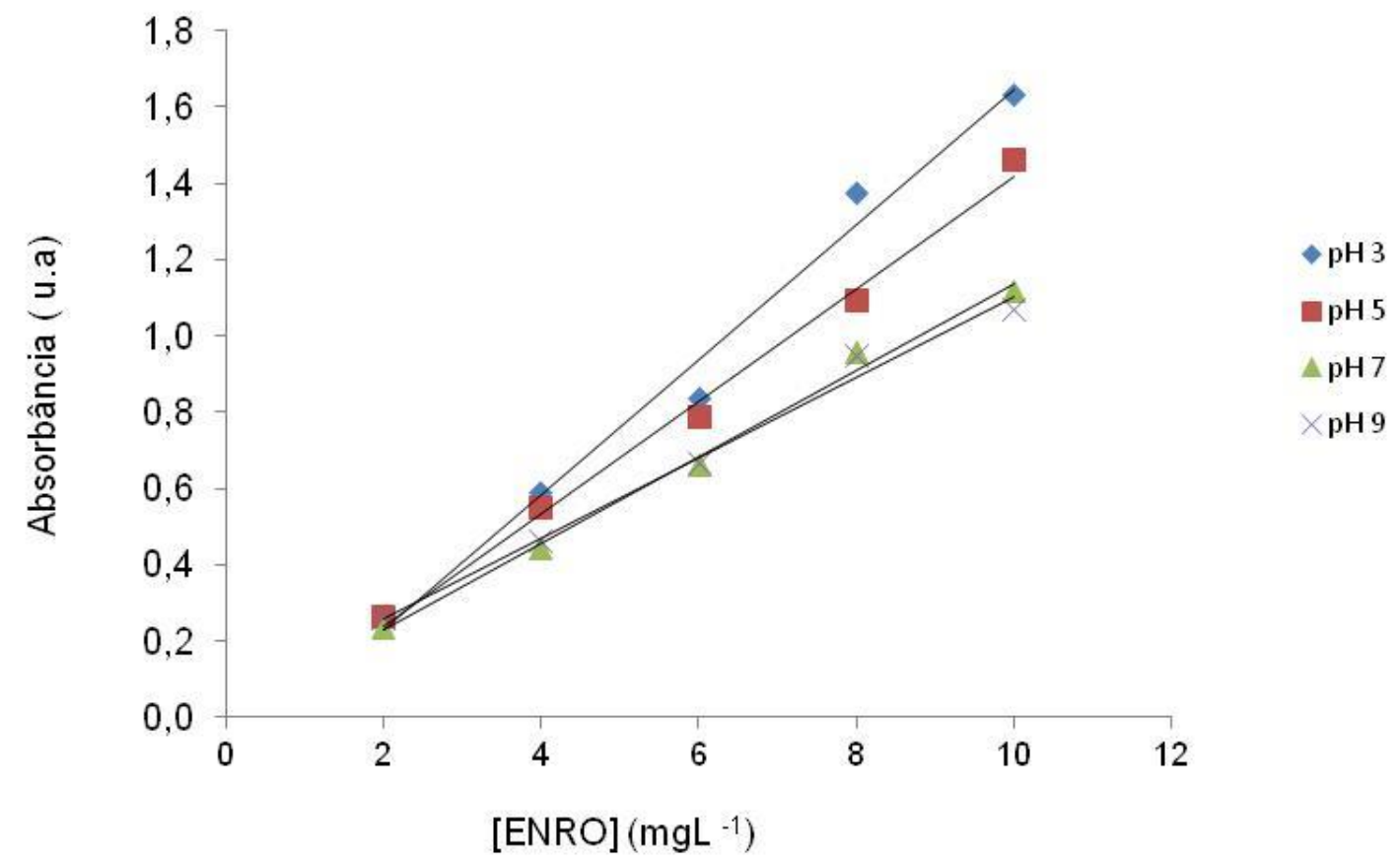

Figura 12 : Absorbância de enrofloxacina em solução aquosa em diferentes concentrações. Espectros de absorção medidos com resolução de $1 \mathrm{~nm}$ em $275 \mathrm{~nm}$.

As equações das retas ajustadas aos pontos da Figura 12 e os valores dos coeficientes de determinação $R^{2}$ estão apresentados na Tabela 7 .

Tabela 7 : Equações dos ajustes lineares de absorbância (abs) em 275 nm em função da concentração de ENRO a diferentes valores de $\mathrm{pH}$ e valores de $R^{2}$ correspondentes.

\begin{tabular}{crc}
\hline $\mathbf{p H}(\mathbf{2 7 5} \mathbf{n m})$ & Equação da reta & $\boldsymbol{R}^{2}$ \\
\hline $\mathbf{3}$ & $a b s=0,177 \times[$ ENRO $]$ & 0,9856 \\
$\mathbf{5}$ & $a b s=0,147 \times[$ ENRO $]$ & 0,9943 \\
$\mathbf{7}$ & $a b s=0,114 \times[$ ENRO $]$ & 0,9941 \\
$\mathbf{9}$ & $a b s=0,105 \times[$ ENRO $]$ & 0,9900 \\
\hline
\end{tabular}

O valor do coeficiente de absorção molar da ENRO em $275 \mathrm{~nm}$ foi calculado pela Equação 13, conforme a Lei de Beer-Lambert:

$a b s_{275}=\varepsilon_{275} \times C \times 1$

Em que:

$\varepsilon=$ coeficiente de absorção molar $\left(\mathrm{L} \mathrm{mol}^{-1} \mathrm{~cm}^{-1}\right)$; 
$\mathrm{C}=$ concentração do composto $\left(\mathrm{mol} \mathrm{L}^{-1}\right)$;

$\mathrm{L}=$ comprimento do caminho óptico da cubeta $(1 \mathrm{~cm})$.

Conforme a Figura 12, a absorção do antibiótico depende do pH, sendo a maior absorção de radiação UV em $275 \mathrm{~nm}$, obtendo-se os valores de $\varepsilon_{275}=63600 \mathrm{~L} \mathrm{~mol}^{-1} \mathrm{~cm}^{-1}(\mathrm{pH} 3), \varepsilon_{275}=52800 \mathrm{~L} \mathrm{~mol}^{-1} \mathrm{~cm}^{-1}(\mathrm{pH} 5), \varepsilon_{275}=40800 \mathrm{~L}$ $\mathrm{mol}^{-1} \mathrm{~cm}^{-1}\left(\mathrm{pH}\right.$ 7) e $\varepsilon_{275}=37800 \mathrm{~L} \mathrm{~mol}^{-1} \mathrm{~cm}^{-1}(\mathrm{pH}$ 9). É possível observar que o valor do coeficiente de absorção molar em $275 \mathrm{~nm}$ diminui com o aumento do $\mathrm{pH}$, com redução de aproximadamente $40 \%$ entre pH 3 e pH 9 (Figura 13).

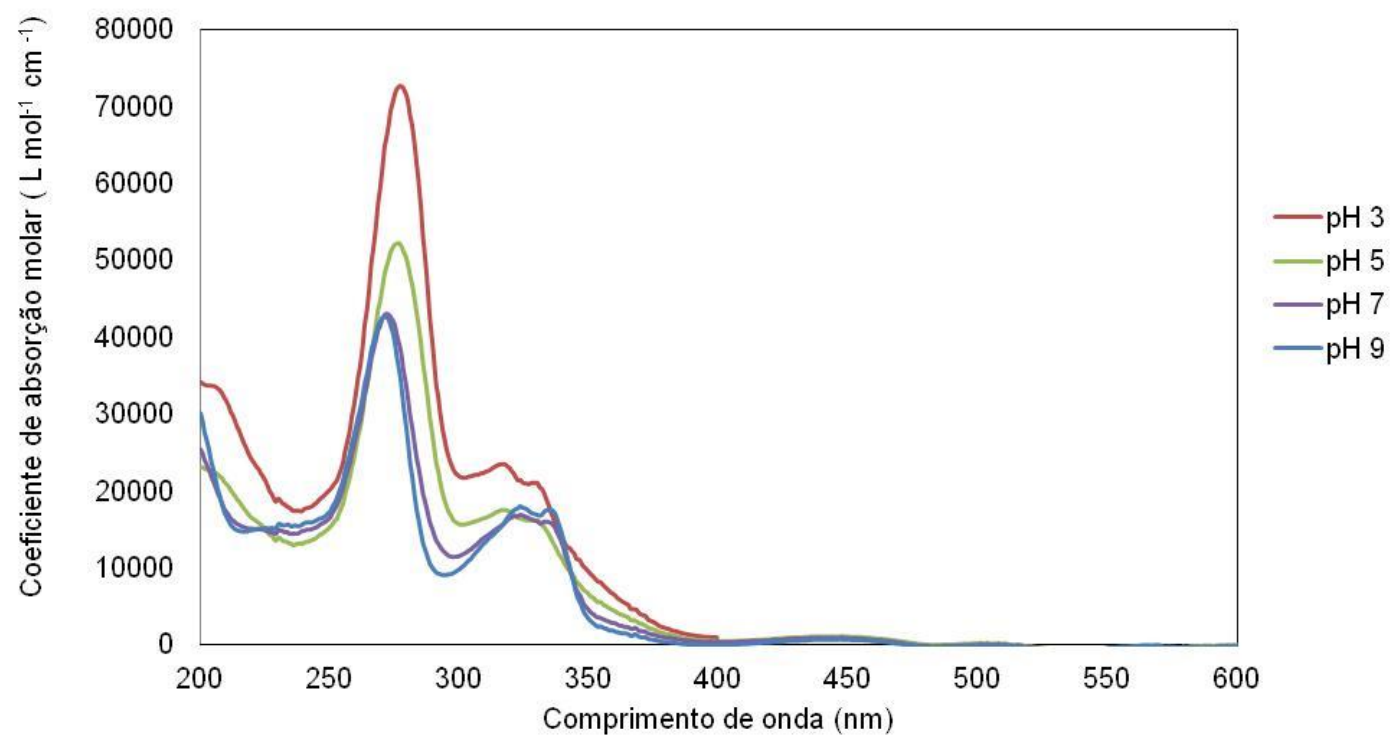

Figura 13 : Distribuição espectral do coeficiente de absorção molar da enrofloxacina em solução aquosa em diferentes pH. Espectros de absorção medidos com resolução de $1 \mathrm{~nm}$. 
5.3 Obtenção do pKa de Soluções Aquosas de Enrofloxacina

As fluoroquinolonas com o grupo piperazilo apresentam dois valores de $\mathrm{pK}_{\mathrm{a}}$ característicos, o primeiro em torno de $\mathrm{pH}$ 5,2 e o outro próximo de $\mathrm{pH}$ 9,6 (CHEMICALIZE, 2013), existindo em sua maior parte, na forma catiônica em meio ácido, na forma aniônica em meio básico e na forma zwitteriônica em meio neutro. Dessa forma, a molécula apresenta em geral carga zero, mas possui zonas com carga positiva e outras com carga negativa, sendo solúvel em água, mas pouco solúvel em soluções orgânicas (Figura 14) (BUGYEI et al., 1999; PISTOS et al., 2005).

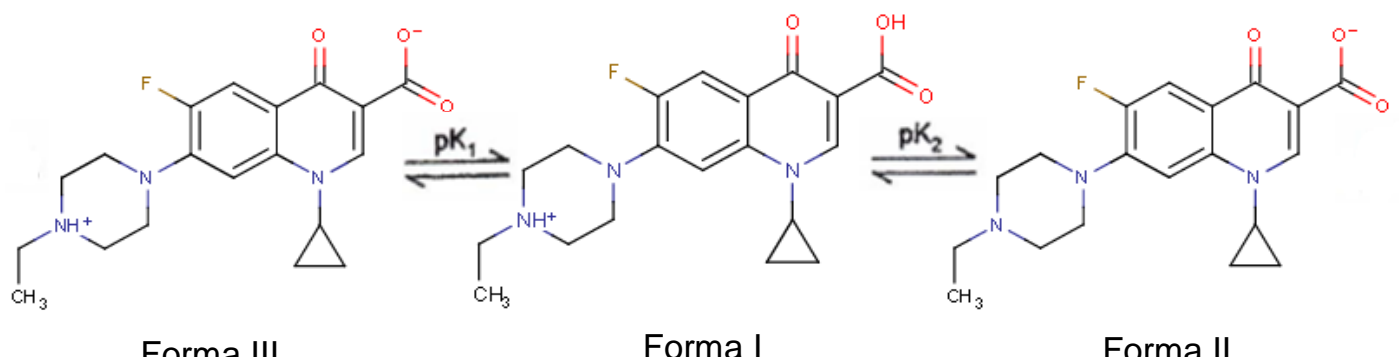

Forma III

Forma I

Forma II

Figura 14 : Comportamento ácido-base da enrofloxacina (CHEMICALIZE, 2013).

A obtenção experimental de $\mathrm{pK}_{\mathrm{a}}$ foi realizada a partir da solução aquosa do antibiótico ([ENRO]=5 $\mathrm{mg} \mathrm{L}^{-1}$ ) para dez valores de $\mathrm{pH}$ diferentes, entre 2 e 11. Na Figura 15 é possível observar que em meio ácido, há uma banda de absorção no UV com o máximo em $275 \mathrm{~nm}$. À medida que o pH aumenta, a banda se desloca para comprimentos de ondas menores, como comentado anteriormente, como resultado da desprotonação da molécula. Também há um deslocamento da banda em $330 \mathrm{~nm}$ para o vermelho. Dessa forma, em meio básico, a banda é verificada em cerca de $335 \mathrm{~nm}$. Observa-se que o sistema possui três isosbésticos, mas apenas um é bem definido em $345 \mathrm{~nm}$. 


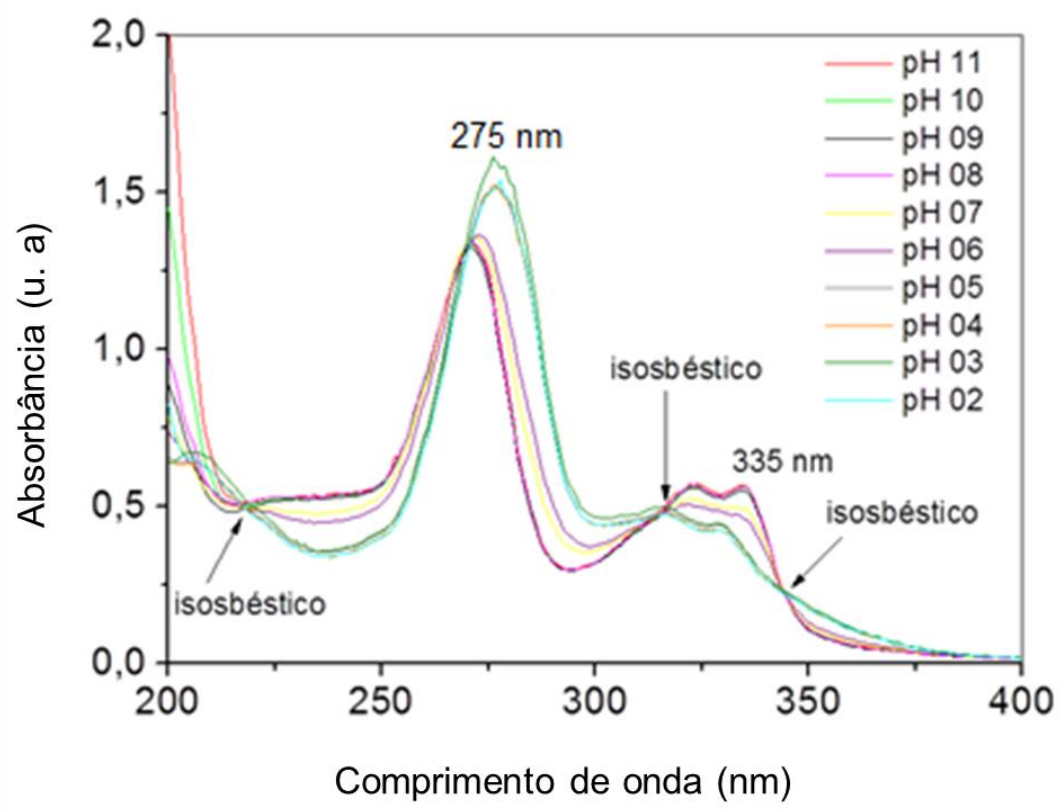

Figura 15 : Obtenção experimental do pKa da enrofloxacina em solução aquosa.

Para determinar o valor de $\mathrm{pK}_{\mathrm{a}}$, foi gerado um gráfico da absorbância para o comprimento de onda em que se verificou o máximo correspondente à forma desprotonada (meio ácido, $335 \mathrm{~nm}$ ). Obtiveram-se os ajustes dos dados experimentais por uma curva sigmoidal utilizando o programa Origin 8.0 (Figura 16). $\mathrm{O} \mathrm{pK}_{\mathrm{a}}$ foi estimado como o valor de $\mathrm{pH}$ correspondente à inflexão da curva sigmoidal, em $\mathrm{pH}=6,3$. Para esse valor, coexistem principalmente três formas da enrofloxacina em solução aquosa ( $57 \%$ da forma II, $21,5 \%$ da forma I e $21,5 \%$ da forma III, cf. Figura 14) (Chemicalize, 2013). O método experimental, porém, não permitiu a determinação de todos os valores de pKa. 


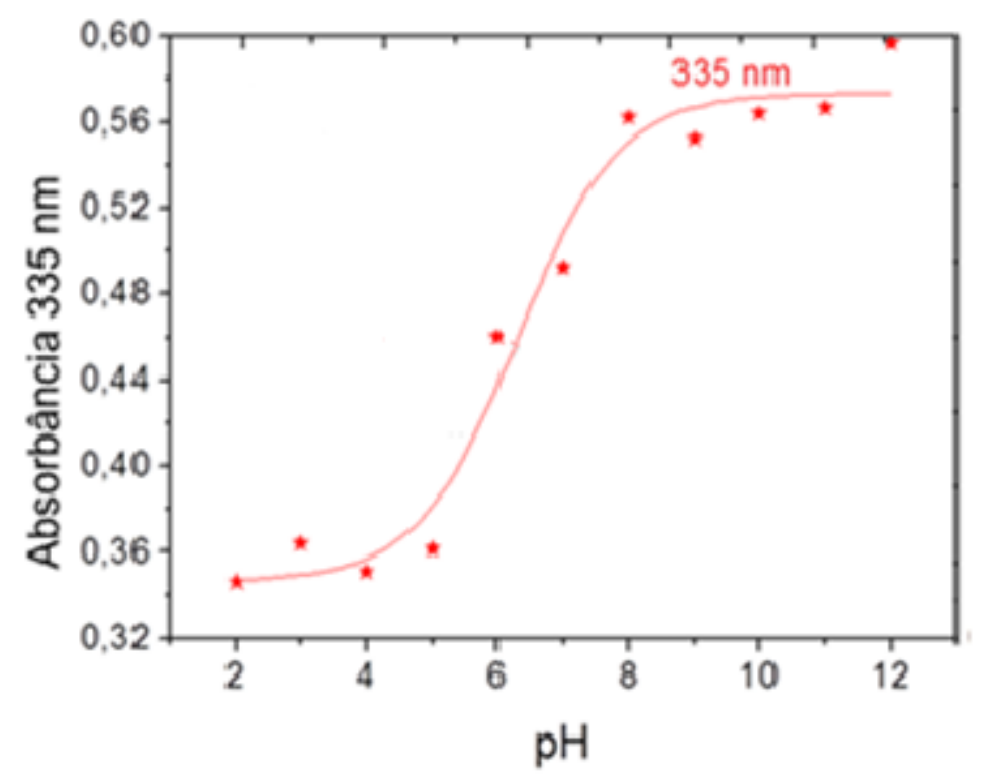

Figura 16 : Estimativa de $\mathrm{pK}_{\mathrm{a}}$ para a enrofloxacina em solução aquosa.

A obtenção do $\mathrm{pK}_{\mathrm{a}}$ permite melhor entendimento do comportamento químico do antibiótico em ambientes naturais, pois o valor do $\mathrm{pH}$ no meio ambiente varia entre 6 e 9, modificando a absorção da radiação UV pela ENRO, já que cada forma (I, II ou III, Figura 14) pode apresentar coeficiente de absorção molar diferente em dada faixa de comprimento de onda, como discutido na seção 5.3. Contudo, como descrito na literatura (PEREIRA, 2011), a degradação do fármaco no meio ambiente não está relacionada somente à fotólise direta, mas também a outros fatores como à degradação química, fotólise indireta pormovida por espécies presentes no ambiente aquático natural e suas propriedades físico-químicas também estão envolvidas. 
5.4 Medida de Tensão Superficial de Soluções de BOS

A principal propriedade dos agentes tensoativos é a redução da tensão superficial do líquido. Neste trabalho foi medida a tensão superficial de soluções aquosas dos compostos bio-orgânicos (BOS) A, B e C (cf. Tabela 4) em $\mathrm{pH}$ 5; este $\mathrm{pH}$ foi adotado para permitir melhor solubilização dos BOS. Os resultados são apresentados na Figura 17.

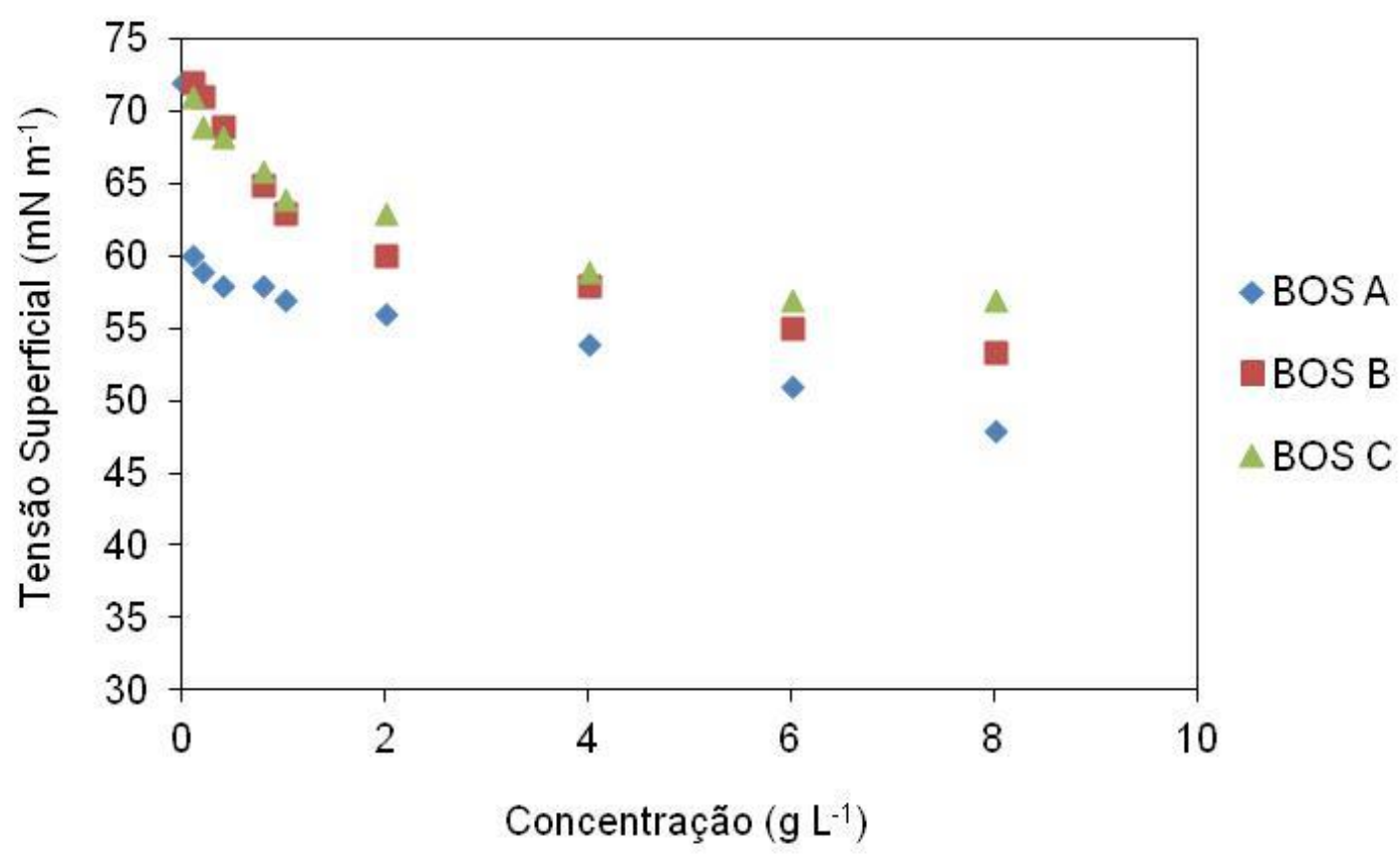

Figura 17 : Tensão superficial dos compostos bio-orgânicos (BOS) a $25^{\circ} \mathrm{C}$ em pH 5.

Estas medidas permitem avaliar a capacidade das moléculas dos BOS em aumentar a solubilidade de compostos hidrofóbicos em água. Como esperado, a Figura 17 mostra que quanto maior a concentração de BOS, menor a tensão superficial da solução para todos os compostos avaliados; a queda da tensão superficial é acentuada até [BOS] por volta de $2 \mathrm{~g} \mathrm{~L}^{-1}$, seguida por uma queda mais suave para concentrações maiores de BOS. Para uma mesma concentração, a tensão superficial apresenta a tendência BOS C (CVT230) > BOS B (CVDTFT110) > BOS A (FORSUD), de modo que este último apresenta 
as melhores propriedades como surfactante. De fato, o BOS A (FORSUD) apresenta a maior razão entre o total de carbonos alifáticos (Af) e aromáticos (Ar), com $A f / A r=3,3$, quando comparado ao BOS B $(A f / A r=1,3)$ e BOS $C$ (Af/Ar=1,8); o BOS A apresenta tambémo maior valor do balanço lipofílicohidrofílico em termos do carbono orgânico total, com $L H=9,3$, quando comparado ao BOS B $(\mathrm{LH}=5,3)$ e BOS C ( $\mathrm{LH}=3,6)$ (ENVIRONBOS, 2013). A Tabela 4 mostra também que o BOS $A$ apresenta a menor relação carbono/nitrogênio em massa $(\mathrm{C} / \mathrm{N})(5,73)$, contra os valores de 8,17 e 9,54 obtidos para o BOS B e o BOS $\mathrm{C}$, respectivamente, devido à maior presença de grupos amida.

Os compostos bio-orgânicos A, B e C apresentam resistência à solubilização com o aumento da concentração; nestas soluções ocorre a variação de $\mathrm{pH}$, havendo necessidade de correção do mesmo para pH 5,0. Os compostos BOS A e BOS B apresentam menor solubilidade se comparados com o BOS C. Pela Figura 17 pode-se calcular a concentração micelar crítica (CMC) de aproximadamente $1,5 \mathrm{~g} \mathrm{~L}^{-1}$; no entanto, neste trabalho foi utilizada a concentração de $20 \mathrm{mg} \mathrm{L}^{-1}$ que é muito inferior à $C M C$.

5.5 Estudo da Degradação da Enrofloxacina por Fotólise em Solução Aquosa

O estudo da degradação da enrofloxacina por fotólise foi realizado em solução aquosa contendo inicialmente $50 \mathrm{mg} \mathrm{L}^{-1}$ do antibiótico. Para este estudo foram realizados 16 experimentos utilizando-se a lâmpada de xenônio de $35 \mathrm{~W}$, em diferentes $\mathrm{pH}$ (mantidos constantes em 3, 5, 7 e 9), na ausência e na presença de diferentes tipos de compostos bio-orgânicos (BOS), identificados como A, B e C (cf. Tabela 4), à concentração de $20 \mathrm{mg} \mathrm{L}^{-1}$. Os experimentos foram divididos em quatro conjuntos independentes: no primeiro, irradiou-se a solução aquosa contendo somente a enrofloxacina (ENRO) (experimentos realizados em triplicata); no segundo, irradiou-se a solução contendo ENRO e BOS A; no terceiro, irradiou-se a solução contendo ENRO e BOS B; no quarto, irradiou-se a solução contendo ENRO e BOS C 
(experimentos realizados em triplicata). Durante os experimentos a solução adquiriu coloração castanha quando adicionado o composto bio-orgânico, mantendo-se, porém, límpida.

A Tabela 8 indica que em todos os experimentos obteve-se degradação da ENRO, sendo a maior degradação do antibiótico identificada quando adicionado BOS C à solução de ENRO em pH 7, com cerca de $87 \%$ de remoção em relação à concentração inicial no período de 240 minutos; também nesta condição foi observada a maior taxa inicial de remoção do antibiótico $\left(0,73 \mathrm{mg} \mathrm{L}^{-1} \mathrm{~min}^{-1}\right)$.

Tabela 8 : Resultados dos experimentos de fotólise de ENRO solução aquosa.

\begin{tabular}{cccccc}
\hline Exp & BOS & $\begin{array}{c}\text { [ENRO] } \\
\left(\mathbf{m g ~ L}^{-1}\right)\end{array}$ & $\mathbf{p H}^{(\mathrm{a})}$ & $\begin{array}{c}\text { Remoção } \\
\text { ENRO (c) } \\
(\%)\end{array}$ & $\begin{array}{c}\text { Tempo (min) para } \\
\text { remoção de 50\% } \\
\text { da concentração } \\
\text { inicial }\end{array}$ \\
\hline I & - & $48,4 \pm 2,70$ & 3 & $9,8 \pm 0,01$ & $\mathrm{~N}$ \\
II & - & $48,0 \pm 8,10$ & 5 & $17,2 \pm 0,10$ & $\mathrm{~N}$ \\
III & - & $48,3 \pm 3,47$ & 7 & $12,6 \pm 0,07$ & $\mathrm{~N}$ \\
IV & - & $47,9 \pm 2,75$ & 9 & $8,2 \pm 0,05$ & $\mathrm{~N}$ \\
\hline 1 & & 48,7 & 3 & 5,9 & $\mathrm{~N}$ \\
2 & $\mathrm{~A}$ & 48,6 & 5 & 6,3 & $\mathrm{~N}$ \\
3 & & 48,5 & 7 & 4,5 & $\mathrm{~N}$ \\
4 & & 48,5 & 9 & 5,6 & $\mathrm{~N}$ \\
\hline 5 & & 49,5 & 3 & 9,2 & $\mathrm{~N}$ \\
6 & $\mathrm{~B}$ & 49,1 & 5 & 18,3 & $\mathrm{~N}$ \\
7 & & 49,1 & 7 & 8,8 & $\mathrm{~N}$ \\
8 & & 49,3 & 9 & 6,3 & $\mathrm{~N}$ \\
\hline 9 & & $47,9 \pm 5,41$ & 3 & $64,4 \pm 0,05$ & 150 \\
10 & $\mathrm{C}$ & $48,1 \pm 2,45$ & 5 & $77,8 \pm 0,01$ & 120 \\
11 & & $49,0 \pm 3,16$ & 7 & $87,0 \pm 0,02$ & 90 \\
12 & & $49,0 \pm 3,12$ & 9 & $57,6 \pm 0,03$ & 210 \\
\hline
\end{tabular}

(a) $\mathrm{pH}$ controlado. ${ }^{(b)}$ Valores reais de [ENRO] $]_{0}$ conforme a calibração cromatográfica realizada. (c) Remoção após 240 minutos de exposição à radiação a lâmpada de xenônio. N: não foi obtida remoção de $50 \%$ nos 240 minutos de irradiação. Experimentos I-IV e 9-12 realizados em triplicata. 
A Figura 18 apresenta a comparação dos experimentos I-IV, realizados na ausência de BOS, em que se observa que a fotólise foi pouco importante nos diferentes $\mathrm{pH}(3,5,7$ e 9), atingindo um máximo de $20 \%$ ao final de 240 minutos de irradiação com a lâmpada de xenônio empregada (35 W) para o experimento $B(\mathrm{pH} 7)$. YANG et al. (2011), partindo de soluções contendo 50 $\mathrm{mg} \mathrm{L}^{-1}$ de ENRO, obtiveram remoção de $58,9 \%$ do fármaco após 90 minutos de irradiação com uma lâmpada de xenônio de 500 W. Esse resultado é qualitativamente consistente com o obtido neste trabalho e indica que a fotólise direta do antibiótico é um processo pouco eficiente e de alta demanda energética, mesmo observando que o coeficiente de absorção molar da ENRO apresenta valores altos entre 300-400 nm (por exemplo, 18000-25000 $\mathrm{L} \mathrm{mol}^{-1}$ $\mathrm{cm}^{-1} \mathrm{em} 330 \mathrm{~nm}$ ), como mostra a Figura 13.

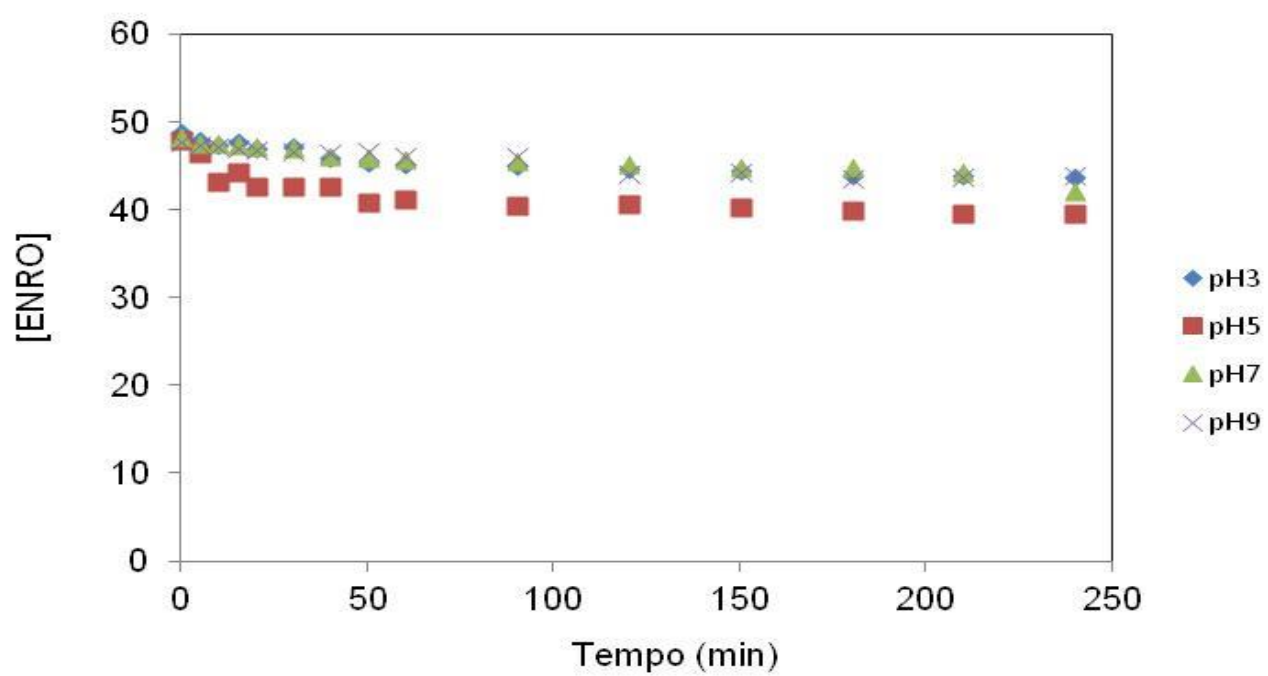

Figura 18 : Resultados dos experimentos de fotólise da ENRO em pH 3 na ausência de BOS (experimento I), 5 (experimento II), 7 (experimento III) e 9 (experimento IV). Condições: $[E N R O]_{0}=50 \mathrm{mg} \mathrm{L}^{-1}$; lâmpada de xenônio de $35 \mathrm{~W} ; 25^{\circ} \mathrm{C}$.

A Figura 19 apresenta os valores médios de [ENRO] para cada tempo correspondentes aos experimentos I-IV realizados em triplicata, a fim de avaliar sua reprodutibilidade, sendo calculadas as médias dos experimentos, em que 0 desvio relativo médio é de $2,7 \%$ para os experimentos realizados em $\mathrm{pH} 3$; $8,1 \%$ para os experimentos realizados em $\mathrm{pH} 5 ; 3,74 \%$ para os experimentos realizados em $\mathrm{pH} 7$ e de $2,75 \%$ para os experimentos realizados em $\mathrm{pH} 9$. 

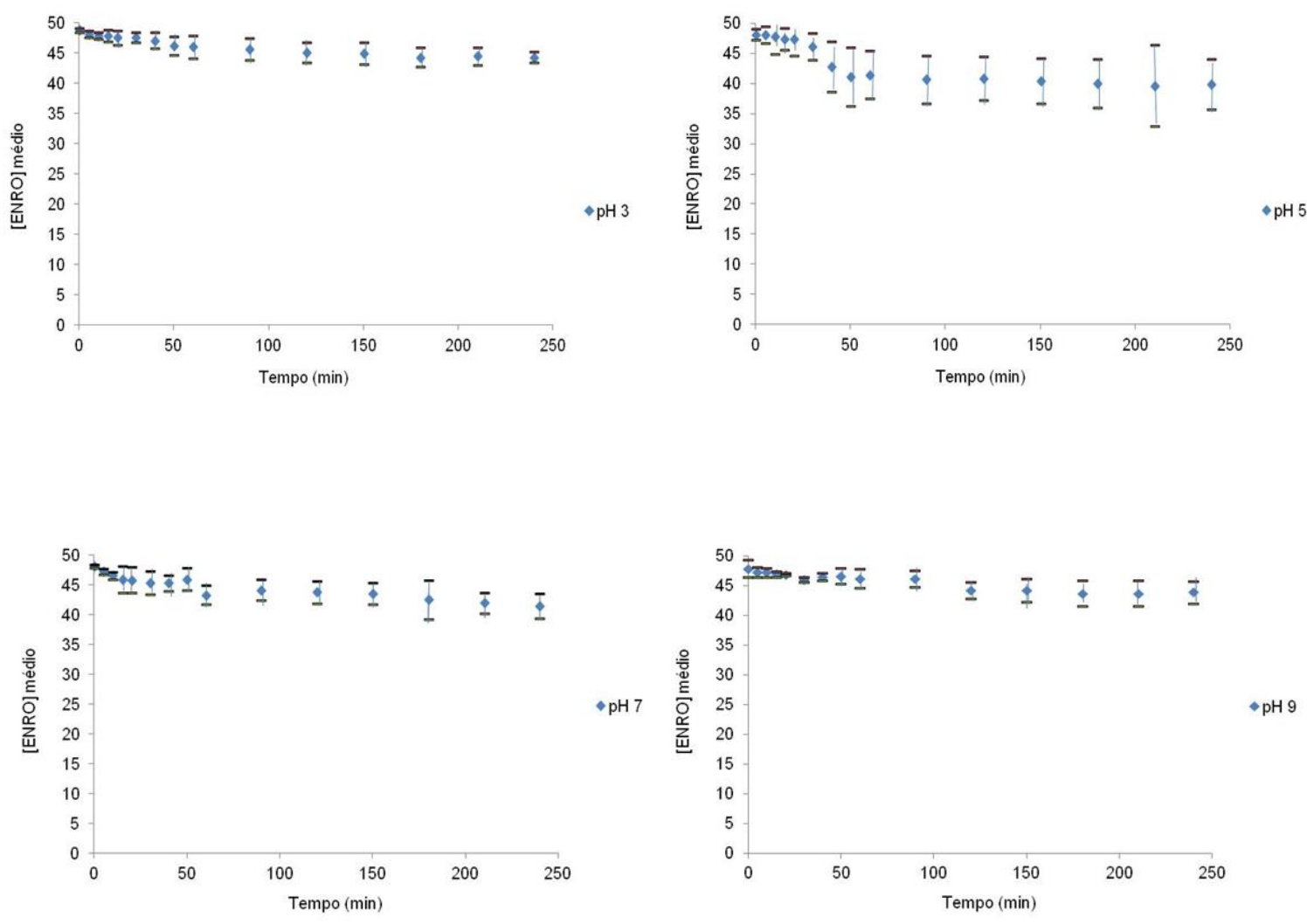

Figura 19 : Resultados dos experimentos de fotólise da ENRO em pH 3, 5, 7 e 9, com indicação do erro experimental em cada tempo. Condições: [ENRO $]_{0}=50 \mathrm{mg} \mathrm{L}^{-1}$; lâmpada de xenônio de $35 \mathrm{~W} ; 25^{\circ} \mathrm{C}$.

Na sequência, foi estudada a degradação da enrofloxacina nos diferentes $\mathrm{pH}$ na presença de compostos bio-orgânicos (BOS A, B e C). Os BOS apresentam estrutura similar à de ácidos húmicos e fúlvicos que absorvem radiação UV-visível com comprimento de onda superior a $300 \mathrm{~nm}$, dando origem a espécies reativas como oxigênio singlete $\left({ }^{1} \mathrm{O}_{2}\right)$ e radicais hidroxila $\left(\mathrm{HO}^{\circ}\right)$, responsáveis pelo ataque às moléculas do fármaco e de seus subprodutos orgânicos (GE et al., 2009).

A adição dos compostos bio-orgânicos teve o intuito de identificar efeitos que estes pudessem exercer sobre a fotólise da ENRO em solução aquosa. Os experimentos realizados com BOS A (FORSUD) e BOS B (CVDFT110) não apresentaram degradações significativas do antibiótico, sendo os valores médios da remoção de ENRO após 240 minutos na presença de BOS A e de BOS B iguais a 5,6\% e 10,6\%, respectivamente. Esse comportamento pode ser observado através dos resultados apresentados na Tabela 8 e nas Figura 20 e 
Figura 21. Os conjuntos de experimentos 1-4 e 5-8 não foram repetidos sistematicamente em triplicada, uma vez que algumas repetições realizadas indicaram o mesmo comportamento, com remoções de ENRO não maiores que ca. $10 \%$.

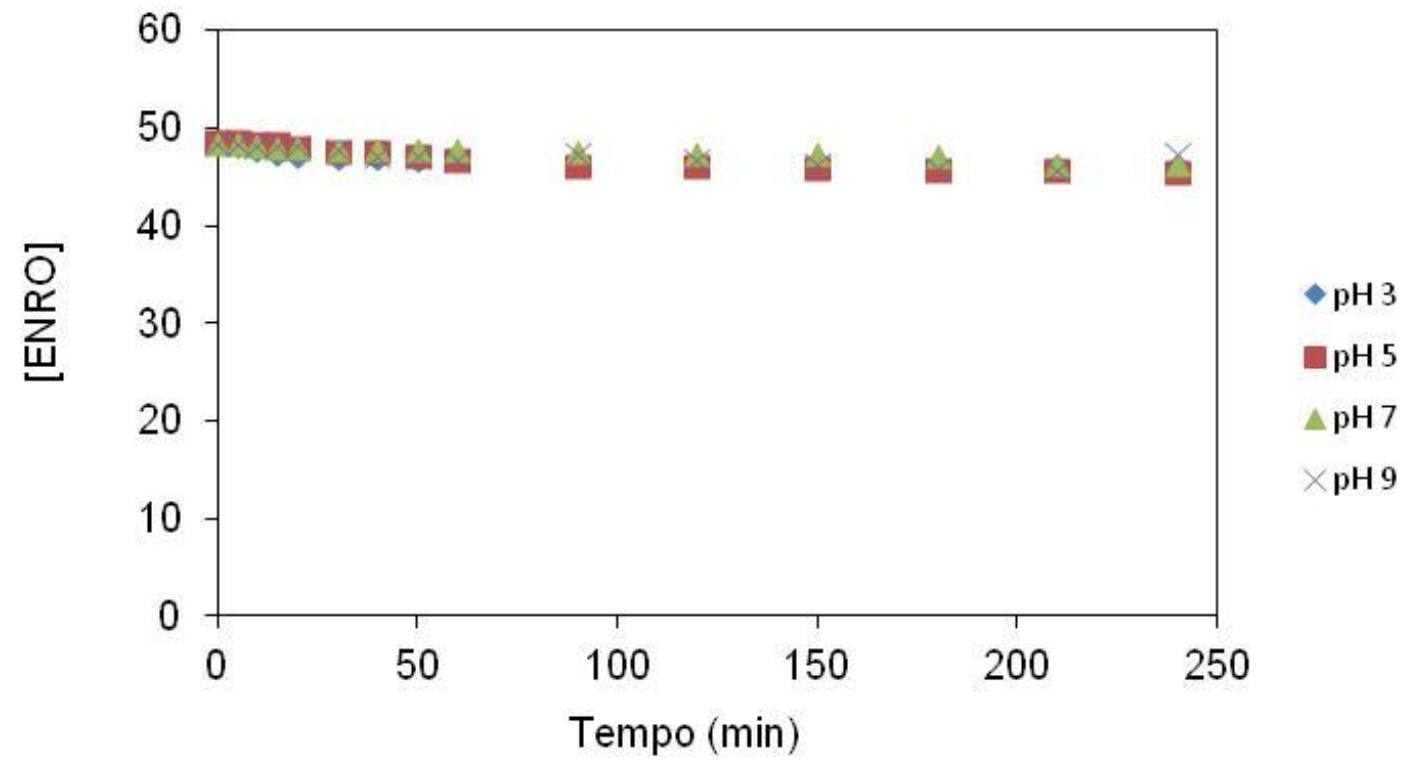

Figura 20 : Resultados dos experimentos de fotólise da ENRO em pH 3, 5, 7 e 9 na presença de BOS A (FORSUD). Condições: [ENRO $]_{0}=50 \mathrm{mg} \mathrm{L}^{-1}$; [BOS A $]_{0}=20 \mathrm{mg} \mathrm{L}^{-1}$; lâmpada de xenônio de $35 \mathrm{~W} ; 25^{\circ} \mathrm{C}$.

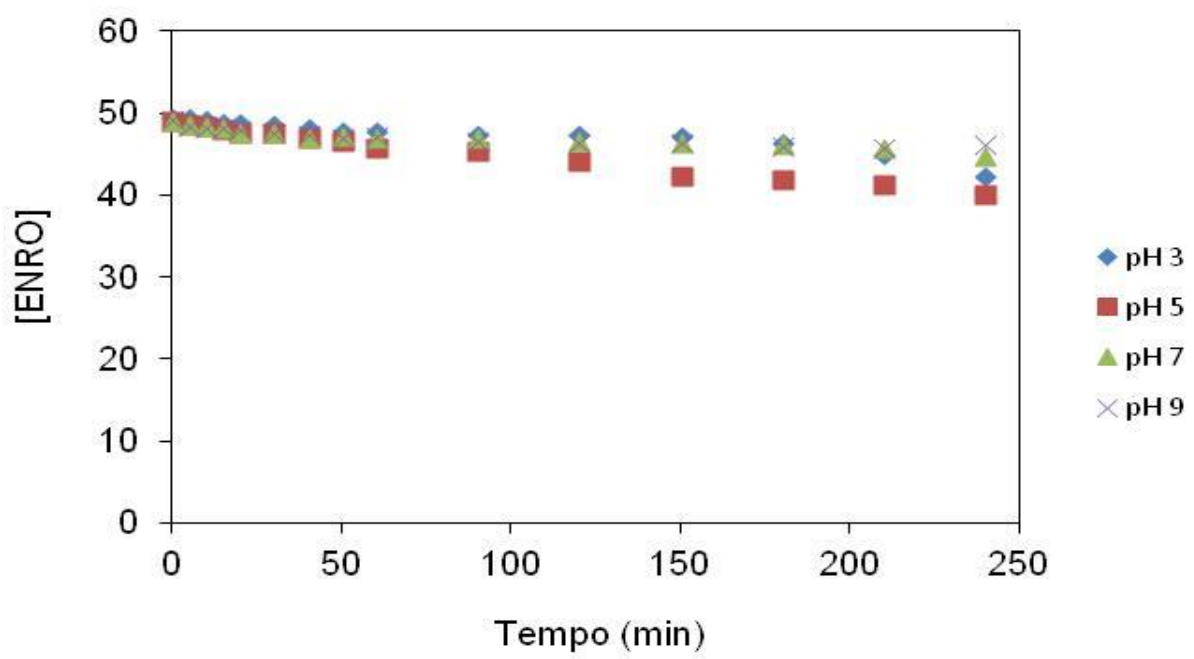

Figura 21 : Resultados dos experimentos de fotólise da ENRO em pH 3, 5, 7 e 9 na presença de BOS B (CVDTFT110). Condições: [ENRO] $]_{0}=50 \mathrm{mg} \mathrm{L}^{-1}$; $\left[\mathrm{BOS} \mathrm{B}_{0}=20 \mathrm{mg} \mathrm{L}^{-1}\right.$; lâmpada de xenônio de $35 \mathrm{~W} ; 25^{\circ} \mathrm{C}$.

Por sua vez, a Figura 22 mostra claramente que a degradação do fármaco foi mais eficiente na presença de BOS C (CVT230) e em pH 7 (87\% de 
remoção). Os resultados sugerem também a existência de um pH ótimo para fotólise na presença de BOS $\mathrm{C}$, já que houve aumento da porcentagem removida do fármaco até $\mathrm{pH} 7$ e diminuição para $\mathrm{pH}$ 9, com $57,6 \%$ de remoção neste último. Como o comportamento de [ENRO] na presença de $\mathrm{BOS} \mathrm{C}$ foi totalmente distinto do observado na presença de BOS A (Figura 20) e B (Figura 21), decidiu-se realizar o conjunto de experimentos 9-12 em triplicata a fim de avaliar sua reprodutibilidade e confirmar esse comportamento.

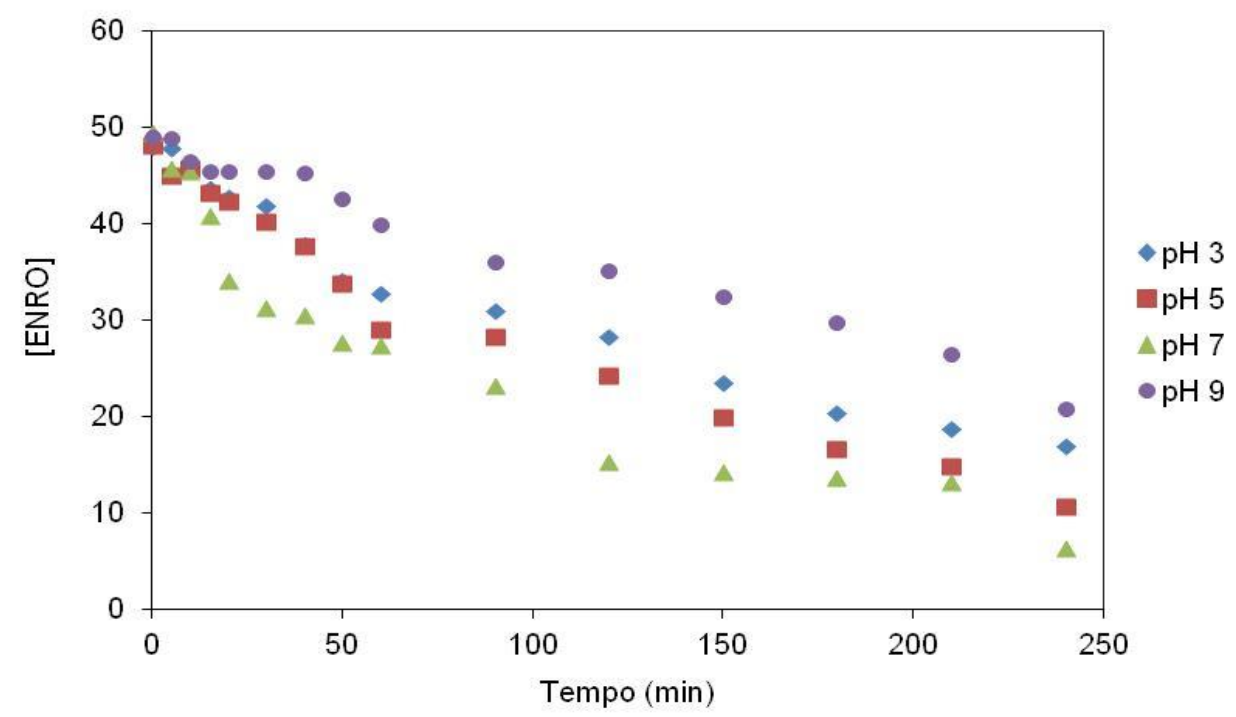

Figura 22 : Resultados dos experimentos de fotólise da ENRO em pH 3, 5, 7 e 9 na presença de BOS C (CVT230). Condições: [ENRO $]_{0}=50 \mathrm{mg} \mathrm{L}^{-1}$; [BOS C] $]_{0}=20 \mathrm{mg} \mathrm{L}^{-1}$; lâmpada de xenônio de $35 \mathrm{~W} ; 25^{\circ} \mathrm{C}$.

A Figura 23 apresenta os resultados, sendo o desvio relativo médio de 5,4\% para os experimentos realizados em $\mathrm{pH} 3 ; 2,4 \%$ para os experimentos realizados em $\mathrm{pH} 5 ; 3,2 \%$ para os experimentos realizados em $\mathrm{pH} 7$ e de $3,1 \%$ para os experimentos realizados em $\mathrm{pH} 9$. 

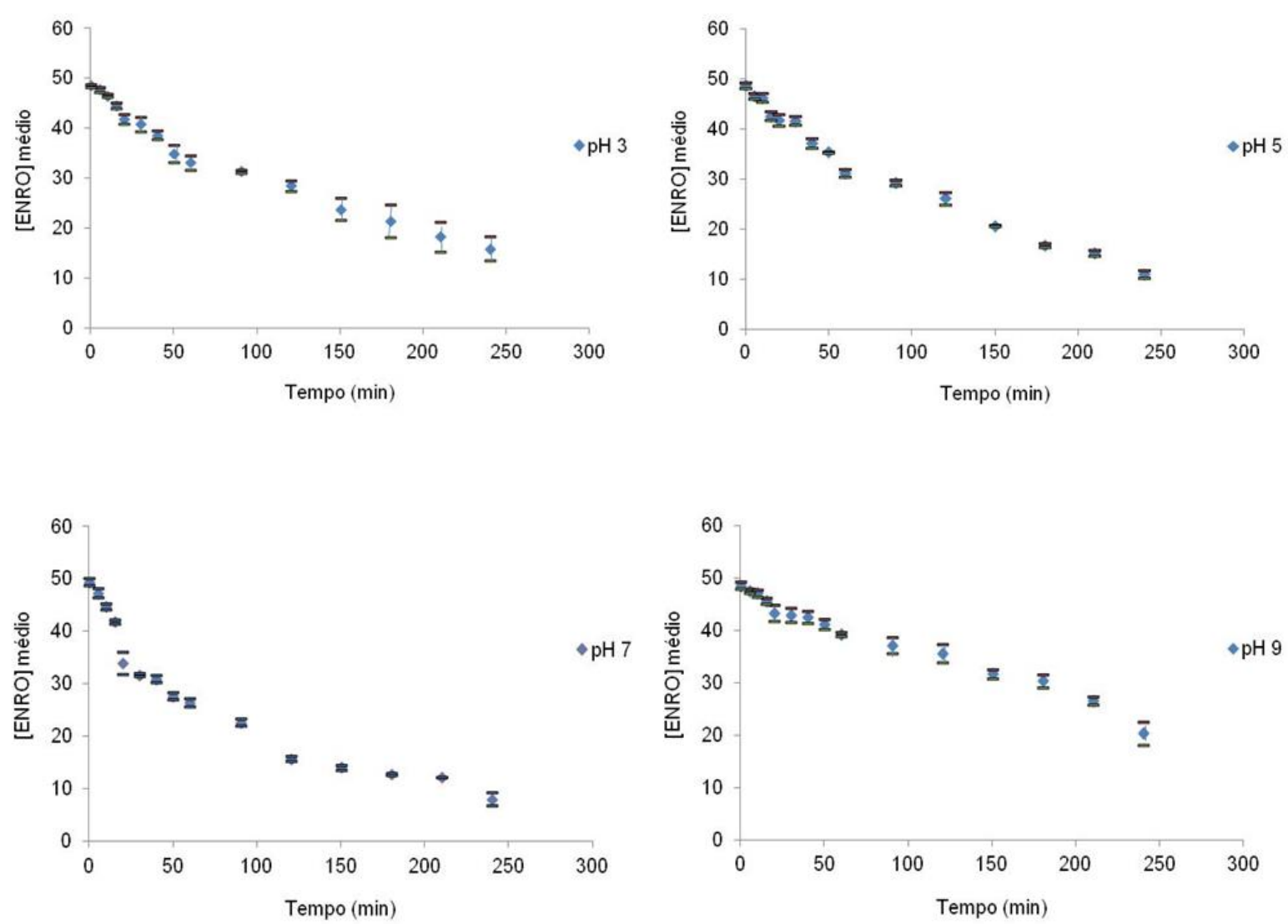

Figura 23 : Resultados dos experimentos de fotólise da ENRO em pH 3, 5, 7 e 9 na presença de BOS C (CVT230) com, com indicação do erro experimental em cada tempo. Condições: $[\mathrm{ENRO}]_{0}=50 \mathrm{mg} \mathrm{L}^{-1}$; [BOS C $]_{0}=20 \mathrm{mg} \mathrm{L}^{-1}$; lâmpada de xenônio de $35 \mathrm{~W} ; 25^{\circ} \mathrm{C}$.

Uma hipótese para os resultados apresentados na Figura 23 são as vias de degradação de poluentes presentes em águas naturais desencadeadas por processos de fotossensitização pela matéria orgânica natural, ou através da fotólise dos compostos presentes na água. Tais processos podem ser particularmente interessantes na presença de luz policromática, considerandose que a maior parte das reações de fotossensitização estudadas ocorre como resultado da irradiação com luz solar simulada e substâncias húmicas (HS) ( $\lambda>300 \mathrm{~nm}$ ), o que pode explicar o comportamento do fármaco na presença de BOS C (CANONICA e FREIBURGHAUS, 2001).

O estado excitado triplete dos compostos orgânicos presentes na água pode induzir a transformação química dos poluentes orgânicos através da transferência de energia direta ou através da geração de espécies reativas que podem reagir com os poluentes. As espécies reativas geradas através dos processos induzidos pela luz em matéria orgânica natural são: o oxigênio singlete molecular $\left({ }^{1} \mathrm{O}_{2}\right)$, radicais peroxil $\left(\mathrm{RO}_{2}^{\circ}\right)$ e hidroperoxil $\left(\mathrm{HO}_{2}^{*}\right)$, ânion- 
radical superóxido $\left(\mathrm{O}^{-}{ }_{2}\right)$, radicais hidroxila $\left({ }^{\circ} \mathrm{OH}\right)$, elétrons hidratados $\left(\mathrm{e}_{\text {aq }}^{-}\right)$e radical carbonato $\left(\mathrm{CO}_{3}^{-}{ }^{-}\right)$. Entre as reações mais freqüentemente encontradas no ambiente aquático envolvendo espécies reativas de curta duração, as que envolvem o radical hidroxila parecem prevalecer. Este radical é em grande parte gerado por meio da fotólise de nitrato, mas pode também ser criado por fotólise de complexos de $\mathrm{Fe}-\mathrm{OH}$ ou $\mathrm{H}_{2} \mathrm{O}_{2}$ (MACK e BOLTON, 1999; ZEPP et al., 1987). MABURY e CROSBY (1994) investigaram a degradação de alguns pesticidas em água irradiada por luz solar simulada $(\lambda>290 \mathrm{~nm})$, atribuíndo seu destino às reações com o radical ${ }^{\circ} \mathrm{OH}$ gerado por substâncias húmicas.

O oxigênio singlete molecular é principalmente gerado como um resultado da desativação do estado triplete de substâncias húmicas pelo estado fundamental do oxigênio dissolvido, conforme a Equação 14:

${ }^{3} \mathrm{HS}^{*}+{ }^{3} \mathrm{O}_{2} \rightarrow \mathrm{HS}+{ }^{1} \mathrm{O}_{2}$

O processo ocorre com rendimento quântico de 0,5-2,6 sob radiação de banda larga (HAAG et al., 1984). Uma vez que a diferença entre os dois níveis energéticos de oxigênio é de apenas $22,7 \mathrm{kcal} \mathrm{mol}^{-1}$, o oxigênio singlete é o principal produto resultante. $O$ oxigênio singlete é um eletrófilo e um receptor de elétrons mais eficiente que o oxigênio triplete. Ele reage com alguns compostos orgânicos reativos que contêm elétrons em duplas ligações, ou são facilmente oxidados, tais como mercaptanas, anilinas e as estruturas fenólicas. Estas estruturas apresentam-se em grande quantidade nos compostos bioorgânicos (BOS).

Os resultados da Figura 22 sugerem que ocorre a fotólise da ENRO promovida por espécies geradas fotoquimicamente a partir da absorção de radiação UV-visível pelo BOS $\mathrm{C}$ na faixa de emissão da lâmpada de xenônio (Figura 8), isto é oxigênio singlete $\left({ }^{1} \mathrm{O}_{2}\right)$ e radicais hidroxila $(\bullet \mathrm{OH})$. A atividade fotoquímica do BOS $\mathrm{C}$ pode estar ligada à presença importante de grupos funcionais aromáticos que promovem absorção na região do vermelho em diante (ENVIRONBOS, 2013), dessa forma, mediram-se os espectros de 
absorção UV-visível do BOS C em solução aquosa, nos diferentes valores de $\mathrm{pH}(3,5,7$ e 9), como mostra a Figura 24.

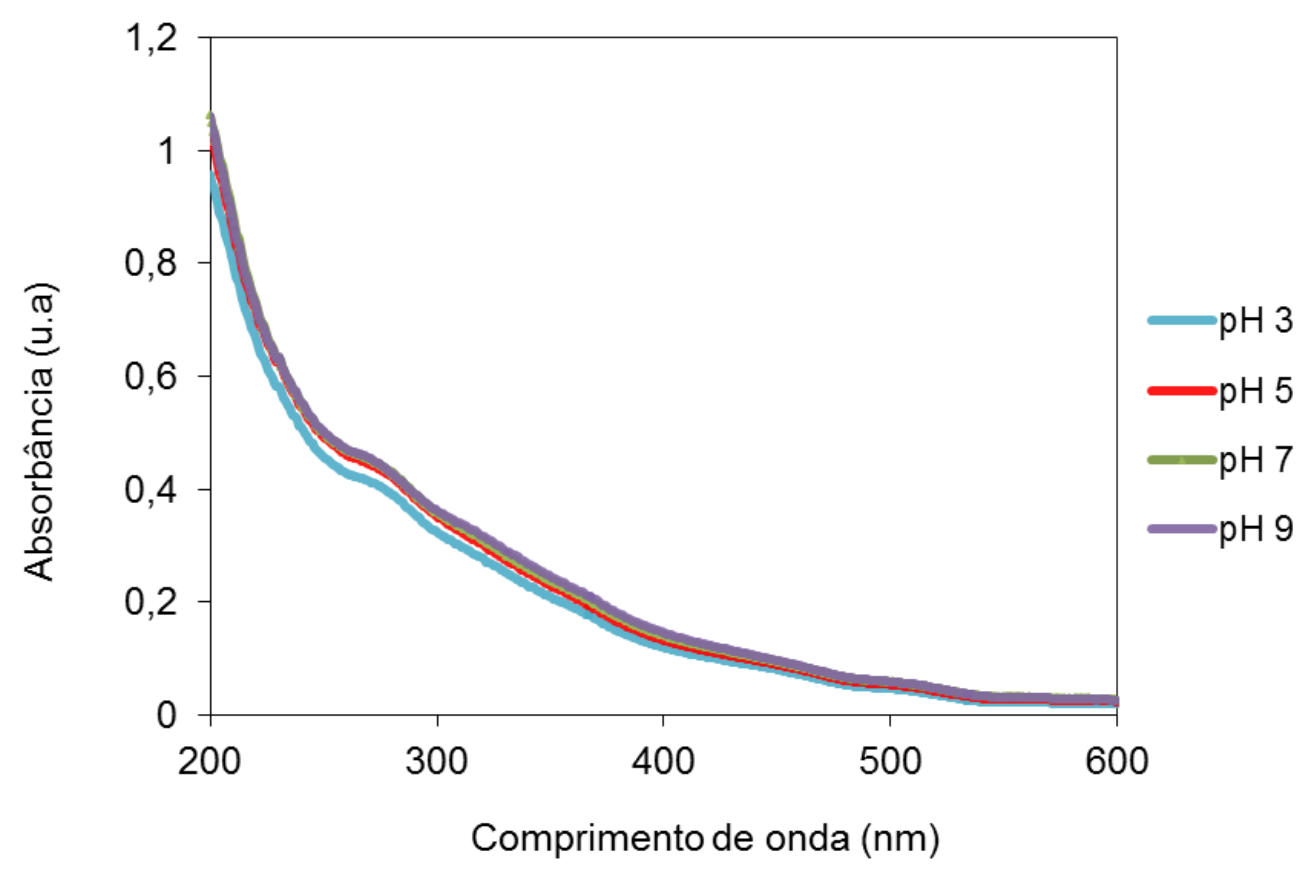

Figura 24 : Absorbância do composto bio-orgânico (BOS C, $20 \mathrm{mg} \mathrm{L}^{-1}$ ) em solução aquosa em diferentes pH (3, 5, 7 e 9). Espectros de absorção medidos com resolução de $1 \mathrm{~nm}$.

A Figura 24 mostra que não há modificação da absorção das soluções aquosas de BOS $\mathrm{C}$ com $0 \mathrm{pH}$. Os espectros de absorção são bem característicos de compostos orgânicos alifáticos e aromáticos (cf. seção 5.4). Por sua vez, a comparação da Figura $25 \mathrm{com}$ a Figura 11 mostra que não há modificação apreciável dos espectros de absorção da enrofloxacina em solução aquosa na presença de BOS $\mathrm{C}$ à concentração empregada, para todos os pH estudados. 


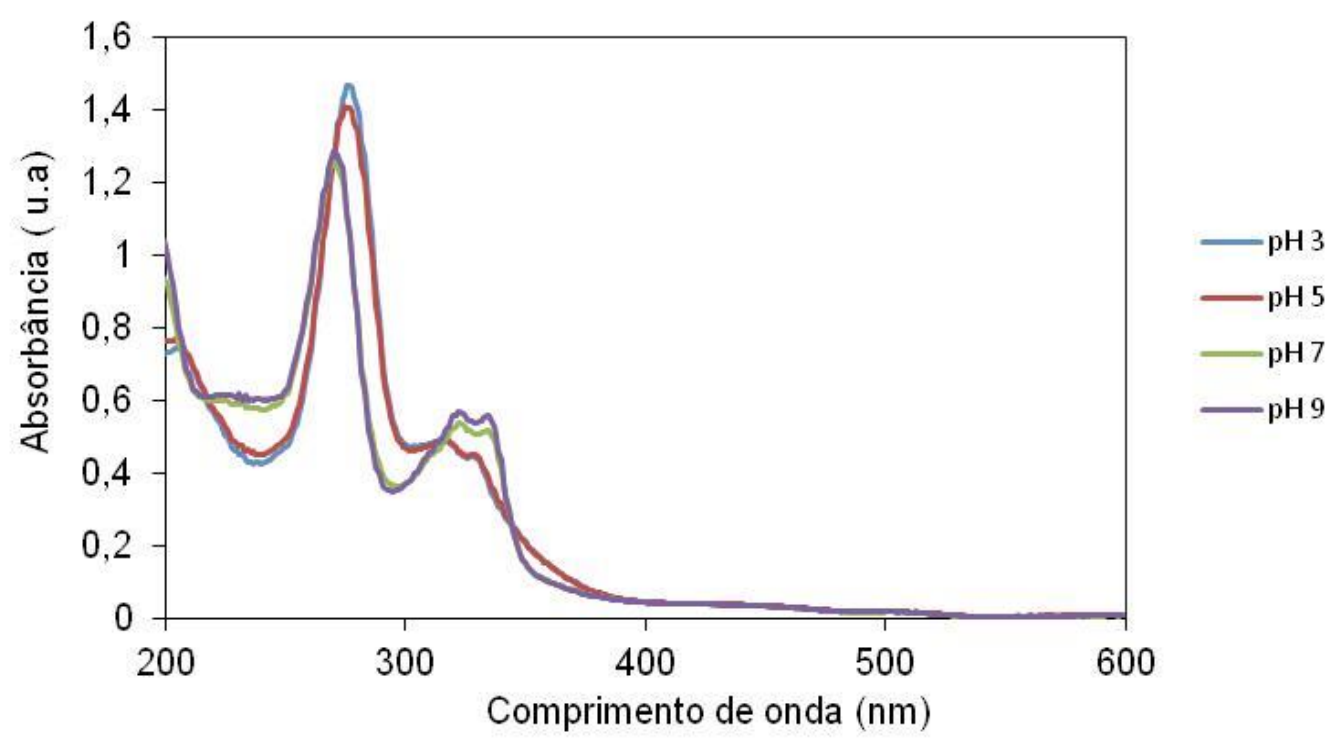

Figura 25 : Absorbância da solução contendo enrofloxacina $\left(5 \mathrm{mg} \mathrm{L}^{-1}\right)$ e BOS C (20 mg $\left.\mathrm{L}^{-1}\right)$ em solução aquosa em diferentes $\mathrm{pH}(3,5,7$ e 9$)$. Espectros de absorção medidos com resolução de $1 \mathrm{~nm}$.

Estudos recentes de degradação de 4-clorofenol (4-CP) na presença de BOS C comprovam o papel do oxigênio singlete $\left({ }^{1} \mathrm{O}_{2}\right)$ e dos radicais hidroxila $(\bullet \mathrm{OH})($ ENVIRONBOS, 2013). Verificou-se que a degradação do 4-CP diminui mais acentuadamente na presença de azida de sódio (consumidor de ${ }^{1} \mathrm{O}_{2}$ ) que na presença de 2-propanol (consumidor de radicais hidroxila); esse efeito é tão mais importante quanto maior a concentração do BOS. De fato, estudos de ressonância paramagnética eletrônica (EPR) confirmaram que a geração de oxigênio singlete a partir da irradiação do BOS $\mathrm{C}$ aumenta linearmente com a concentração do BOS, ao passo que a geração de radicais hidroxila aumenta com o aumento da concentração de BOS, passando por um máximo e diminuindo em seguida. Este comportamento pode ser explicado pela ocorrência de dois efeitos concorrentes: geração e consumo de radicais $\cdot \mathrm{OH}$ pelo próprio BOS C (ENVIRONBOS, 2013).

A hipótese de participação do oxigênio singlete como espécie oxidante principal, gerada a partir da foto-excitação do BOS C, foi verificada a partir de um experimento realizado em meio anóxico, borbulhando-se argônio grau técnico na solução contida no tanque de mistura. O resultado é apresentado na Figura 26. 


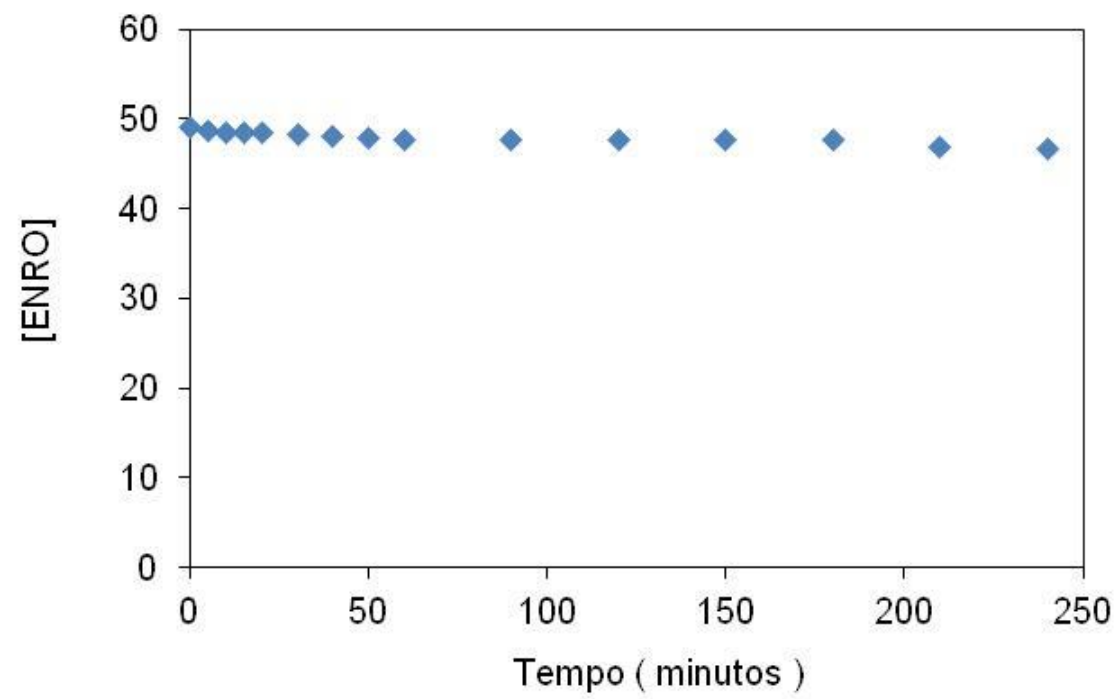

Figura 26 : Experimento realizado em meio anóxico em $\mathrm{pH} 7$ a $25^{\circ} \mathrm{C}$. Condições: $[E N R O]_{0}=50 \mathrm{mg} \mathrm{L}^{-1}$, $[\mathrm{BOS}]_{0}=20 \mathrm{mg} \mathrm{L}^{-1}$; lâmpada de xenônio de $35 \mathrm{~W}$.

Observa-se que a concentração de enrofloxacina permaneceu constante, o que permite dizer que é necessária a presença de oxigênio dissolvido para que haja degradação da ENRO. Ao se inserir argônio durante o experimento, são inibidas as reações dependentes de oxigênio, como as dadas pelas Equações 15 e 16, correspondentes à transferência de elétron com formação do ânionradical superóxido e à formação do oxigênio singlete a partir da transferência de energia entre o estado excitado de substâncias húmicas presentes no BOS $\left(H S^{\star}\right)$ e o oxigênio triplete dissolvido, respectivamente.

$$
\begin{aligned}
& \mathrm{HS}^{*}+\mathrm{O}_{2} \rightarrow \mathrm{HS}^{+\cdot}+\mathrm{O}_{2}^{-\cdot} \\
& \mathrm{HS}^{*}+{ }^{3} \mathrm{O}_{2} \rightarrow \mathrm{HS}+{ }^{1} \mathrm{O}_{2}
\end{aligned}
$$

5.6 Estudo da Degradação da Enrofloxacina pelo Processo $\mathrm{H}_{2} \mathrm{O}_{2} / \mathrm{UV}$

Apresentam-se a seguir resultados de experimentos de degradação da enrofloxacina (ENRO) por meio do processo $\mathrm{H}_{2} \mathrm{O}_{2} / \mathrm{UV}$, para concentração inicial nominal de $50 \mathrm{mg} \mathrm{L}^{-1}$ de ENRO e $4,2 \mathrm{mg} \mathrm{L}^{-1}$ de $\mathrm{H}_{2} \mathrm{O}_{2}$. Fo utilizada a 
lâmpada de xenônio de $35 \mathrm{~W}$. A Tabela 9 indica que em todos os experimentos obteve-se degradação da ENRO. No primeiro experimento, irradiou-se a solução aquosa contendo somente ENRO e $\mathrm{H}_{2} \mathrm{O}_{2}$; no segundo, irradiou-se a solução contendo ENRO, $\mathrm{H}_{2} \mathrm{O}_{2}$ e BOS C. Assim como no caso dos experimentos de fotólise, a solução aquosa adquiriu coloração castanha, mantendo-se límpida, quando adicionado o BOS. Todas as repetições dos experimentos mostraram-se adequadas, à exceção do experimento 1 (Figura 27 a Figura 30$)$.

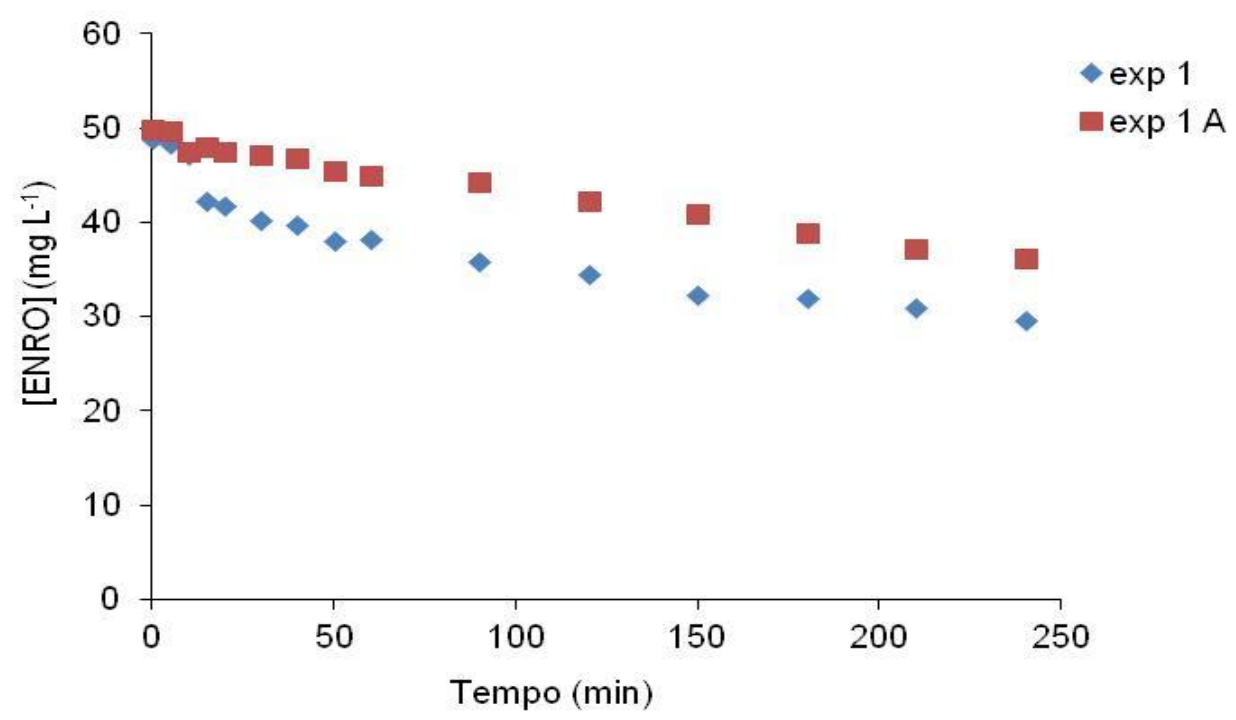

Figura 27 : Comparação entre o tratamento da solução aquosa contendo ENRO em pH 3 identificados com 1 e $1 \mathrm{~A}$ a $25^{\circ} \mathrm{C}$. Condições: [ENRO $]_{0}=50 \mathrm{mg} \mathrm{L}^{-1},\left[\mathrm{H}_{2} \mathrm{O}_{2}\right]_{0}=4,2 \mathrm{mg} \mathrm{L}^{-1}$, lâmpada de xenônio de $35 \mathrm{~W}$. 


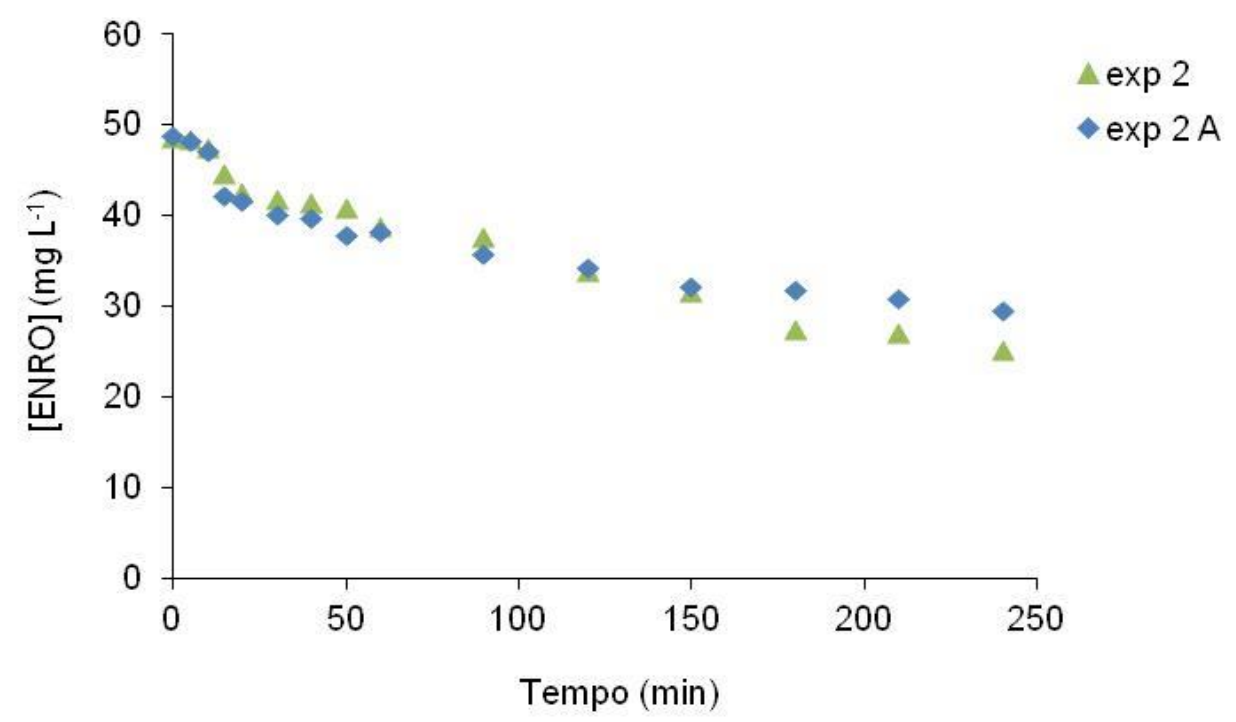

Figura 28 : Comparação entre o tratamento da solução aquosa contendo ENRO em pH 7 identificados com 2 e $2 \mathrm{~A}$ a $25^{\circ} \mathrm{C}$. Condições: [ENRO ] $]_{0}=50 \mathrm{mg} \mathrm{L}^{-1},\left[\mathrm{H}_{2} \mathrm{O}_{2}\right]_{0}=4,2 \mathrm{mg} \mathrm{L}^{-1}$, lâmpada de xenônio de $35 \mathrm{~W}$.

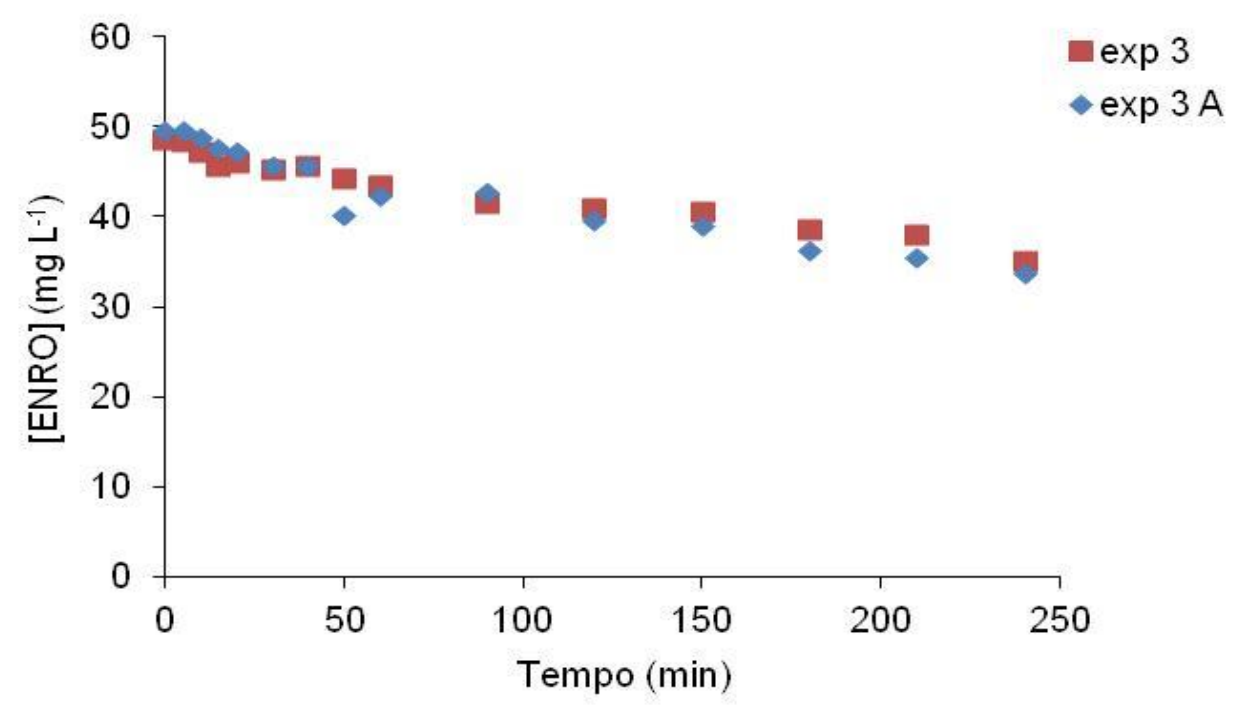

Figura 29 : Comparação entre o tratamento da solução aquosa contendo ENRO em pH 3 identificados 3 e $3 \mathrm{~A}$ a $25^{\circ} \mathrm{C}$. Condições: $[\mathrm{ENRO}]_{0}=50 \mathrm{mg} \mathrm{L}^{-1}$, $\left[\mathrm{H}_{2} \mathrm{O}_{2}\right]_{0}=4,2 \mathrm{mg} \mathrm{L}^{-1}$, [BOS $]_{0}=20$ $\mathrm{mg} \mathrm{L}^{-1}$; lâmpada de xenônio de $35 \mathrm{~W}$. 


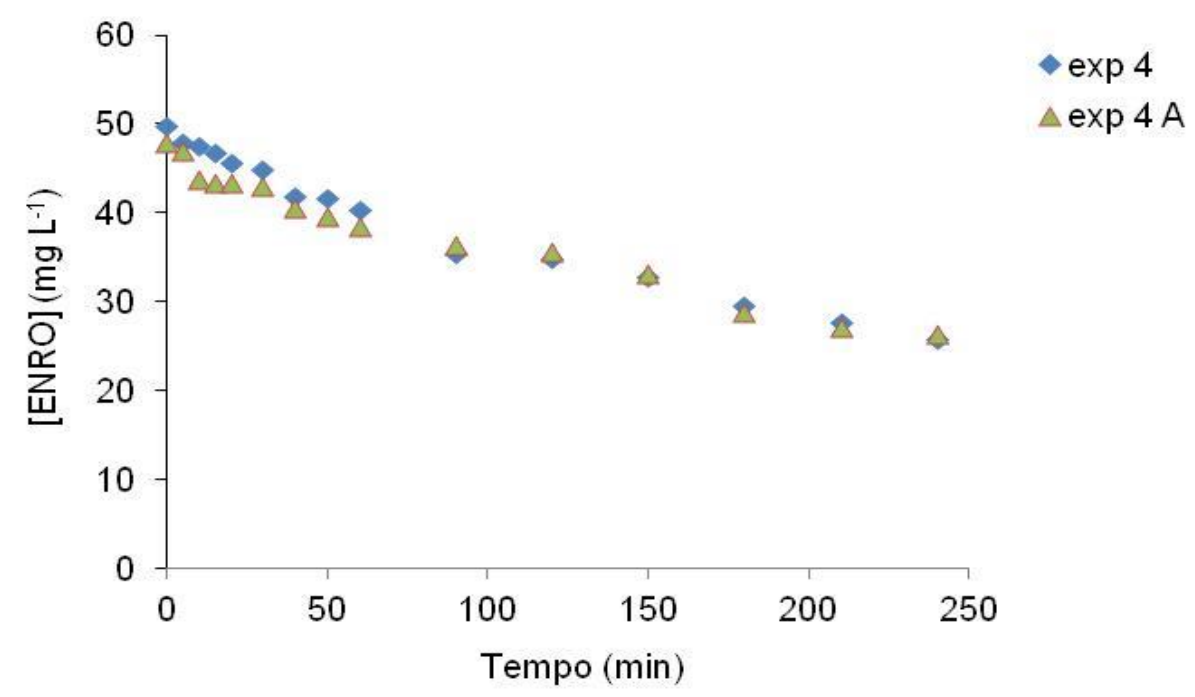

Figura 30 : Comparação entre o tratamento da solução aquosa contendo ENRO em pH 7 identificados 4 e $4 \mathrm{~A}$ a $25^{\circ} \mathrm{C}$. Condições: $[\mathrm{ENRO}]_{0}=50 \mathrm{mg} \mathrm{L}^{-1},\left[\mathrm{H}_{2} \mathrm{O}_{2}\right]_{0}=4,2 \mathrm{mg} \mathrm{L}^{-1},[\mathrm{BOS}]_{0}=20$ $\mathrm{mg} \mathrm{L}^{-1}$; lâmpada de xenônio de $35 \mathrm{~W}$.

Tabela 9: Resultados dos experimentos de degradação da enrofloxacina pelo processo $\mathrm{UV} / \mathrm{H}_{2} \mathrm{O}_{2}$

\begin{tabular}{|c|c|c|c|c|c|}
\hline Exp & BOS & $\begin{array}{l}\text { [ENRO] } \\
\left(\mathrm{mg} \mathrm{L}^{-1}\right)\end{array}$ & $\mathrm{pH}^{(\mathrm{a})}$ & $\begin{array}{c}\text { Remoção } \\
\text { ENRO(c) }(\%) \\
(\%)\end{array}$ & $\begin{array}{c}\text { Tempo } \\
\text { (min) para remoção } \\
\text { de } 50 \% \text { da } \\
\text { concentração inicial }\end{array}$ \\
\hline 1 & - & 48,83 & 3 & 39,0 & $\bar{N}$ \\
\hline $1^{a}$ & - & 49,50 & 3 & 27,0 & $\mathrm{~N}$ \\
\hline 2 & - & 48,30 & 7 & 48,0 & 240 \\
\hline $2^{\mathrm{a}}$ & - & 48,50 & 7 & 39,0 & 240 \\
\hline 3 & & 48,76 & 3 & 28,0 & $\mathrm{~N}$ \\
\hline $3^{a}$ & C & 49,30 & 3 & 32,0 & $\mathrm{~N}$ \\
\hline 4 & & 49,84 & 7 & 48,0 & 240 \\
\hline $4^{a}$ & & 48,03 & 7 & 44,0 & 240 \\
\hline
\end{tabular}

Os resultados indicam que a degradação da ENRO pelo processo $\mathrm{UV} / \mathrm{H}_{2} \mathrm{O}_{2}$ na ausência de BOS mostrou-se mais eficiente em pH 7 que em pH 3 (Tabela 9 e Figura 30Figura 35). Nesse caso, obtiveram-se remoções médias ao final de 240 minutos iguais a $44 \%$ e $33 \%$, respectivamente. Deve-se lembrar da contribuição da fotólise da enrofloxacina nesses experimentos (Figura 18), 
pouco importante em $\mathrm{pH} 3$, porém atingindo cerca de $20 \%$ para $\mathrm{pH} 7$. Nesse $\mathrm{pH}$, a Figura 13 indica que o coeficiente de absorção molar da ENRO é alto no intervalo de comprimentos de onda 254-300 nm $\left(\varepsilon\right.$ entre 10000-15000 $\mathrm{L} \mathrm{mol}^{-1}$ $\mathrm{cm}^{-1}$, com máximo de ca. $42000 \mathrm{~L} \mathrm{~mol}^{-1} \mathrm{~cm}^{-1}$ em $275 \mathrm{~nm}$ ) e no intervalo 300 $400 \mathrm{~nm}\left(18000-25000 \mathrm{~L} \mathrm{~mol}^{-1} \mathrm{~cm}^{-1}\right.$ em $\left.330 \mathrm{~nm}\right)$.

Por outro lado, o coeficiente de absorção molar do $\mathrm{H}_{2} \mathrm{O}_{2}$ é muito baixo nesse mesmo intervalo, valendo ca. $20 \mathrm{~L} \mathrm{~mol}^{-1} \mathrm{~cm}^{-1}$ em $254 \mathrm{~nm}$ e aproximandose de zero em 300 nm (OPPENLÄNDER, 2003), de modo que não se espera fotólise substancial desse oxidante; a emissão da lâmpada também é pouco importante nesse intervalo (Figura 8). Também se deve considerar a estabilidade da molécula de $\mathrm{H}_{2} \mathrm{O}_{2}$ em $\mathrm{pH} 7 \quad\left(\mathrm{pK}_{\mathrm{a}}=11,5\right.$, conforme CHEMICALIZE, 2013), sendo desprezível a concentração de sua base conjugada $\mathrm{HO}_{2}^{-}\left(\varepsilon=240 \mathrm{~L} \mathrm{~mol}^{-1} \mathrm{~cm}^{-1}\right.$ em $254 \mathrm{~nm}$, conforme OPPENLÄNDER, 2003). Dessa forma, o fato de ter-se obtido remoção de ENRO próxima a 50\% no sistema $\mathrm{H}_{2} \mathrm{O}_{2} / \mathrm{UV}$ deve ser explicado por outro mecanismo que não principalmente $o$ ataque de radicais hidroxila gerados a partir do peróxido de hidrogênio.

Quando adicionado o BOS C (20 $\left.\mathrm{mg} \mathrm{L}^{-1}\right)$ à solução de enrofloxacina, observou-se que em pH 3 o porcentual médio de remoção foi de $30 \%$, sendo da mesma ordem da remoção obtida na ausência de BOS C (Tabela 9). A maior degradação de ENRO foi identificada em $\mathrm{pH} 7$, independentemente da presença de BOS C, sendo removidos em média $46 \%$ do fármaco em relação à concentração inicial no período de 240 minutos. Dessa forma, a menos do resultado obtido para o experimento 1, os resultados da Tabela 9 e as Figura 31 e 32 sugerem que no processo $\mathrm{H}_{2} \mathrm{O}_{2} / \mathrm{UV}$ a adição do $\mathrm{BOS} \mathrm{C}$ não influenciou a degradação do fármaco. Na presença de baixas concentrações de BOS e/ou baixa potência radiante, isso pode ser resultado do consumo de radicais hidroxila, gerados a partir da irradiação do BOS, pelas moléculas de $\mathrm{H}_{2} \mathrm{O}_{2}$ e pelo próprio $\mathrm{BOS}$, além do ataque à enrofloxacina. Finalmente, mesmo tendo sido identificada em estudos recentes a presença de ferro (ca. $0,8 \% \mathrm{~m} / \mathrm{m})$ no BOS C (ENVIRONBOS, 2013), para a concentração de BOS empregada neste trabalho aparentemente não houve contribuição da reação de Fenton $\left(\mathrm{H}_{2} \mathrm{O}_{2}+\mathrm{Fe}^{2+}\right.$ ou $\left.\mathrm{H}_{2} \mathrm{O}_{2} / \mathrm{Fe}^{3+}\right)$ para a degração da enrofloxacina. 


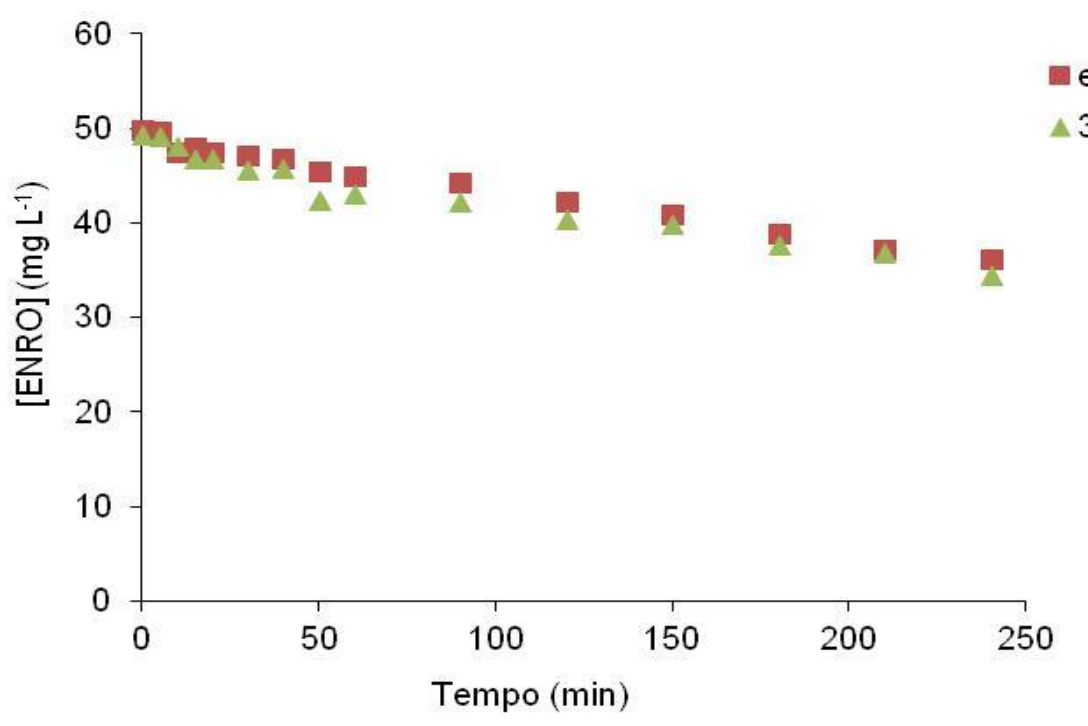

Figura 31 : Comparação entre os resultados dos experimentos $1 \mathrm{~A}$ e 3 (valores médios) realizados em pH 3 a $25^{\circ} \mathrm{C}$. Condições: $[E N R O]_{0}=50 \mathrm{mg} \mathrm{L}^{-1},\left[\mathrm{H}_{2} \mathrm{O}_{2}\right]_{0}=4,2 \mathrm{mg} \mathrm{L}^{-1},[B O S]_{0}=20$ $\mathrm{mg} \mathrm{L}^{-1}$; lâmpada de xenônio de $35 \mathrm{~W}$.

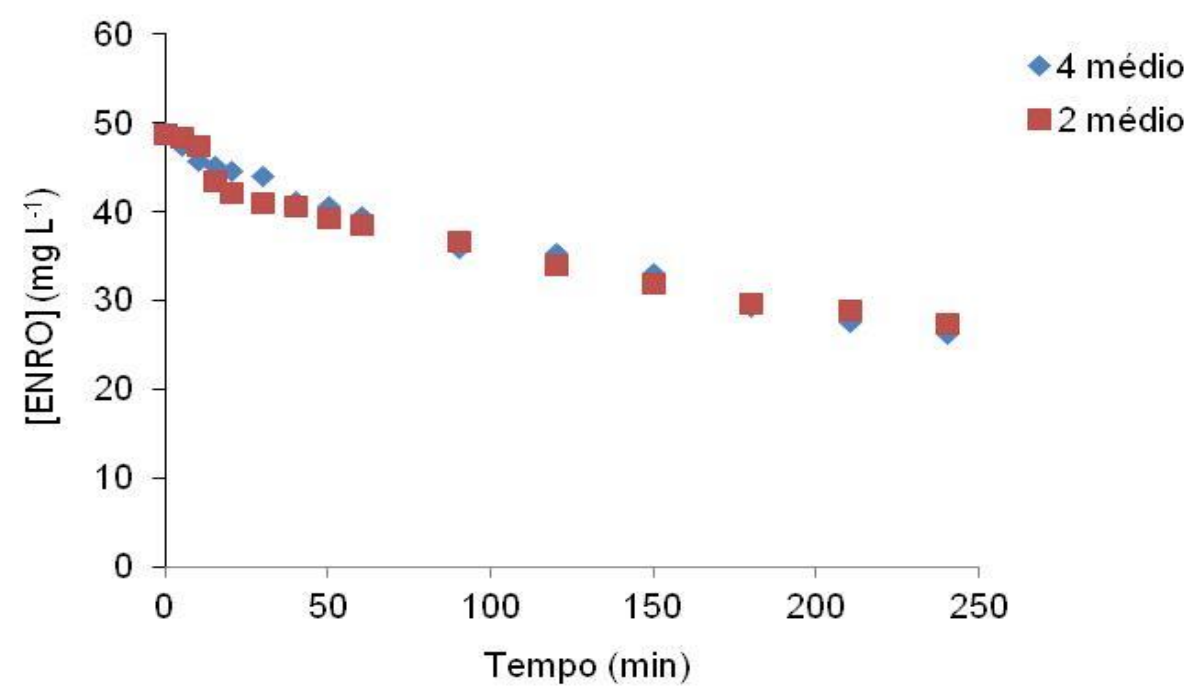

Figura 32 : Comparação entre os resultados dos experimentos 2 e 4 (valores médios) realizados em pH 7 a $25^{\circ} \mathrm{C}$. Condições: $[E N R O]_{0}=50 \mathrm{mg} \mathrm{L}^{-1},\left[\mathrm{H}_{2} \mathrm{O}_{2}\right]_{0}=4,2 \mathrm{mg} \mathrm{L}^{-1},[\mathrm{BOS}]_{0}=20$ $\mathrm{mg} \mathrm{L}^{-1}$; lâmpada de xenônio de $35 \mathrm{~W}$.

Finalmente, apresentam-se nas Figura 33 e 34 resultados de experimentos de degradação da enrofloxacina na presença de $\mathrm{H}_{2} \mathrm{O}_{2}$, porém na ausência de irradiação, para concentração inicial nominal de $50 \mathrm{mg} \mathrm{L}^{-1}$ de ENRO e 4,2 mg $\mathrm{L}^{-1}$ de $\mathrm{H}_{2} \mathrm{O}_{2}$ e $20 \mathrm{mg} \mathrm{L}^{-1}$ de BOS $\mathrm{C}$ realizados nos $\mathrm{pH} 3$ e 7 . Observa-se que a concentração do fármaco permaneceu praticamente constante, com pequena remoção de [ENRO], cerca de 10\%, em até 25 minutos, o que confirma a 
necessidade da radiação para ocorrência de degradação do antibiótico. Espera-se resultado similar para experimentos realizados em $\mathrm{pH} 3$ e 7, na presença de $\mathrm{H}_{2} \mathrm{O}_{2}$, porém na ausência de irradiação e de BOS, o que sugere que a degradação da enrofloxacina por oxidação direta por peróxido de hidrogênio é pouco importante ou desprezível nas condições estudadas.

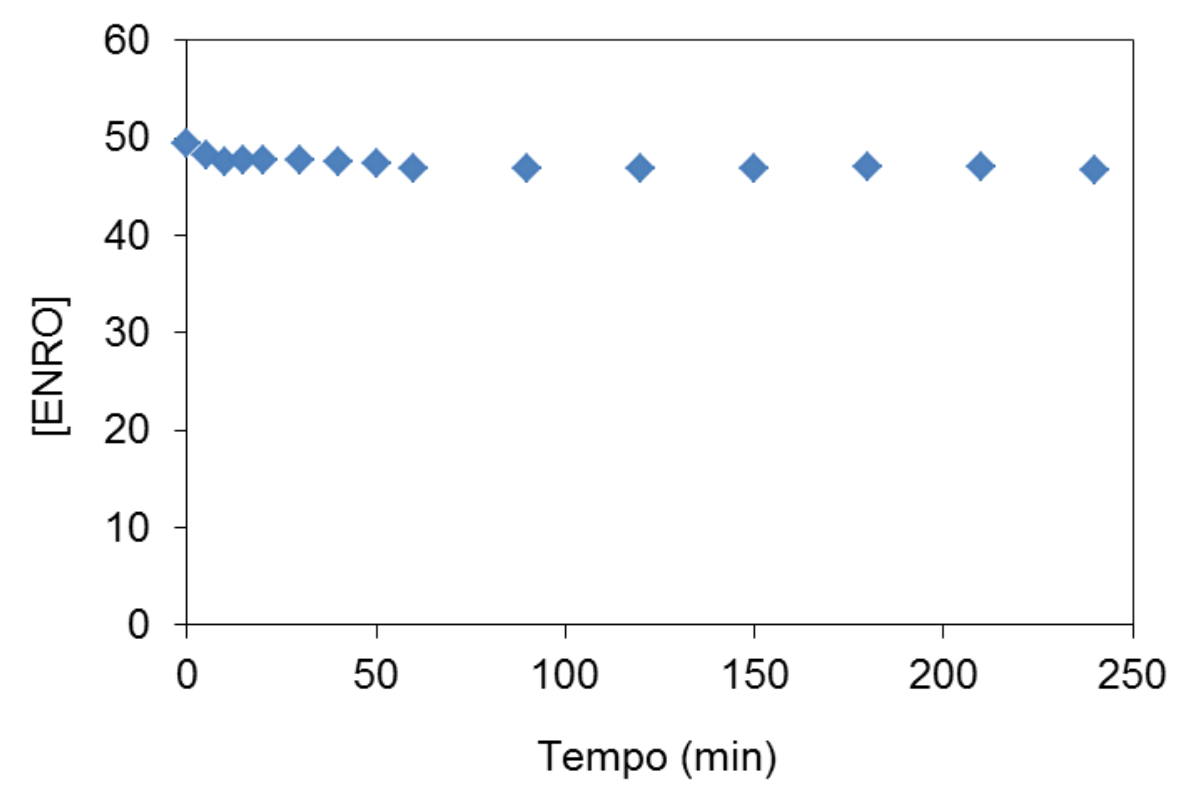

Figura 33 : Experimento realizado na presença de $\mathrm{H}_{2} \mathrm{O}_{2}$ sem radiação da solução aquosa contendo ENRO em pH 3 a $25^{\circ} \mathrm{C}$. Condições: [ENRO $]_{0}=50 \mathrm{mg} \mathrm{L}^{-1},\left[\mathrm{H}_{2} \mathrm{O}_{2}\right]_{0}=4,2 \mathrm{mg} \mathrm{L}^{-1}$, $[\mathrm{BOS}]_{0}=20 \mathrm{mg} \mathrm{L}^{-1}$.

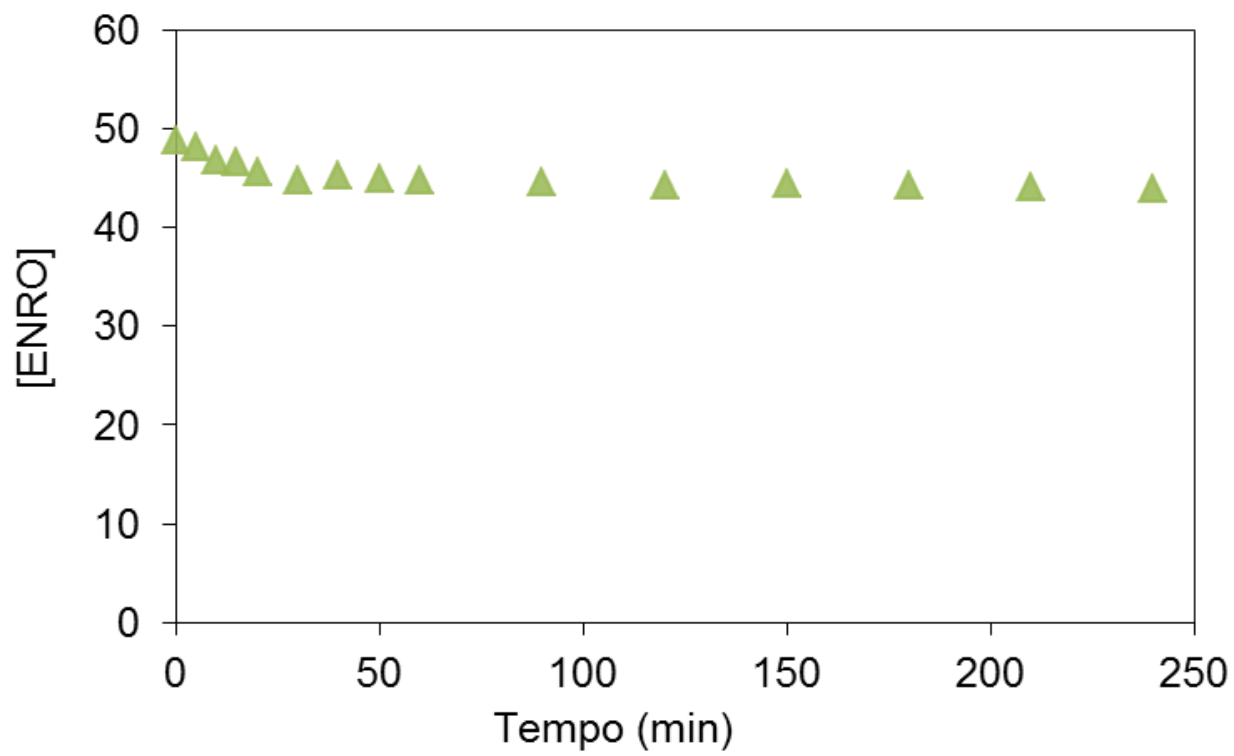

Figura 34 : Experimento realizado na presença de $\mathrm{H}_{2} \mathrm{O}_{2}$ sem radiação da solução aquosa contendo ENRO em pH 7 a $25^{\circ} \mathrm{C}$. Condições: [ENRO $]_{0}=50 \mathrm{mg} \mathrm{L}^{-1},\left[\mathrm{H}_{2} \mathrm{O}_{2}\right]_{0}=4,2 \mathrm{mg} \mathrm{L}^{-1}$, $[\mathrm{BOS}]_{0}=20 \mathrm{mg} \mathrm{L}^{-1}$. 
As Figura 35 e 36 comparam os resultados para os diferentes sistemas estudados no estudo da degradação de enrofloxacina em solução aquosa (fotólise, fotólise na presença de BOS C-CVT230, $\mathrm{H}_{2} \mathrm{O}_{2} / \mathrm{UV}$ e $\mathrm{H}_{2} \mathrm{O}_{2} / \mathrm{UV}$ na presença de BOS C-CVT230) em pH 3 e 7, respectivamente. As remoções obtidas ao final de 240 minutos são comparadas nas Figuras 37 e 38.

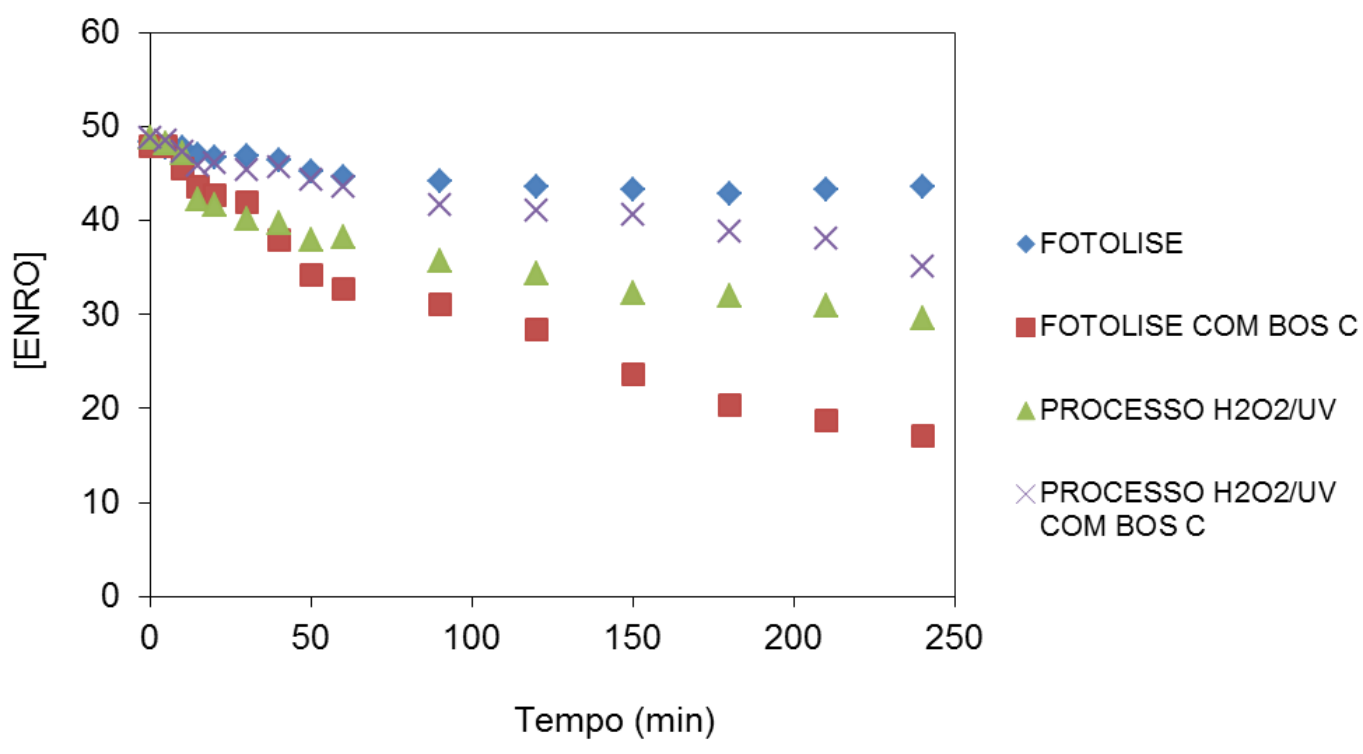

Figura 35 : Comparação entre os diferentes processos de tratamento da solução aquosa contendo ENRO em pH 3 a $25^{\circ} \mathrm{C}$. Condições: [ENRO $]_{0}=50 \mathrm{mg} \mathrm{L}^{-1},\left[\mathrm{H}_{2} \mathrm{O}_{2}\right]_{0}=4,2 \mathrm{mg} \mathrm{L}^{-1}$, $[\mathrm{BOS}]_{0}=20 \mathrm{mg} \mathrm{L}^{-1}$; lâmpada de xenônio de $35 \mathrm{~W}$.

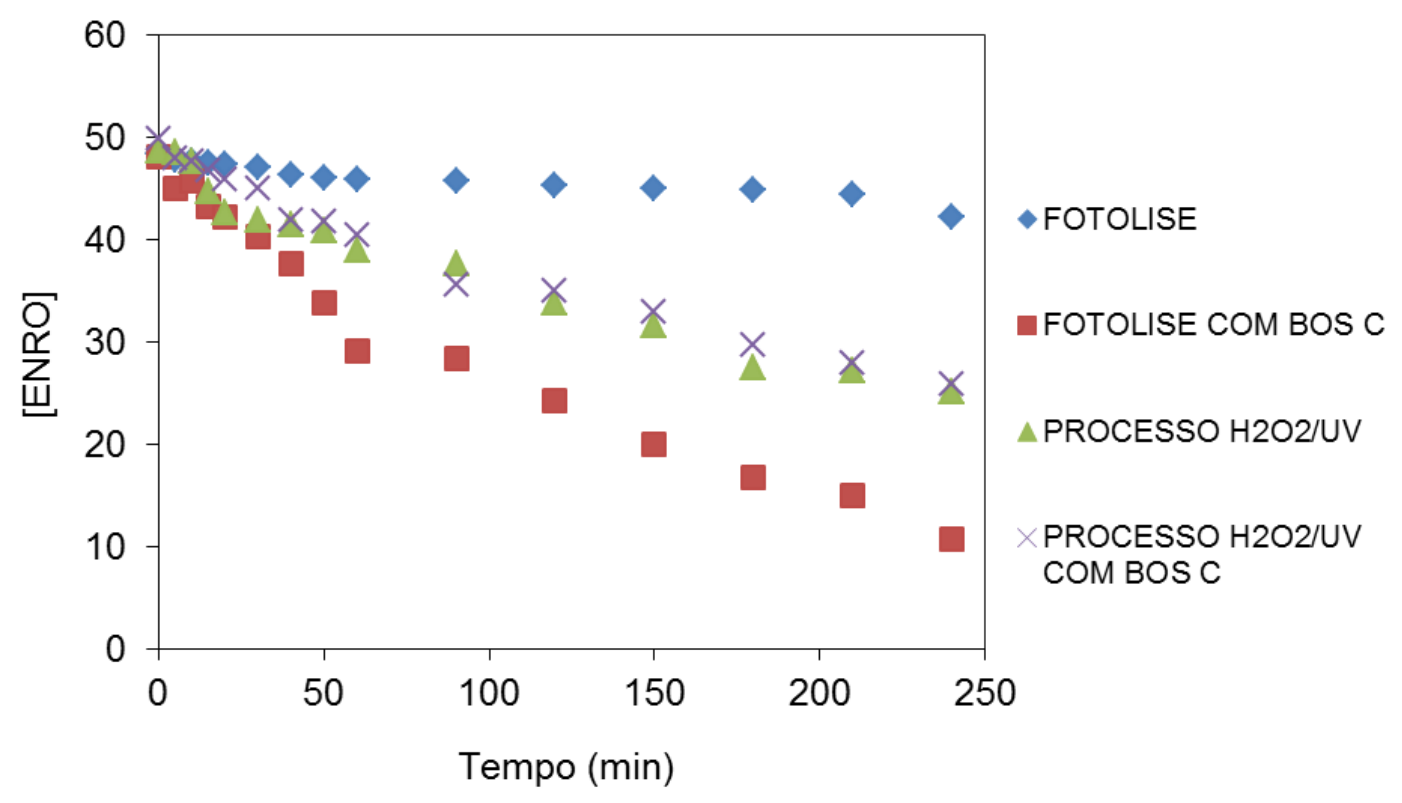

Figura 36 : Comparação entre os diferentes processos de tratamento da solução aquosa contendo ENRO em pH 7 a $25^{\circ} \mathrm{C}$. Condições: [ENRO $]_{0}=50 \mathrm{mg} \mathrm{L}^{-1},\left[\mathrm{H}_{2} \mathrm{O}_{2}\right]_{0}=4,2 \mathrm{mg} \mathrm{L}^{-1}$, $[B O S]_{0}=20 \mathrm{mg} \mathrm{L}^{-1}$; lâmpada de xenônio de $35 \mathrm{~W}$. 


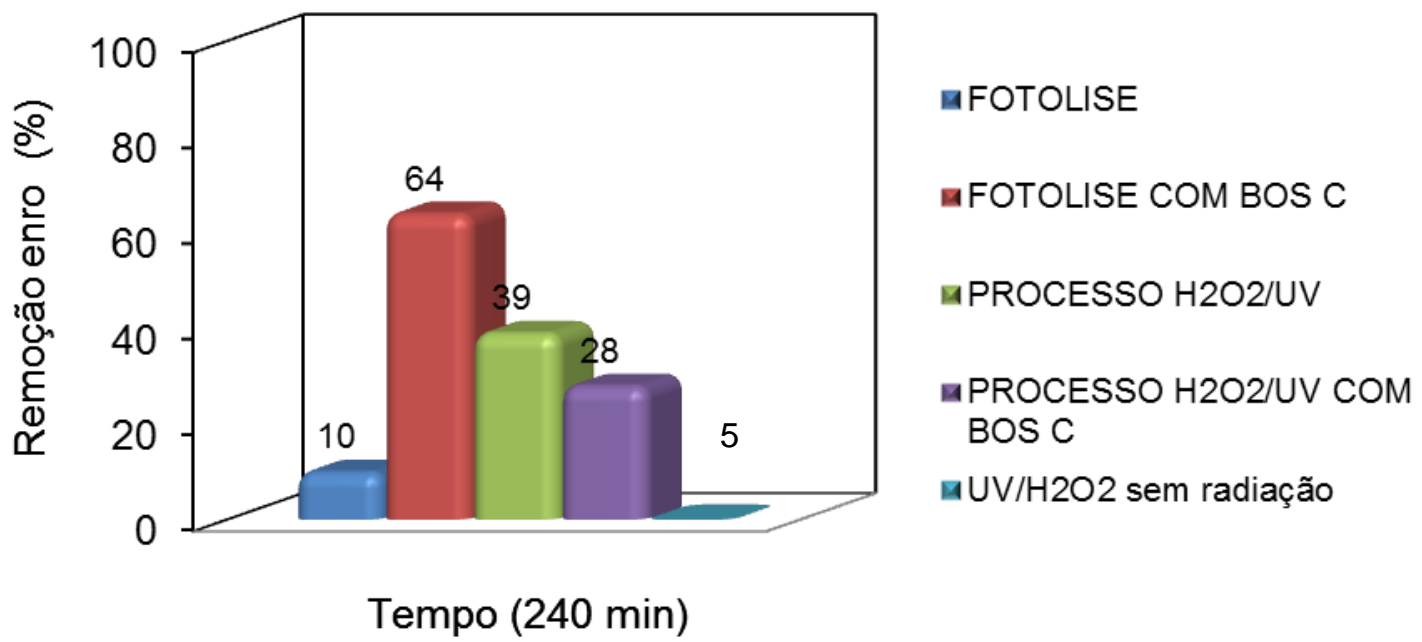

Figura 37 : Comparação entre as remoções de enrofloxacina obtidas ao final de 240 minutos para os diferentes processos de tratamento em pH 3 a $25^{\circ} \mathrm{C}$. Condições: [ENRO] $]_{0}=50$ $\mathrm{mg} \mathrm{L}^{-1},\left[\mathrm{H}_{2} \mathrm{O}_{2}\right]_{0}=4,2 \mathrm{mg} \mathrm{L}^{-1}$, [BOS $]_{0}=20 \mathrm{mg} \mathrm{L}^{-1}$; lâmpada de xenônio de $35 \mathrm{~W}$.

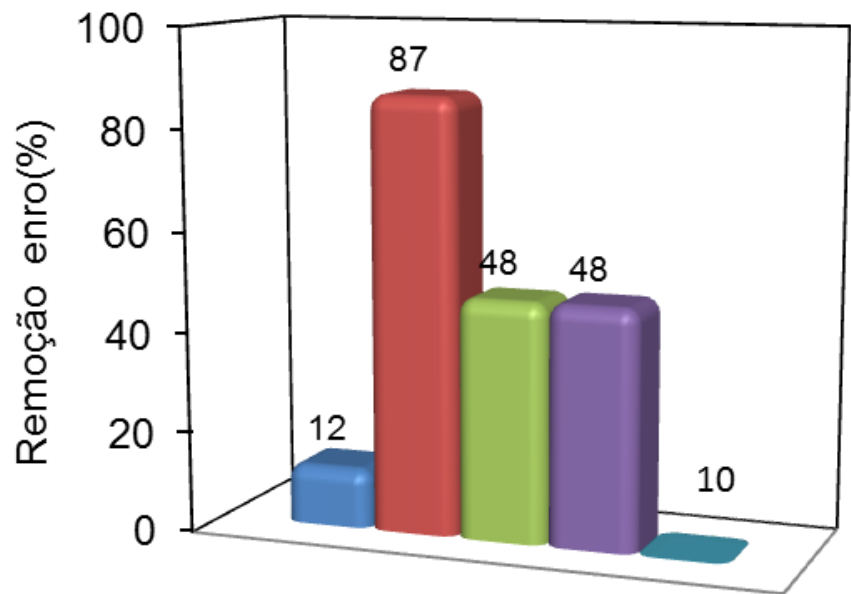

\author{
aFOTOLISE \\ -FOTOLISE COM BOS C \\ aPROCESSO H2O2/UV \\ a PROCESSO H2O2/UV \\ COM BOS C \\ घUV/H2O2 sem radiação
}

Tempo (240 min)

Figura 38 : Comparação entre as remoções de enrofloxacina obtidas ao final de 240 minutos para os diferentes processos de tratamento em pH 7 a $25^{\circ} \mathrm{C}$. Condições: [ENRO] $]_{0}=50$ $\mathrm{mg} \mathrm{L}^{-1},\left[\mathrm{H}_{2} \mathrm{O}_{2}\right]_{0}=4,2 \mathrm{mg} \mathrm{L}^{-1}$, [BOS $]_{0}=20 \mathrm{mg} \mathrm{L}^{-1}$; lâmpada de xenônio de $35 \mathrm{~W}$.

Como já mencionado, o tratamento por fotólise na presença de BOS C foi o processo mais eficiente para a degradação do fármaco presente na solução, com quase $90 \%$ de remoção. 


\section{CONCLUSÕES}

O presente trabalho contribui para o estudo da degradação do antibiótico enrofloxacina (ENRO) em solução aquosa na presença de compostos bioorgânicos (BOS) obtidos a partir de resíduos sólidos urbanos.

A enrofloxacina apresenta como importante característica máxima absorção de radiação UV entre 275 e $335 \mathrm{~nm}$, com importante dependência do coeficiente de absorção molar em função do pH (aproximadamente $40 \%$ se comparados em pH 3 e 9) e importante absorção na faixa de emissão da lâmpada de xenônio (300-800 nm), com $\varepsilon=18000-25000 \mathrm{~L} \mathrm{~mol}^{-1} \mathrm{~cm}^{-1}$ em 330 $\mathrm{nm}$. O fármaco apresenta estabilidade química em meios ácido, neutro e básico, como observado a partir dos ensaios de hidrólise de 24 horas.

Os compostos bio-orgânicos estudados neste trabalho mostraram importante ação como tensoativos, o que dependente do efeito de sua composição sobre o balanço lipofílico-hidrofílico.

Os resultados apresentados indicam que a fotólise da enrofloxacina é um processo eficiente somente na presença de compostos bio-orgânicos (BOS). No entanto, os compostos bio-orgânicos $A$ (FORSUD) e B (CVDFT110) não apresentaram resultados satisfatórios, sendo o máximo de remoção de ENRO de apenas $18 \%$. Por outro lado, os experimentos realizados com BOS C (CVT 230) indicaram remoção significativa do fármaco, atingindo valores de até $87 \%$ em meio neutro ( $\mathrm{pH}$ 7) utilizando radiação UV-visível. Este composto bioorgânico possui importante fração de grupos aromáticos, o que favorece sua atividade fotoquímica. De fato, o experimento realizado em meio anóxico, bem como resultados da literatura, evidencia a participação de oxigênio singlete como principal espécie oxidante. Dessa forma, o BOS C pode ser empregado como promotor da fotólise tendo em vista 0 tratamento sob baixas potências radiantes ou sob radiação solar de águas contaminadas com o antibiótico, o que é uma vantagem operacional. Os BOS, que possuem estrutura similar à da matéria orgânica natural presente em águas superficiais, representam assim uma alternativa interessante para promoção de processos fotolíticos e foto- 
oxidativos de poluentes. Nesse sentido, sugere-se a realização de experimentos sistemáticos na presença de BOS C e luz solar. Recomenda-se também a determinação da concentração ótima de BOS em relação à concentração do fármaco.

Por outro lado, a degradação da ENRO pelo processo $\mathrm{H}_{2} \mathrm{O}_{2} / \mathrm{UV}$ apresentou resultado medianamente satisfatório, sendo o máximo de remoção do fármaco de $48 \%$ em pH 7. $\mathrm{O}$ processo $\mathrm{H}_{2} \mathrm{O}_{2} / \mathrm{UV}$ na presença de $\mathrm{BOC} \mathrm{C}$ apresentou resultado muito inferior ao esperado, o que sugere que a ação de oxigênio singlete e/ou radicais hidroxila frente à enrofloxacina seja prejudicada na presença de peróxido de hidrogênio em ambos os pH. 


\section{SUGESTÕES PARA TRABALHOS FUTUROS}

Uma possibilidade interessante, variar a concentração de $\mathrm{H}_{2} \mathrm{O}_{2}$ a fim de verificar o comportamento do fármaco frente ao peróxido.

Outra possibilidade interessante, a ser avaliada em trabalhos futuros, é o emprego de BOS na estabilização de espécies de ferro em solução aquosa, o que pode permitir, por exemplo, o processo foto-Fenton $\left(\mathrm{H}_{2} \mathrm{O}_{2}-\mathrm{Fe}(\mathrm{III}) / \mathrm{UV}\right.$ visível) em meio neutro e levemente básico. 


\section{REFERÊNCIAS BIBLIOGRÁFICAS}

ALMEIDA, G. A.; WEBER, R. R. Fármacos na Represa Billings. Universidade de São Paulo - Instituto Oceanográfico Praça do Oceanográfico, 191 - CEP 05508-900 Cidade Universitária - São Paulo - SP.

ALLERA, A. Sviluppo e Caratterizzazione di Materiali Magnetici Ibridi per Abbatimento di Inquinanti in Soluzione. Università degli Studi di Torino Torino-Itália, 2012.

ANDREOZZI R., CAPRIO V., INSOLA A., MAROTTA R. Advanced Oxidation Processes (AOP) for Water Purification and Recovery. Catal. Today, v.53, p.51-59, 1999.

ANDREOZZI, R.; D'APUZZO, A.; MAROTTA, R. A. Oxidation of aromatic substrates in water/goethite slurry by means of hydrogen peroxide. Water Res., v.26, p.4691-4698, 2002.

ANVISA Disponível em <anvisa.gov.br> acesso em>16 nov. 2012.

BAALOUSHA, M., MOTELICA-HEINO, M.; LE COUSTUMER, P. Conformation and size of humic substances: Effects of major cation concentration and type, $\mathrm{pH}$, salinity and residence time, Colloids and Surfaces A: Physicochem. Eng. Aspects, v. 272, p. 48-55, 2006

BÉLTRAN, F. J.; GONZÁLEZ, M.; GONZÁLEZ J.F. Industrial wastewater advanced oxidation. part I. UV radiation In the presence and absence of hydrogen peroxide. Water Res., v.31, p.2405-2414, 1997.

BILA, D.M.; DEZOTTI, M. Fármacos no meio ambiente. Química Nova, v.26, p.523-530, 2003.

BOSSMANN, S. H.; OLIVEROS, E.; GOB, S.; SIEGWART, S.; DAHLEN, E.P.; PAYAWAB JR, L.; STRAUB, M.; WORNER, M.; BRAUN, A. M. New evidence against hydroxyl radicals as reactive intermediatesin the thermal and photochemically enhanced fenton reactions. J. Phys. Chem. A, v.102 p.5542-5550, 1998.

BOXALL, A.B.A.; FOGG, L.; BLACKWELL, P.A.; KAY, P. \& PEMBERTON, E.J. Review of veterinary medicines in the environment. R\&D Technical Rep., p.251, 2002. 
BROWN, K.D.; KULIS, J.; THOMSON, B.; CHAPMAN, T.H.; MAWHINNEY D.B. Occurrence of antibiotics in hospital, residential, and dairy effluent, municipal wastewater, and the Rio Grande in new Mexico. Sci. Total Environ., v.366, p.772-783, 2006.

BUGYEI, K.; BLACK, W.D.; MCEWEN, S. Pharmacokinetics of enrofloxacin given by oral, intravenous and intramuscular routes in broiler chickens. Can. J. Veter. Res., v. 63: p.193-200, 1999.

CANONICA, S.; FREIBURRGHAUS, M. Electron-rich phenolsfor probing the photochemical reactivity of freshwaters. Environ. Sci. Technol., v.35, p.690-695, 2001.

CARBALLA, M.; OMIL, F.; LEMA, J. M.; LLOMPART, M.; GARCÍA-JARES, C.; RODRÍGUEZ, I.; GÓMEZ, M.; TERNES, T.; Biosurfactants from Urban Green Waste. Water Res., v.38, p.2918, 2004.

CHEMICALIZE. Disponível em <www.chemicalize.com.br> acesso em> 25 mar. 2013.

CRISTINO, W. Tratamento de efluentes têxtil contendo corante reativo violeta 5: comparação entre os processos oxidativos avançados irradiados e não irradiados. Engenharia de Processos Químicos - Escola de Engenharia Mauá do Centro Universitário do Instituto Mauá de Tecnologia, São Caetano do Sul, p.136, 2006.

CUNHA, R. L.; OLIVEIRA, S. C.; JUNIOR, A. M. Estudo da degradação de medicamentos da classe dos quimioterápicos pelo processo Foto-Fenton. Universidade Federal do Mato Grosso do Sul, 2009.

DOMĖNECH, X., JARDIM, W. F., LITTER, M. I. Procesos avanzados deoxidación para la eliminación de contaminantes. In: Eliminación de contaminantes por fotocatálisis heterogenea. Rede Cyted, La Plata, cap. 1, 2001.

EICKHOFF, P.; HEINECK, I.; SEIXAS, L. J. Gerenciamento e destinação final de medicamentos: uma discussão sobre o problema. Revista Bras. Farm., Rio Grande Do Sul, v.90, p.64-68, 2009. 
ENVIRONBOS, Isolation, Characterization and Screening of Environmental Applications of Bio-Organic Substances Obtained from Urban Biomasses. R\&D Technical Report, Project FP7-PEOPLE-2010-IRSESComissão Europeia, 2013.

ESPLUGAS, S.; G. J., CONTRERAS, S.; PASCUAL, E.; RODRÍGUEZ, M. Comparison of different advanced oxidation processes for phenol degradation. Water Res., v.36, p.1034-1042, 2002.

GARBIN J. R., MILORI D. M. B. P., SIMÕES M., DA SILVA W. T. L., NETO L. M.; Avaliaçao do efeito catalisador de substâncias húmicas na fotodegradação dos herbicidas imazaquin e atrazina. Chemosphere, v.66, p.1692-1698, 2007.

GARTISER, S.; URICH, E.; ALEXY, R.; KÜMMERER, K. Ultimate biodegradation and elimination of antibiotics in inherent tests. Chemosphere, v.67, p.604-613, 2007.

GOI, A.; TRAPIDO, M. Hydrogen peroxide photolysis, Fenton reagent and photo-fenton for the degradation of nitrophenols: a comparative study. Chemosphere, v.46, p.913-922, 2002.

GUINEA, E.; GARRIDO, J. A.; RODRÍGUEZ, R. M.; CABOT, P. L.; ARIAS, C.; CENTELLAS, F.; BRILLAS, E. Degradation of the fluoroquinolone enrofloxacin by electrochemical advanced oxidation processes based on hydrogen peroxide electrogeneration. Eletrochimica Acta, v.55, p.2101-2115, 2010.

GULKOWSKA, A.; HE, Y.; SO, M.K.; YEUNG, L.W.Y.; LEUNG, H.W.; GIESY, J.P.; LAM, P.K.S.; MARTIN, M.; RICHARDSON, B.J. The occurrence of selected antibiotics in Hong Kong coastal waters. Marine Poll. Bull., v.54, p.1287-1306, 2007.

HEBERER T. Occurrence, fate, and removal of pharmaceutical residues in the aquatic environment: a review of recent research data. Toxicol. Lett., v.131, p.5-17, 2002.

HUANG, C.P.; DONG, C.; TANG, Z. Advanced chemical oxidation: Its presente role and potential future in hazardous waste treatment. Waste Manag., v.13, p.361-377, 1993. 
IKEHATA, K.; NAGHASHKAR, N.J.; EL-DIN, M.G. Degradation of aqueous pharmaceuticals by ozonation and advanced oxidation processes: a review. Ozone Sci. Technol., v.28, p.353-414, 2006.

ISIDORI, M.; LAVORGNA, M.; NARDELLI, A.; PARRELLA, A.; PREVITERA, L.; RUBINO, M. Ecotoxicity of naproxen and its phototransformation products. Sci. Total Environ., v.348, p.93-101, 2005.

JUNIOR, I. S. N. Determinação seletiva de fluoroquinolonas por fosforimetria na temperatura ambiente em substrato de celulose com nitrato de tório. Pontifícia Universidade Católica do Rio de Janeiro, 2007.

KHODJA A. A., TRUBETSKAYA O., TRUBETSKOJ O., CAVANI L., CIAVATTA C., GUYOT G., RICHARD C.; Compositional differences between soil humic acids extracted by various methods as evidenced by photosensitizing and electrophoretic properties. Chemosphere, v. 62, p. 1021-1027, 2006.

KÜMMERER, K. Drugs in environment: emission of drugs, diagnosticaids and disinfectants into wastewater by hospitals in relation to other sources. A Review. Chemosphere, v.45, p.957-969, 2001.

KÜMMERER, K. Significance of antibiotics in the environment. J. Antimicrob. Chemother., v. 52, p.5-7, 2003.

LEGRINI, O.; OLIVEROS, E.; BRAUN. A. M. Photochemical processes for water treatment. Chemosphere Rev., v. 93, p.671-698, 1993.

LESHER, G. Y.; GRUETT M. D.; FROELICH, E. J., 1,8-Naphthyridine Derivates - A new class of chemotherapeutic agents. J. Medic. Pharm. Chemosphere, v.5, p.1063, 1962.

MACK, J. E.; BOLTON, J.R. Photochemistry of nitrite and nitrate in aqueous solution: a review. J. Photochem. Photobiol. A: Chemosphere, v.128, p.1-13, 1999.

MALCOM R. L. In Humic substances II: in search of the structure. Wiley Intersc., New York, p.339-372,1989. 
MELLO, S. A. S.; TROVÓ G.T.; BAUTITZ I. R.; NOGUEIRA R. F. P. Degradação de fármacos residuais por processos oxidativos avançados. Química Nova, v.32, p.188-197, 2009.

MITCHELL, M. A. Therapeutic review enrofloxacin, J. Exotic Pet. Med., v.15, p.66-69, 2006.

MONTONERI, E. V.; BOFFA, P.; SAVARINO, D.G.; PERRONE, G.; MUSSO, MENDICHI R.; M.R. CHIEROTTI, R.; GOBETTO, Humic Acid-like matter isolated from green urban wastes. Part I: Structure and Surfactant properties. Chemosphere Sus., v 2, p.239 -247, 2009.

MONTONERI, E., SAVARINO, P., BOTTIGLIENGO, S., MUSSO, G., BIANCO PREVOT, A., FABBRI, D AND PRAMAURO, E. Humic acid-like matter isolated from green urban wastes Part II: Performance in chemical and environmental technologies. Bioresources submitted for publication, 2007.

NAKAJIMA A., TAHARA M., YOSHIMURA Y., NAKAZAWA $H$. Determination of free radicals generated from light exposed ketoprofen. Photochem. Photobiol. A, v.174, p.89-97, 2005.

NASCIMENTO, C. A. O, TEIXEIRA, A. C. S. C., GUARDANI, R., QUINA, F. H., LOPEZ-GEJO, J. Degradacion fotoquimica de compuestos orgânicos de origen industrial. In Química Sustentable En Lationo america, N. Nudelman, Editora De La Universidad Nacional Del Litoral, Santa Fe, Argentina; p.205-220, 2004.

NEYENS, E., BAEYENS, J. A Review of classic Fenton's peroxidation as na advanced oxidation technique. J. Haz. Mat. B, v.98, p. 33-50, 2003.

OU X., QUAN X., CHEN S., ZHAO H., ZHANG Y.; A trazine photodegradation in aqueous solution induced by interaction of humic acids and iron: photoformation of iron(II) and hydrogen peroxide. J. Agric. Food Chem, v.55, p. 8650-8656, 2007.

PÉREZ M., TORRADES F., DOMÉNECH X., PERAL J. Fenton and photoFenton oxidation of textile effluents. Water Res., v.36, p.2703-2710, 2002.

PIGNATELLO, J. J.; OLIVEROS, E.; MACKAY, A. Advanced oxidation processes for organic contaminant destruction based on the fenton 
reaction and related chemistry. Crit. Rev. Environ. Sci. Technol., v.36, p.1-84, 2006.

PISTOS, C.; TSANTILI-KAKOULIDOU, A.; KOUPPARIS, M. Investigation of the retention/ph profile of zwitterionic fluoroquinolonas in reversedphase and ion-interaction high performance liquid chromatography. J. Pharm. Biom. Anal., v.39, p.438-443, 2005.

PONEZI, A.N. et al. Fármacos em matrizes ambientais - revisão, Campinas: Centro Pluri disciplinar de Pesquisas Químicas, Biológicas E Agrícolas (Cpqbaunicamp), p.11, 2006.

PREVOT, B. A; FABBRI D.; PRAMAURO E.; BAIOCCHI C.; MEDANA C., Sensitizing effect of bio-based chemicals from urban wastes on the photodegradation of azo-dyes. Chromat., v.1202, p.145-154, 2008.

QUAGLIOTTO, P.; MONTONERI, E.; TAMBONE, F.; ADANI, F.; GOBETTO, R.; VISCARDI, G.; Chemicals from Wastes: Compost-Derived Humic Acid-like Matter as Surfactant Environ. Sci. Technol., v.40, p.16861692, 2006.

REGITANO J. B.; LEAL R.M.P. Comportamento e impacto ambiental de antibióticos usados na produção animal brasileira. Performance and environmental impact of antibiotics in animal production in Brazil. Rev. Bras. Ciênc. Solo, v.34, n.3, 2010.

ROCHA, D. P. et al. Coordenação de metais a antibióticos como estratégia de combate à resistência bacteriana. Química Nova, v.34, p.111$118,2011$.

SAFARZADEH-AMIRI, A.; BOLTON, J. R.; CARTER, S. R. The use of iron in dvanced oxidation processes. J. Adv. Oxid. Technol., v.1, p.18-26, 1996.

SARMAH, A.K.; MEYER, M.T. \& BOXALL, A.B.A. A global perspective on the use, sales, exposure pathways, ocurrence, fate and effects of veterinary antibiotics (vas) in the environment. Chemosp., v. 65, p.725-759, 2006.

SENESI N., LOFFREDO E. in Biopolymers: lignin, humic substances and coal, Wiley-VCH, Weinheim, Germany, p. 248-273, 2001 
SCHULTEN, H. R.; SCHNITZER, M.; A state of the art structural concept for humic substances, Naturwissenschaften, v. 80, p.29-30, 1993.

SOUSA, I. C. S. C. Interação da enrofloxacina com modelos biomembranares: influência das suas propriedades físico-químicas. Faculdade De Ciências Da Universidade Do Porto. Departamento de Química. Licenciada em Química (Fcup), p.25-26, 2007.

STURINI; ET AL., 2010 M. STURINI, A.; SPELTINI, F.; MARASCHI, A.; PROFUMO, L. PRETALI, E.; FASANI, A.; Albini photochemical degradation of marbofloxacin and enrofloxacin in natural waters. Environ. Sci. Technol., v. 44, p. 4564-4569, 2010.

VASCONCELOS, D. V.; GOMES, A. Tratamento de efluentes de postos de combustíveis para o reúso usando processos oxidativos avançados. Caderno Unifoa, v.11, p.35-46. 2009.

WANG, P.; HE, YL.; HUANG, $\mathrm{CH}$. Oxidation of fluoroquinolone antibiotics and structurally related amines by chlorine dioxide: reaction kinetics, product and pathways evaluation. Water Res., v.44, p.5989-5998, 2010.

YANG LI, JUNFENG NIU, WENLONG WANG; Photolysis of enrofloxacin in aqueous systems under simulated sunlight irradiation: Kinetics, mechanism and toxicity of photolysis products. Chemosphere, p.892-897, 2011.

ZEPP, R.G.; HOIGNÉ, J.; and BADER, H.; Nitrate-induced photooxidation of trace organic chemicals in water. Environ. Sci. Technol., v.21, p.443-449, 1987. 